Bryn Mawr College

Scholarship, Research, and Creative Work at Bryn Mawr College

Classical and Near Eastern Archaeology Faculty

Research and Scholarship

Classical and Near Eastern Archaeology

2014

\title{
A Type $\gamma$ Courting Scene for Alan: The Spitzer Amphora at Bryn Mawr College
}

Robert F. Sutton

Bryn Mawr College

Let us know how access to this document benefits you.

Follow this and additional works at: http://repository.brynmawr.edu/arch_pubs

Part of the History of Art, Architecture, and Archaeology Commons

\section{Custom Citation}

R. Sutton, "A Type $\gamma$ Courting Scene for Alan: The Spitzer Amphora at Bryn Mawr College," in Ed. A. Avramidou and D. Demetriou, Approaching the Ancient Artifact: Representation, Narrative, and Function; A Festschrift in Honor of H. Alan Shapiro. Berlin: De Gruyter, 2014.319-334.

This paper is posted at Scholarship, Research, and Creative Work at Bryn Mawr College. http://repository.brynmawr.edu/arch_pubs/161

For more information, please contact repository@brynmawr.edu. 


\section{Approaching the Ancient Artifact}

Representation, Narrative, and Function A Festschrift in Honor of $\mathrm{H}$. Alan Shapiro

Edited by

Amalia Avramidou and Denise Demetriou

\section{DE GRUYTER}


ISBN 978-3-11-030873-0

e-ISBN 978-3-11-030881-5

\section{Library of Congress Cataloging-in-Publication Data}

A CIP catalog record for this book has been applied for at the Library of Congress.

\section{Bibliographic information published by the Deutsche Nationalbibliothek}

The Deutsche Nationalbibliothek lists this publication in the Deutsche Nationalbibliografie; detailed bibliographic data are available on the Internet at http://dnb.dnb.de.

(C) 2014 Walter de Gruyter GmbH, Berlin/Boston

Cover image: bpk | RMN - Grand Palais | Hervé, Lewandowski

Typesetting: jürgen ullrich typosatz, Nördlingen

Printing: Hubert \& Co. GmbH \& Co. KG, Göttingen

@) Printed on acid-free paper

Printed in Germany

www.degruyter.com 


\section{Table of Contents}

Acknowledgements - V

Contributors - XI

Abbreviations $-\mathbf{X V}$

Amalia Avramidou and Denise Demetriou

Foreword - XVII

H. Alan Shapiro: Bibliography $-\mathbf{X I X}$

\section{Myth into Art}

Sarah P. Morris

Helen Re-Claimed, Troy Re-Visited: Scenes of Troy in Archaic Greek Art - 3

Beth Cohen

Polyxena's Dropped Hydria: The Epic Cycle and the Iconography of Gravity in Athenian Vase Painting - 15

Tyler Jo Smith

Myth into Art: A Black-figure Column Krater from Castle Ashby at the University of Virginia — 31

J. Michael Padgett

The Serpent in the Garden: Herakles, Ladon, and the Hydra - 43

Heide Mommsen

Reflections on Triton -53

Erika Simon

Herakles and Geras in Etruria — 65

Ralf von den Hoff

Theseus and Aithra! A Forgotten Fragment and an Old Problem - 69

Mario lozzo

Theseus and Periphetes by the Sabouroff Painter? - 77

Marcello Barbanera

Dressing to Hunt. Some Remarks on the Calyx Krater from the So-called House of C. Julius Polybius in Pompeii -91 
Michalis Tiverios

Phrixos' Self-sacrifice and his "Euphemia” — 105

Stephan Steingräber

Philoktetes in Brauron (Attica) and Volterra (Etruria) - 117

Susan Rotroff and Robert Lamberton

The Tombs of Amazons - 127

\section{Iconography of Mourning}

Susan B. Matheson

The Wretchedness of Old Kings — 141

Judith M. Barringer

Athenian State Monuments for the War Dead: Evidence from a Loutrophoros — 153

Wendy E. Closterman

Women as Gift Givers and Gift Producers in Ancient Athenian Funerary Ritual — 161

Matthew Roller

Volgei nescia: On the Paradox of Praising Women's Invisibility - 175

Dietrich Boschung

Reduced Myths: Roman Ash Chests with Mythological Scenes — 185

John H. Oakley

Roman Sarcophagi in the Toledo Museum of Art -197

\section{Art and Cult}

Monika Trümper

Bathing in the Sanctuaries of Asklepios and Apollo Maleatas at Epidauros - 211

Olga Palagia

The Three Graces at the Panathenaia - 233

Lina Kokkinou

Hermes and the Athenian Acropolis: Hermes Enagonios (?) on a Red-figure Miniature Amphora of Panathenaic Shape by the Bulas Group — 243 
Nassi Malagardis

'Av $\alpha \theta \dot{n} \mu \alpha \tau \alpha$ on the Athenian Acropolis and in the Sanctuary of the Nymph (600-560 BCE): The Case of the Skyphoi — 255

\section{Guy Hedreen}

The Artificial Sculptural Image of Dionysos in Athenian Vase Painting and the Mythological Discourse of Early Greek Life — 267

\section{Allison Surtees}

Satyrs as Women and Maenads as Men: Transvestites and Transgression in

Dionysian Worship — 281

\section{Courtship Scenes}

Dyfri Williams

“To Dream the Impossible Dream" — 297

Jenifer Neils

Hare and the Dog: Eros Tamed — 311

Robert F. Sutton

A Type y Courting Scene for Alan: The Spitzer Amphora at Bryn Mawr College - 319

Adrienne Lezzi-Hafter

A Lazy Afternoon — 335

\section{Narrative Strategies}

J. Robert Guy

A Matter of Style/Why Style Matters: A Birth of Athena Revisited — 341

Jasper Gaunt

Story and Status: The François Vase and the Krater from Vix — 349

Bettina Kreuzer

A Frame for Names: The Case of the Hydria Louvre F $287-363$

Mark D. Stansbury-O’Donnell

Composition and Narrative on Skyphoi of the Penelope Painter - 373 
Martin Langner

Where Should We Place the Krater? An Optimistic Reconstruction of the Vessel's Visibility during the Symposion - 385

Helene A. Coccagna

Manipulating Mastoi: The Female Breast in the Sympotic Setting — 399

Christoph Reusser and Martin Bürge

Laconian Wine - 413

Deborah Lyons

Arion the Methymnian and Dionysos Methymnaios: Myth and Cult in Herodotus' Histories -425

Clemente Marconi

The Mozia Charioteer: A Revision — 435

Carlos A. Picón

An Ancient Plaster Cast in New York: A Ptolemaic Syncretistic Goddess — 449

Claudia Zatta

The Non-Human Paradox: Being Political in Aristotle’s Zoology — 455

Ch. Brian Rose

Are We Rome? - 467

Bibliography - 483

Index - 539

Color Plates $-\mathbf{5 6 9}$ 


\section{A Type y Courting Scene for Alan: The Spitzer Amphora at Bryn Mawr College}

I met Alan Shapiro in 1974 in Athens and quickly discovered a common interest in iconography and vase painting. I am delighted to present here an amphora reflecting our shared enthusiasm for the social interpretation of Attic vase paintings, one of the finer pieces in the small collection of antiquities the late Doreen Spitzer assembled in her youth and bequeathed to her alma mater Bryn Mawr College (color figs. 38, 39; figs. 1, 2). ${ }^{1}$ One side depicts a procession of gods, the other presents pederastic sexual congress among nude male dancers.

\section{Description}

The vase is complete except for chips and surface spalls that had been hidden by restoration; it was accidentally broken and was recently dissembled and cleaned pending full restoration. The shape is a small, well-proportioned standard black-figure neck amphora, ${ }^{2}$ and the painter has made extensive use of added white and red to create an attractive four-color pattern that enhances the form's elegant play of positive and negative space. The echinus mouth is black with reserve upper surface. An attenuated lotus and palmette band decorates the neck, and a slight raised molding marks the transition to the shoulder. The body is decorated in black figure, and a red ring marks the transition to the black disk foot. Black handles in three rolls connect the neck to the shoulder. Like other standard neck amphoras, the lower body is decorated with three increasingly shorter bands that spread organically up from the solid base and run completely around the body: long, slender rays below, tighter, more compact lotus-bud chain above, and crowned by a low, simple running meander that supports thin groundlines for the figures. The body above and the neck are divided into two sides by the handles and long looping palmette tendrils with buds. These florals, conceived as the landscape or architecture of the vase, are overlapped by the figures at either end of side $\mathrm{B}$. The figures extend over the full height of the upper body, their heads

1 Bryn Mawr College Art and Artifact Collections, 2011.17.2, gift of Doreen Canaday Spitzer, Class of 1936. Height: $32 \mathrm{~cm}$; diameters: mouth $14.5 \mathrm{~cm}$, base: $11 \mathrm{~cm}$. http://Triarte.brynmawr.edu and http:// emuseum.net; rotating color image at http://triarte.brynmawr.edu/media/images/2011.17.2_BMC_ spin.mov (accessed 6/12/2013). Thanks to Marianne Weldon, Joelle Collins, and Camilla McKay at Bryn Mawr; in Athens, to Christina Avronidaki at the National Archaeological Museum and Angelos Zarkadas at the Canellopoulos Museum; to Lucilla Burn and Timothy McNiven; and to the editors.

2 Moore/Philippides 1986, 7-12, esp. 11-12. 
Fig. 1: Cat. No. 25, detail, Side A. Artemis and Apollo. Poseidon on left. As color fig. 38. Photo: author.

curving back onto the slightly sloping shoulder. A short band of alternating black and white tongues crowns the shoulder on each side. The division into two sides is marked emphatically at the neck by the intervening handles, while the lip spreading above balances the base in reasserting the unity of the vessel. Both sides are decorated with axial compositions in which the central subject appears between framing figures.

Side A (color fig. 38) illustrates a procession of gods whose otherworldly music resonates on side B. In the center (fig. 1) Apollo stands or slowly advances right playing the kithara, his usual instrument in black figure. ${ }^{3}$ He is partly covered by a woman holding a sprig who is surely his sister Artemis. ${ }^{4}$ The siblings are framed by

3 Bundrick 2005, 18-21; cf. LIMC II (1984) 199-213 pls. 190-203, s.v. Apollon (W. Lambrinoudakis).

4 Cf. the overlapping pair on BAPD 301798, with Artemis identified by a deer. 
Fig. 2: Cat. No. 25, detail, Side B. As color fig. 39. Photo: author.

two bearded gods who move away, but turn their heads back toward the central group. Hermes, with a slender caduceus, leads the procession, while Poseidon, with a similarly attenuated trident, almost a staff with trident finial, seems to head off in the other direction, or possibly dances, waving a salutation. Their clothing is lavishly decorated with white dots and incised embroidery in addition to red and black folds. Apollo and Artemis are formally arrayed in long chitons and himatia, while Poseidon wears a shorter cloak over a tunic, of which only the upper border at the neck is indicated. Hermes' cloak is even shorter, covering both shoulders, without a tunic, and he wears his usual winged shoes and Robin Hood cap. All gods are longhaired, with Hermes' looped up behind in a krobylos. Artemis is crowned with a red headband, and Apollo with a black leafy laurel wreath emerging over his brow. The framing gods are bearded, while Apollo is a full-grown, beardless youth, a bit shorter than his sister. She has mature breasts and incised muscles on her white right forearm. Apollo strums the kithara with a plectrum in his right hand and mutes the strings with his left. The instrument has a rectangular base decorated with incised loops, like those on his hem, and circles with a line of white dots, and long arms with white (ivory?) tips and snake volute supports inside. 
Side B (color fig. 39) shows a pederastic courting scene of Beazley's Type $y .{ }^{5}$ In the center a youthful eromenos and bearded erastes peform sexual intercourse in the dia merion mode (fig. 2) framed by pairs of naked men dancing in from either side. The adult erastes hunches over with bent knees and stares downward intently, holding the youth tightly between his thighs and embracing him with hands clenched on the boy's hips. He is slightly wilder than his dancing companions, with a large eye, an odd, almost satyric ear, and a slightly longer beard made a bit shaggy by short incisions, like the hair above his neck. The eromenos stands upright, looking ahead over his lover's shoulder, and reaches back awkwardly across his lover's upper right arm with clenched fist, his other, bent arm only partly shown. Like Apollo, he sports the long hair of youth and rises slightly above the older men. He wears a short cloak that must be open in front but hangs behind him to cover his buttocks and pass between his body and arms on either side, its ends hanging free on either side. It has red folds like those on the other side, and is decorated with a few white dot clusters; an incised fold shows that it covers his back and sides down to the knees.

The naked dancers appear in profile, with partly incised red beards, red circles around their nipples, and a range of hairstyle. The two on left have short hair with red crests in front, with traces of a red hairband on the leftmost figure, and small flaccid genitals. The leftmost dancer stands or prances on one leg, raising the other behind, and appears to slap his companion on the buttocks, although a slight bit of reserve may indicate that his hand is closed and passes behind. His companion stands with slightly flexed knees, raising his hands up and down, recalling Type $\beta$ courting; he may be a bit younger, less muscular than his companion, slightly paunchy, with sagging horizontal abdominals, vague musculature on his left arm, but well defined leg muscles. On right, the leading dancer moves in vigorously with flexed, widely spaced knees, his left hand lowered in front, the other raised and bent oddly behind, its hand emerging behind his shoulder, vaguely echoing the dancer on left; his long hair flows behind onto his shoulders, his red beard is fringed, and an incised pompadour rises over his forehead. The remaining dancer stands in place twisting his torso to a frontal view, raising his left arm behind and over his head, the other arm lower, crossing his waist. He lacks a defined mouth and also sports an elaborate pompadour with very short krobylos.

\section{Attribution and Date}

This amphora can be attributed to the Medea Group, a small group of standard neck amphoras and a few Type B amphoras that have been dated around 530-520 BCE. In 1945 H. R. W. Smith attributed four small neck amphoras to the Medea Painter. ${ }^{6}$ Sir

5 Lear/Cantarella 2008, 206 no. 3.49.

6 Smith 1945, 473. 
John D. Beazley retained the name but recognized instead a Group that others have subsequently expanded. ${ }^{7}$ The Spitzer amphora has the small shape and proportions of the Group's standard neck amphoras with low spreading mouth, and shares details of ornament with most, especially the slender rays above the base, disposition of buds, and shape of the five-petaled handle palmettes. ${ }^{8}$ The form of Apollo's lyre is virtually identical to that on a neck amphora in London; they share the idiosyncratic drawing of Apollo's right forearm, hand, wrist, and intersecting incised muscle, and must be by the same painter. ${ }^{9}$

\section{Iconography}

Side B belongs to a group of pederastic courting scenes that Beazley presented orally in 1947 and published the following year. ${ }^{10}$ In Type $\alpha$ the male wooer (erastes) reaches for the chin and genitals of a courted boy or youth (eromenos) in the "up and down" position. In Type $\beta$ one or both of them holds a cock or other love gift (see Neils in this volume). In Type $\gamma$, as Beazley writes, "The moment depicted is later than in Types $\alpha$ and $\beta$, and the two figures are interlocked." He carefully details and analyzes the visual and archaeological data with polite discretion, leaving much unspoken. Thirty years later Sir Kenneth Dover said it all. ${ }^{11}$ Although literary texts regularly describe pederastic anal intercourse, it was highly stigmatized (as in the common insult katapugon). ${ }^{12}$ Dover recognized that the preference of vase painters to portray pederastic lovemaking in the Type $y$ dia merion mode (which he termed "intercrural"), served to idealize pederasty. He argued that this mode of intercourse preserved the manly reputation of the eromenos by avoiding penetration and assimilation into a woman; one might also suggest that, since the anus is the organ of defecation, anal intercourse may also have been regarded as inherently unclean and polluting. Yet, pederasty was often idealized in antiquity (and later), invested with a pedagogical role in contributing to male Bildung, reflected in vase paintings through reference to hunting, cockfighting, and other character-building manly activities. ${ }^{13}$

7 ABV 321.1-4 and another near; Para 141; Add ${ }^{2}$ 87; additions in CVA Getty 1, 28; BAPD 4, 7037, 7142, 10152, 28120, 43275, 301682-301686, 351042-351044, 9024502.

8 E.g., in Smith's list BAPD 301362; Buitron-Oliver 1972, 50-51 no. 20, http://museums.fivecolleges. edu/detail.php?museum=ac\&t=objects\&type $=$ all $\& f=\& s=1950.59 \&$ record $=0 \quad$ (accessed 6/15/13) and BAPD 301683-301684; the Medea vase BAPD 301685 (A with wrong image) has fuller seven-petal palmettes.

9 BAPD 301684 (on Smith's list), with unusual neck pattern.

10 Beazley 1989b, 3-25, 40; n. 10 lists earlier work.

11 Dover 1978, on vases esp. 4-9, 91-100, 205-225.

12 Dover 1978, 142.

13 Koch-Harnack 1983; Schnapp 1997, esp. Chapter 4, 123-127; critically Lear/Cantarella, 2008, esp. 72-105; cf. Dover 1978, 185-203. 
The flood following Dover has provided nuance and challenged various points, even rejecting "homosexuality" as a valid concept in pre-modern settings. ${ }^{14}$ Alan Shapiro's work remains among the best, remarkable for its sensitive mastery of visual, verbal, and historical evidence. ${ }^{15}$ Andrew Lear's recent book with Eva Cantarella represents the most nuanced treatment of the iconography including a corpus assembled by the late Keith DeVries that extends far beyond courting. ${ }^{16}$

To set the Spitzer amphora in context, I present a catalog below arranged by vase shape of thirty-six black-figure Attic vases illustrating Type $y$ courting. This corpus confirms that vase paintings showing the dia merion mode idealize pederasty and invest the eromenos with dignity. Many include manly pedagogic and other elements shared with Types $\alpha$ and $\beta$ while confirming Lear's observation that Type $y$ scenes are somewhat removed from the courting Types $\alpha$ and $\beta$; yet, like heterosexual lovemaking scenes, they are more closely connected to the dance and komos, ${ }^{17}$ sometimes linked specifically to Dionysos $(11,26,29,9$ ?). I retain a vexing scene by the Gela Painter requiring discussion elsewhere (32), in which the eromenos lacks genitals and may be female, as Angelos Zarkadas believes. ${ }^{18}$

Discussion is synchronic by compositional type, not evolutionary. The group is largely restricted to the second half of the sixth century, with few securely dated before ca. 550 and perhaps some after ca. $500 \operatorname{BCE}(29,31,32,36)$. The couples show little variation apart from placing the erastes on right or left, apparently without significance. When it can be determined, the erastes is bearded, except on 36 and 29; the eromenos is never bearded. The scenes cannot be regarded at face value as objective depictions of social reality. Like heterosexual lovermaking, ${ }^{19}$ Type $y$ is set in the company of others. Black-figure lovemaking is ritualized as a public display or performance; in life, sexual intercourse was private. ${ }^{20}$

Beazley inserts a damaged Siana cup tondo, dated ca. 570-545 BCE, between courting Types $\beta$ and $y$ that he must have regarded as a proto-y scene: an isolated couple with fighting cock (as in Type $\beta$ ) embraces but probably did not achieve consummation. ${ }^{21}$ Type $y$ appears around the middle of the sixth century. In tondos, the couple is framed by single dancers, and the figures are often festooned with

14 Impossible to cover here; see Halperin 2002, with partial palinode.

15 Shapiro 1981b, 1992a, 2000, and 2012b.

16 Lear/Cantarella 2008, Appendix, poorly integrated with the text. DeVries 1997 is his only publication using the corpus.

17 See Smith 2010, Chapters 3 and 4, esp. 108-117.

18 The eromenoi look nothing like the courted woman on the painter's lekythos Moore/Philippides 1986, no. $871 \mathrm{pl}$. 79. In several other scenes genitals of either eromenos or erastes were omitted or have worn off. I am grateful to Dr. Angelos Zarkadas for permitting close examination pending his forthcoming publication in CVA.

19 Sutton 2009.

20 Sutton 2000, 182-184.

21 Copenhagen 5180; Beazley 1989b, 18; Lear/Cantarella 2008, 196 no 1.5; BAPD 300624. 
wreaths or garlands, indicating festivity (1, 2, probably 3, and 4). In two other tondos, the dancers are replaced by a pair of hunting dogs (5) and hare and dog (6) that run up the frame emulating the bipedal dancers. Twice inscriptions name the lovers $(4,5)$. In the tondo of a Dionysian eye cup (11), the dancers become a man pursuing a boy, with vines of Dionysos and a hunting dog.

In non-circular formats nude male dancers and other figures frame the couple; a preference for two dancers per side is not determined by available space, since they may be spread out (14) or compacted $(16,17,29)$. On the Hermogenean skyphos (14) one dancing youth displays an erection, but this is exceptional, and these dancers are restrained, especially in contrast to Tyrrhenian komasts or the masturbators who sometimes frame heterosexual lovers. ${ }^{22}$ On a patch band cup from Chiusi (10) a bearded man holding two wreaths dances away. Single dancing youths frame the couple on a lekythos (30) and one side of a type A cup (12), and dancing men appear on an amphora (19). The cup's other side (12) is asymmetrical, with two wreathed youths to the right of the lovers, and a single youth on left; the converse also appears, two dancing men to left of the lovers, and a single man on right (22). Most often two dancers frame each side: nude youths $(14,15,27)$; nude youth and woman in dress (8); nude men (20, 25 [Spitzer amphora]). On an amphora (17) two nude dancing youths are framed by draped figures, a man on left and youth on right, the latter initiating courting. Two lekythoi have more dancers, including clothed, ivy-wreathed women draped in animal pelt (nebris) of the Dionysian realm, with elements of the other courting types. The Taleides Painter (26) shows three dancers on left, including a man, a woman in nebris, and a youth holding out an aryballos to the eromenos, probably offering lubricant, and on right, a youth with a lyre leads the way and another holds a game cock. The second (29) is more unusual, crowded with nine framing figures, including at least three women in nebris and a nude Type $\alpha$ erastes with an extremely pointed chin, surely indicating a short beard, who initiates courting as if another Type y erastes - beardless and longhaired - were not already in place, and caresses the face of the short haired eromenos, reaching towards his hidden genitals. If he were initiating a threesome and hoping to perform simultaneous anal intercourse with the erastes already in situ, one might expect attention directed to the latter's buttocks. So, unless the artist has simply made a mistake (a desperate conclusion), he is either simply in line, eagerly anticipating his turn with the eromenos, or actively seeks to displace the younger erastes. An unknown number of dancers appears on the band cup 23.

We have already noted traditional courting gifts, particularly cocks (26), and allusions to the hunt $(5,6,11)$; these elements are prominent in the remaining scenes that mostly lack dancers. Hunting dogs and javelins appear on the fragmentary tripod pyxis by the Amasis Painter (35), where the erastes uniquely fondles or masturbates his eromenos as an onlooker stands by with an aryballos for lubrication (cf. 26 above).

22 Sutton 2009, nos. 1-13, 30-33. 
Fig. 3: Cat. No. 21, Side A. Youth probably holding hare, dog; courting Type $\gamma$; courting, Type $\beta$ (?) Athens, National Archaeological Museum, inv. 19297. Photo: author. (c) Hellenic Ministry of Education and Religious Affairs, Culture and Sports/Archaeological Receipts Fund.

The Botkin Class neck amphora (24) sets the scene in a hunt with dogs and lively hunters who beckon across the florals. The lovers appear on both sides of the wellknown amphora by the Painter of Berlin 1686 (16) amid a wealth of courting gifts and game (live deer, dead hare, dead fox, and three game cocks), couples in various stages of courting, and a lone bearded dancer. This artist presents the couple (17) framed by varied three-figure groups in which two adult erastai pursue youths with wreaths, a cock, and hunting dogs. A tripod pyxis (36) paratactically disposes two Type y pairs with young erastai beside a less advanced courting pair, framed between a dancing man and a hopeful erastes with a cock. On the amphora from Pharsala (21, fig. 3) a youth probably proffered a hare that at least attracts the attention of his hound. Most unusual is the hydria (34), where a youth with a live hare moves between a Type $y$ couple and pederastic anal lovers who are uniquely presented without denigration. Hounds are also reported (30) and with a dancer $(23,33)$. The Gela Painter twice sets the scene amid Doric columns, perhaps indicating a gymnasium or a public stoa. On one (31) the couple is centered between pederastic courting pairs, one successful, the other not. On the Canellopoulos lekythos (32) with an androgynous eromenos, a man with dog regards the couple from left, with an earlier stage of courting of equally dubious gender to right. 


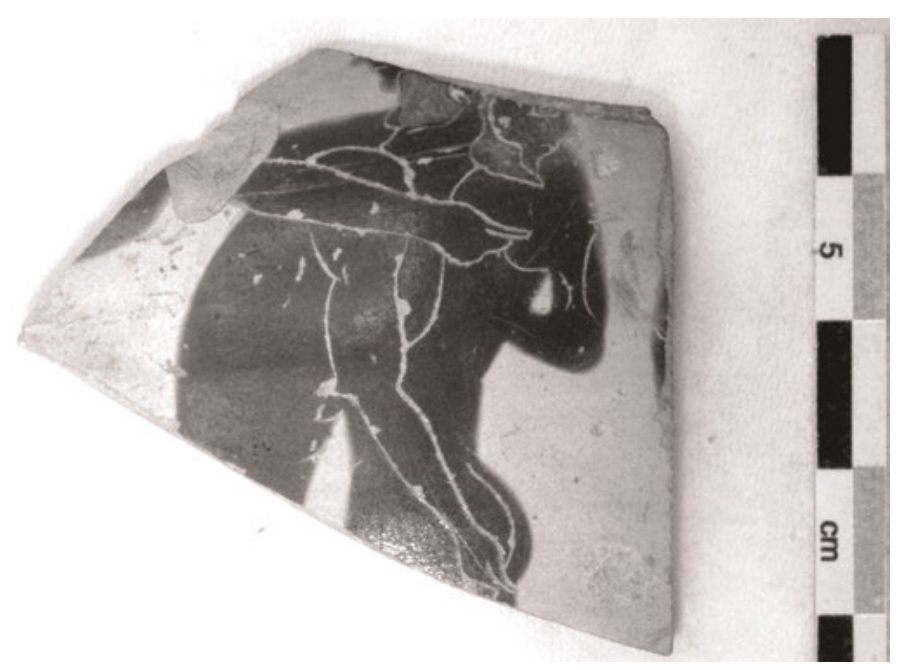

Fig. 4: Cat. No. 28 (fragment). Courting Type $\gamma$ framed by male figures; large chip on left drawn as female arm in Graef/Langlotz 1925, pl. 95.2242. Photo: author. (c) Hellenic Ministry of Education and Religious Affairs, Culture and Sports/Archaeological Receipts Fund.

Pederastic and heterosexual lovemaking appear together only twice. The witty Hermogenes, on a fragmentary cup (7), places the vertical, monochromatic pederastic group in the center, probably framed by crouching black and white heterosexual pairs, of which only the couple on right survives. ${ }^{23}$ On a later band cup (9), a pederastic couple stands off to the side of multiple crouching heterosexual couples making love in a vineyard. ${ }^{24}$ The white arm in the published drawing of the Acropolis fragment (28; fig. 4) is a chip that was misunderstood by the artist apparently working from a photograph.

In all these scenes, the standing young eromenos possesses dignity that contrasts with the few black-figure scenes of homosexual anal intercourse, usually ridiculed or shown as degradation (except 34), and heterosexual lovemaking, where the women are lascivious and often degraded. ${ }^{25}$ He displays little or no emotion, reflecting the ideal of male self-control that Shapiro has discovered in funeral scenes, in striking contrast to some enthusiastic female lovers, as on Hermogenes' band cup (7). ${ }^{26}$

The variety of vase shapes that carry a theme indicate the social context for which it was appropriate. Type $y$ appears on a wider range of black-figure shapes than heterosexual lovemaking (see Catalog) and is distributed more evenly among

23 Cf. the ridiculous Hermogenean juxtaposition: Sutton 2000, 188-189 figs. 7.3-4 and 2009, no. 39.

24 Cf. Topper 2012, Chapter 2, 27-28, 47-52.

25 Shapiro 2000, 16-19; Sutton 2000, 185-191, 195-199 and 2009; Lear/Cantarella 2008, 115-129.

26 Shapiro 1991. 
them. ${ }^{27}$ Significantly, both subjects appear predominately on symposion ware and often include Dionysian elements. Drinking vessels (cups and skyphoi) account for $42 \%$ of the vessels that portray Type $y$, and almost $75 \%$ of heterosexual lovemaking. Amphoras, mostly Type B, carry over a quarter of $y$ scenes but a smaller proportion of the heterosexual lovemaking. Of shapes not connected exclusively to the symposion, most common is the lekythos (22\%), the common jar for oil, a sexual lubricant, as noted. ${ }^{28}$ Lekythoi carry Dionysian subjects, and such elements occur here $(26,29)$. The rare tripod pyxis represents $6 \%$ of the total and possibly had a related use.

Exactly half the catalogued vases have recorded provenience, indicating the theme's wide appeal in Greek and barbarian lands (Table 1).

Table 1: Catalog Items With Known Provenience $\mathrm{N}=18$

Greece N $=6$ (33\%)

Athens, Acropolis and N. Slope: cups 3, 4; lekythos 28

Eleusis, Demeter Sanctuary: lekythos 33

Aegina, Sanctuary of Aphaia: tripod pyxis 35

Pharsala (grave): amphora 21

Etruria and Central Italy $\mathrm{N}=8(44 \%)$

Chiusi: cup 10

Falerii Veteres (tomb): lekythos 30

Saturnia: cup 15

Vulci: cup 9; amphora 16

Etruria: cups 2, 6

Villa Giulia Museum: lekythos 26

Sicily $\mathrm{N}=1(6 \%)$

Megara Hyblaia: amphora 20

Black Sea $\mathrm{N}=2(11 \%)$

Olbia: cup 8; lekythos 29 (grave)

Egypt $\mathrm{N}=1(6 \%)$

Naukratis: cup 13

A plurality (44\%) comes from Etruria and Central Italy (most or all surely from tombs), with a third from Greece, mostly from Athens and Attica (slightly higher than the heterosexual scenes). Two of the latter were found in religious sanctuaries, but the fragments from the Athenian Acropolis probably originated in fill brought from the

27 Sutton 2009, 89, Table 1.

28 Kilmer 1993, 81-82, 88-89. 
lower city; ${ }^{29}$ only the Pharsala amphora originated in a burial (21). The remainder come from Greek colonies on the Black Sea, Sicily, and Egypt; no. 29 from Olbia was found in a woman's grave with a bronze mirror and gold jewelry. Scenes of heterosexual lovemaking are more widely distributed, although their number is greater and a higher proportion is of known provenience $(67 \%){ }^{30}$

Other subjects pictured on the same vessel establish a wider iconographic context for viewing the theme. Reflecting the prominence of symposion ware, a slight plurality of vessels carries related sexual and/or festive themes. Courting is most common, generally Type $\alpha$ (21 [fig. 5], 24, 26, 31, the ambiguous 32); on at least three Type $y$ lovers are repeated $(12,14,16)$. On Hermogenes' band cup (7), the heterosexual lovers reported on Side B may indicate repetition of the presumed ABA scheme of side A. The dancers on the reverse of the amphora from Pharsala (21; fig. 5) accord with those on side A. Lovemaking is a subject of symposion ware ${ }^{31}$ and Dionysos is the favored divinity, present in every field of the Copenhagen eye cup (11), if we include the vines behind the lovers (as also 32); his vineyard is the setting for lovemaking and symposion on the Moscow (?)/Berlin band cup (9), and we have noted his entourage on two lekythoi $(26,29)$.

Pederastic lovemaking is ennobled by appearing with images of other gods and heroes: Athena is shown battling the Giant Enkelados (1), mounting a chariot, with Apollo and probably Artemis or Leto, and Hermes to lead the way (20), and possibly at her birth, as Shapiro suggests (17). The gods of the Spitzer amphora (25) are treated below. Nike appears on both exterior sides of a cup (2). The Dioskouroi (35) straddle the boundary between man and god, while two other heroes appear twice: Herakles, shown battling the lion (24) and Kyknos (35), a version in which Zeus intervenes; ${ }^{32}$ and Achilles, dueling Memnon (18) and gaming with Ajax (19). Scenes of noble mortal manly pursuits are rare: battles (1) and athletes (23) each appear once; only a pair of deer framing a siren on a shoulder refers to hunting (27); the siren lacks obvious relevance, although sirens also appear with heterosexual lovers. ${ }^{33}$ The subject of a lekythos shoulder involving a horse is uncertain (29). Larger programs can be discerned on vessels illustrating multiple themes: divine and mortal battles (1) and deified heroes, Dioskouroi, and Herakles (35) seem to ennoble the pederastic theme, while the tripod pyxis evidently celebrates erotic diversity (36).

The Type $y$ courting on the Spitzer amphora is thus unexceptional, yet the particular choice of deities on side $\mathrm{A}$ is remarkable for imparting new artistic pedagogic associations. I hinted that the dancers on side B respond to the music of Apollo on the

29 Stewart 2008a.

30 Sutton 2009, 89, Table 2.

31 Sutton 2009, 82-84.

32 Cf. Shapiro 1984.

33 Sutton 2009, 79, 81 fig. 5, 86 nos. 22, 23. 


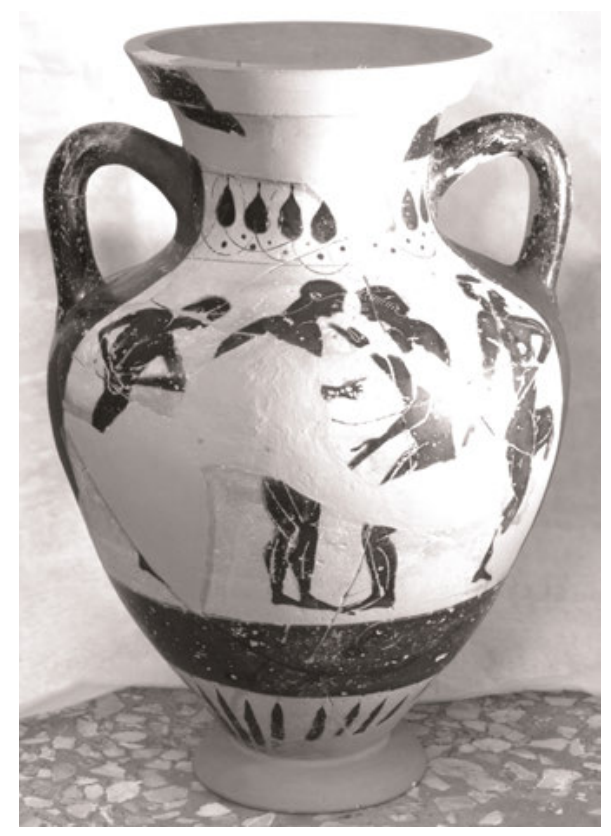

Fig. 5: No. 21, Side B. Courting Type $\alpha$ framed by dancing youths. As fig. 3 .

obverse. Yet the kithara did not normally accompany the dance but served as the instrument for formal concert performance and poetic recitation. ${ }^{34}$ Here it introduces an artistic aspect of gentlemanly Bildung to the previously recognized pederastic themes of hunt (an apt metaphor of courting), cockfighting, and athletics. It is difficult to imagine a more explicit and elevated allusion to the pedagogic aspect of pederasty than this pairing with Apollo the ephebe, "the most Greek of the gods," "the epitome of that turning point in the flower of youth," who, together with his sister Artemis, presided over the transition of youths and maidens to adulthood..$^{35}$ If the other gods require explanation, Hermes presides over transitions and often leads the way, while Poseidon seems generally appropriate as an adult male with local Athenian prominence, and perhaps he had seasonal relevance or personal connection to painter or client.

34 Smith 2010, 99; Bundrick 2005, 14-29.

35 Burkert 1985, 143-152, quoting 143, 145. 


\section{Catalog: Attic Black-figure Pederastic Courting Type $\gamma$}

See full references in DeVries' catalog (D numbers; Lear/Cantarella 2008, 194-233), BAPD (in parentheses), and Beazley 1989b ( $y$ numbers).

$\mathrm{P}=$ Painter; $\mathrm{I}$ = interior; $\mathrm{A}, \mathrm{B}=$ exterior sides; frag = fragment; $\mathrm{N}=$ total number.

Total Cups (kylikes): $\mathrm{N}=15(42 \%)$

Lip cup, $\mathrm{N}=6$

1. D 2.3 (3503693). Copenhagen 13966. Epitimos P. I; A, B (lip) Gigantomachy, Athena vs. Enkelados; (heads); by handles: duels (Greek vs. barbarian): A: on horse, B on foot. Heesen 2011, 156, 287-288 no. 236 pls. 67, 68; dated ca. 550 BCE.

2. D 2.21 (302570; y 3). Moscow (?) (Berlin F 1773), ${ }^{36}$ from Etruria. Near P of Boston C. A. A; I, nonsense inscriptions; B: Nike.

3. D 2.92 ( $y$ 10). Athens, National Archaeological Museum, Agora A-P 733, frag., from Athens, Acropolis N. Slope. I. Pease 1935, 262, 267-268 no. 103 fig. 25.

4. D 2.93 ( $y$ 11). Athens, Acr. 1761, from Athens, Acropolis, frag. I, inscription $\Theta . M$. (sic).

5. D 2.112 (3878). Bochum S1024. Epitimos P. I, 2 names, including QONON; A, B: nonsense inscriptions. Heesen 2011, 156, 288 no. 230 pl. 20; dated ca. 545540 BCE.

6. D 2.91 (7479; y 9). Paris CP55, from Etruria. I.

Band cup, $\mathrm{N}=4$

7. D 2.13 (6408, 44981). Helgoland, Kropatschek, frag. Hermogenes P, signed by potter Hermogenes. A: $y$, heterosexual lovers on right, probably also originally on left; B: heterosexual couple making love (not seen; possibly duplicate of A). Heesen 2011, 102-111, 277 no. 149 pl. 46b; dated ca. 545-540 BCE.

8. Olbia, frag. from Olbia. A, framed by dancing nude males, dancing women in skirts. Kryžickij 1989, 62 fig. 22.9.

9. D 2.95 (11037; y 13). Moscow (?) (Berlin F 1798), ${ }^{37}$ from Vulci. B, in vineyard; A, symposion under vines.

10. D 2.87 ( $y$ 2). Florence, ex Vagnoville, patch band cup frag., from Chiusi. Iozzo 2006, pl. X.6.

Type $\mathrm{A}, \mathrm{N}=3$

11. D 3.24 (302651). Kurashiki, Ninagawa 27. Krokotos Group; cf. Group of 48.42 I; zone: Dionysos \& thiasos; A, B with eyes, Dionysos \& Ariadne, Dionysoi; dolphins under handle.

36 Zhuravlev/Lomtadze 2007.

37 Seen. 36. 
12. BAPD 350784. Toulouse, 26.088. Group of the Courting Cups, FP Class. A, B.

13. D 3.43 ( $y$ 14). Oxford G 1112, frag. from Naukratis. A, upper part of couple (not seen).

Other or uncertain, $\mathrm{N}=2$

14. D 2.109. Skyphos of Hermogenean Type. Basel Market. Strobos P. A, B. Heesen 2011, nn. 638, 657, 723.

15. D 2.94 (y 12). Band cup or band skyphos. Once Rome, Hartwig, from Saturnia. A, between eyes, palmettes.

Total Amphoras: $\mathrm{N}=10(28 \%)$

Type B: $\mathrm{N}=8$

16. D 2.59 (320395). London 1865.11-18-39, from Vulci. P of Berlin 1686. A, B.

17. BAPD 7277. San Antonio 86.134.44. P of Berlin 1686. B; A, gods (birth of Athena?). Shapiro 2000, fig. 2.

18. D 2.89 (2889; y 7) Cambridge, loan from Trinity College T2. B; A: Achilles vs. Memnon.

19. D 2.90 (10478; y8). Sèvres 6405. B; A, Ajax and Achilles playing.

20. D 3.47 (14208). Syracuse 9762, from Megara Hyblaia. B; A, Athena mounts chariot, with gods.

21. D 3.45. Athens 19297, from Pharsala (grave). A; B dancers frame Type $\alpha$ courting. (Here figs. 3, 5).

22. BAPD 9040. London Market. Euphiletos P. A; B, dancers.

23. D 3.32 (360885) Ex Milan, Vanzetti. Very close to Edinburgh P. A; athletes. Para 219 (not seen).

Neck Amphora: $\mathrm{N}=2$

24. D 2.16 (14). Market. Botkin Class. B; A: courting, Type $\alpha$; shoulder A, B: Herakles vs. lion.

25. D 3.49. Bryn Mawr 2011.17.2. B; A: gods in musical procession. (Here color figs. 38-39; figs. 1, 2).

Lekythos: $\mathrm{N}=8(22 \%)$. Scene on body.

26. D 2.19 (301130; y 4). Rome, Villa Giulia 50653. Taleides P. Shoulder: Type $\alpha$.

27. D 2.20 (350510). Princeton 86.53. Taleides P. Shoulder: siren between deer.

28. 2.88 ( $y$ 6). Athens, Acr. 2242, from Athens, Acropolis. Taleides Painter or close. (Here fig. 4).

29. D 2.73 (y 5). St. Petersburg 0.1912.272, from Olbia (grave). Cf. P of the Carlsruhe Skyphos. Shoulder: youths, figure in chiton, horse, all running. Trofimova 2007, 100-102 (color).

30. D 3.42 (14208; y 5bis). Rome, Villa Giulia 1392, from Falerii Veteres (Civita Castellana; tomb). Near Cock Class, Haspels 1936, 67. 
31. D 4.45 (41361) New York Market. Gela P. With other courting. Royal Athena Galleries 2001, 70 no. 198.

32. D 4.2. Athens, Canellopoulos Museum $\Delta$ 40. Gela P. Between columns, y group (heterosexual?, as Zarkadas believes) between man with hound, heterosexual (?) courting.

33. D 2.103. Eleusis, from sanctuary of Demeter \& Kore. Man/boy, hound, dancer (not seen).

Hydria (kalpis): $\mathrm{N}=1(3 \%)$

34. 2.100 (5890) New York, Private. y group, youth with hare, pederastic anal intercourse. Shapiro 2000, fig. 7; Sutton 2000, fig. 7.2; Lear/Cantarella 2008, fig. 3.8.

Tripod pyxis: $\mathrm{N}=2(6 \%)$.

35. 2.12 (14701). Aegina, from Aegina, Aphaia sanctuary, frag. Amasis P. C; A: Dioskouroi; B: Herakles vs. Kyknos.

36. 2.106. Oxford, Miss. A; B: heterosexual courting (?); C: 2 women share mantle.

\section{Addenda}

Courtesy Michael Padgett

11bis. Tampa, Zewadski, Cup, Type A frag. Group of the Courting Cups (Padgett?). A: upper half of $y$ pair between male dancers.

25bis. Neck amphora, Lausanne, Musée Olympique BA no. 9024527. A: Central y pair between $\alpha$ pairs.

27bis. Lekythos, London Market. Central y pair between nude dancing men between dancing women in nebris. Shoulder: equestrian youth between standing males. Christie's, London, September 23, 1998 no. 177. 


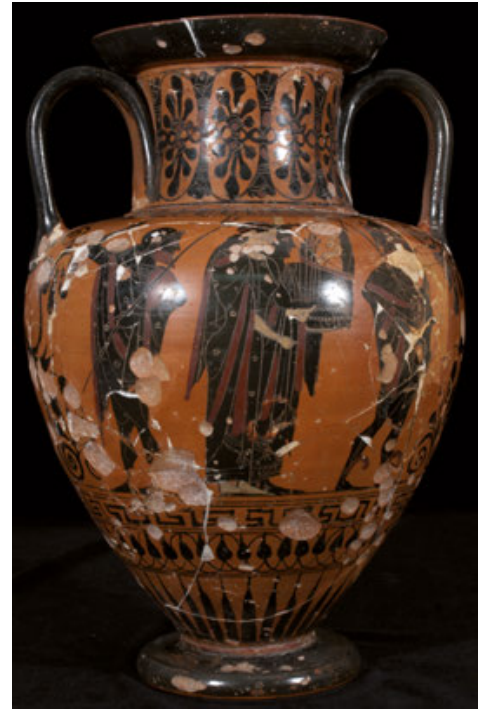

Fig. 38: Cat. No. 25, Side A, Apollo and Artemis with Poseidon and Hermes. Bryn Mawr College Art and Artifact Collections, 2011.17.2. Gift of Doreen Canaday Spitzer, Class of 1936. Photo Bryn Mawr College Art \& Artifact Collections.

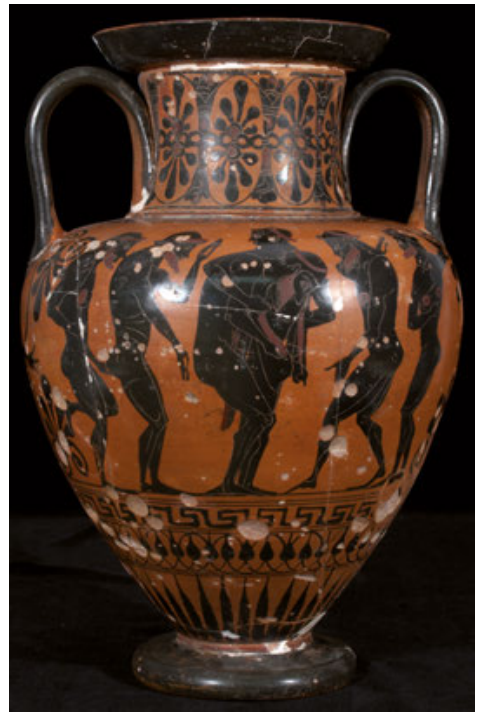

Fig. 39: Cat. No. 25. Side B. Pederastic courting Type $\gamma$. As color fig. 38. 


\section{Bibliography}

Adornato, Gianfranco (2003), “I guerrieri di Agrigento,” Prospettiva 110-111, 2-17.

Adornato, Gianfranco (2013), "Rivalry, Competition, and Promotion: Cities and Citizens of Sicily in the Sanctuaries of Greece," in Claire L. Lyons/Michael Bennett/Clemente Marconi (eds.), Sicily: Art and Invention between Greece and Rome, Malibu, 82-97.

Adornato, Gianfranco (ed.) (2010), Scolpire il marmo. Importazioni, artisti itineranti, scuole artistiche nel Mediterraneo antico, Atti del convegno di studio tenuto a Pisa, Scuola Normale Superiore, 9-11 novembre 2009, Milan.

Aellen, Christian (1994), A la recherche de l'ordre cosmique: Forme et fonction des personnifications dans la céramique italiote, Akanthus crescens 2, Kilchberg/Zurich.

Aellen, Christian/Cambitoglou, Alexander/Chamay, Jacques (1986), Le peintre de Darius et son milieu, Geneva.

Agulhon, Maurice (1981), Marianne into Battle: Republican Imagery and Symbolism in France, 1789-1880, Cambridge.

Ahlberg-Cornell, Gudrun (1984), Herakles and the Sea-Monster in Attic Black-Figure Vase-Painting. Skrifter Utgivna av Svenska Institutet i Athen, $4^{\circ}$, XXXIII, Stockholm.

Ahlberg-Cornell, Gudrun (1992), Myth and Epos in Early Greek Art: Representation and Interpretation, Jonsered.

Akurgal, Ekrem (1982), Alt-Smyrna I. Wohnschichten und Athena-Tempel, Ankara.

Al-Khalil, Samir (1991), The Monument. Art, Vulgarity, and Responsibility in Iraq, Berkeley.

Alaimo, Rosario/Carapezza, Marcello (1988), “Il marmo della statua di Mozia: Caratteri geochimici e possibili aree di provenienza," in Nicola Bonacasa/Antonino Buttitta (eds.), La statua marmorea di Mozia e la scultura di stile severo in Sicilia, Atti della giornata di studio, Marsala, 1 giugno 1986, Rome, 29-37.

Albersmeier, Sabine (2004), “Das 'Issisgewand' der Ptolemäerinnen. Herkunft, Form und Funktion,” in Peter C. Bol/Gabriele Kaminski/Caterina Maderna (eds.), Fremdheit-Eigenheit. Ägypten, Grie-

chenland und Rom, Austausch und Verständnis, Städel Jahrbuch N.F. Vol. 19, Stuttgart, 421-432.

Albersmeier, Sabine (ed.) (2008), The Art of Ancient Greece. The Walters Art Museum, Baltimore.

Albertson, Fred C. (2002), “Zenodorus's 'Colossus of Nero,"” MAAR 46, 95-118.

Alexander, Christine (1932), "Some Plaster Reliefs from Alexandria," BMM 27, 197-198.

Alexandridou, Alexandra (2011a), The Early Black-figured Pottery of Attika in Context (c. 630-570 BCE), Leiden.

Alexandridou, Alexandra (2011b), "Hermes in Attic Early Black-figured Vase Painting. Reflections of Contemporary Attica," BABesch 86, 15-26.

Alexiou, Margaret (2002), The Ritual Lament in Greek Tradition, $2^{\text {nd }}$ edn., revised by Dimitrios Yatromanolakis/Panagiotis Roilos, Lanham, MD.

Alfieri, Nereo (1959), “Dalle necropoli di Spina. Grande kylix del Pittore di Penthesilea con ciclo teseico," RIA 8, 59-110.

Aloni, Antonio (2003), "Teseo un eroe dalle molte identità," in Marcella Guglielmo/Edoardo Bona (eds.), Forme di comunicazione nel mondo antico e metamorfosi del mito: Dal teatro al romanzo, Alexandria, 1-22.

Amandry, Pierre (1971), "Collection Paul Canellopoulos," BCH 95, 585-626.

Amandry, Pierre (1980), "Sur les concours argiens," in Études argiennes, BCH Supplement 6, Paris, 211-253.

Amandry, Pierre (2002), “Hydries argiennes," in Andrew J. Clark/Jasper Gaunt (eds.), Essays in Honor of Dietrich von Bothmer, Amsterdam, 29-32.

Amandry, Pierre/Amyx, Darrell A. (1982), "Hérakles et l'hydre de Lerne dans la céramique corinthienne," $A K 25,102-116$. 
Ampolo, Carmine (2012), “Compresenza di ethne e culture diverse nella Sicilia occidentale. Per una nuova prospettiva storica," in Francesca Berlinzani (ed.), Convivenze etniche, scontri e contatti di culture in Sicilia e Magna Grecia, Aristonothos 7, 15-57.

Ampolo, Carmine/Manfredini, Mario (eds.) (1988), Plutarco. Le vite di Teseo e Romolo, Milano.

Amyx, Darrell A. (1988), Corinthian Vase Painting of the Archaic Period, 3 vols., Berkeley.

Andersen, Øivind/Dag, Haug T. T. (eds.) (2012), Relative Chronology in Early Greek Epic Poetry, Cambridge.

Anderson, Michael J. (1997), The Fall of Troy in Early Greek Poetry and Art, Oxford.

Anderson, Michael J. (2009), "Heroes as Moral Agents and Moral Exemplars," in Sabine Albersmeier (ed.), Heroes: Mortals and Myths in Ancient Greece, Exhibition Catalogue, Walters Art Museum Baltimore, 144-173.

Andreae, Bernard (1995), Bildkatalog der Skulpturen des vatikanischen Museums I. Museo Chiaramonti 3, Berlin.

Andreou, Andreas (1989), Griechische Wanddekorationen, Ph.D. Diss., Johannes Gutenberg Universität zu Mainz.

Andrianou, Dimitra (2009), The Furniture and Furnishings of Ancient Greek Houses and Tombs, Cambridge.

Andronikos, Manolis (1994), Vergina II. The "Tomb of Persephone," Athens.

Arnott, Geoffrey W. (2007), Birds in the Ancient World from A to Z, London/New York.

Arrigoni, Giampiera (1977), “Atalante e il cinghiale bianco,” ScrPhil 1, 9-47.

Arrigoni, Giampiera (2009), “Le Amazzoni ad Atene: La guerra, la morte, l'onore, i culti,” in Federica Giacobello (ed.), Le Ore della Donna: Storie e immagini della collezione di ceramiche attiche e magnogreche di Intesa Sanpaolo, Vicenza, 47-61.

Arrington, Nathan T. (2010), “Topographic Semantics: The Location of the Athenian Public Cemetery and its Significance for the Nascent Athenian Democracy," Hesperia 79, 499-539.

Arrington, Nathan T. (2011), “Inscribing Defeat: The Commemorative Dynamics of the Athenian Casualty Lists," ClAnt 30, 180-212.

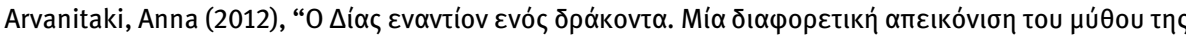

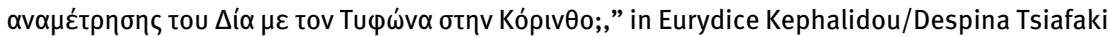

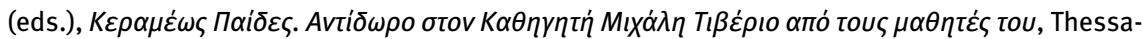
loniki, 171-178.

Ashmole, Bernard/Yalouris, Nikolaos (1967), Olympia: The Sculptures of the Temple of Zeus, London.

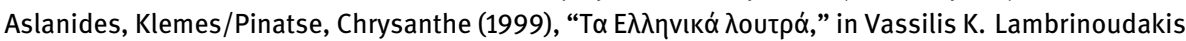

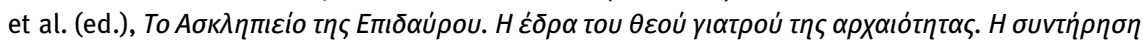
$\tau \omega v \mu v \eta \mu \varepsilon i \omega v \tau o u$, Athens, 51-52.

Aston, Emma (2011), Mixanthrôpoi: Animal-human Hybrid Deities in Greek Religion, Liège.

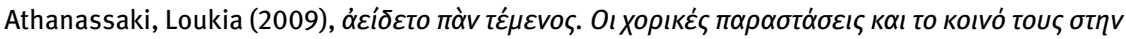

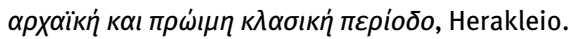

Athanassakis, Apostolos N. (trans.) (2004), The Homeric Hymns, $2^{\text {nd }}$ edn., Baltimore.

Auffarth, Christoph (1991), Der drohende Untergang: "Schöpfung" in Mythos und Ritual im Alten Orient und in Griechenland am Beispiel der Odyssee und des Ezechielbuches, Religionsgeschichtliche Versuche und Vorarbeiten, Berlin.

Ault, Bradley A. (2000), “Living in the Classical Polis. The Greek House as a Microcosm,” CW 93 , 483-496.

Ault, Bradley A./Nevett, Lisa C. (eds.) (2005), Ancient Greek Houses and Households: Chronological, Regional, and Social Diversity, Philadelphia.

Aurigemma, Salvatore (1960), La necropoli di Spina in Valle Trebba, I, Scavi di Spina I, Rome.

Avramidou, Amalia (2011), The Codrus Painter: Iconography and Reception of Athenian Vases in the Age of Pericles, Madison. 
Aydınoğlu, Ümit/Şenol, Ahmet Kaan (eds.) (2010), Antik Çağda Anadolu'da Zeytinyağı ve Şarap Üretimi, Sempozyum Bildirileri, 06-08 Kasım 2008, Mersin, Türkiye (Olive Oil and Wine Production in Anatolia During Antiquity, Symposium Proceedings, 6-8 November 2008, Mersin, Turkey), Istanbul.

Bacigalupi, Don et al. (2009), The Toledo Museum of Art Masterworks, Toledo.

Badinou, Panayota (2003), La laine et le parfum. Epinetra et alabastres: Forme, iconographie et fonction. Recherche de céramique attique feminine, Louvain.

Bahrani, Zainab (1995), “Assault and Abduction: The Fate of the Royal Image in the Ancient Near East," Art History 18, 363-382.

Bakalakis, Georgios (1971), “Die Lutrophoros Athen (ex Schliemann)-Berlin 3209,” AK14, 74-83.

Bakır, Güven (1981), Sophilos. Ein Beitrag zu seinem Stil, Mainz.

Balme, David M. (1991), Aristotle: History of Animals, Books 7-10, Cambridge, MA.

Barbanera, Marcello (1992), "Ancora sulla stele funeraria di Antipatros di Ascalona. Una messa a punto," NAC 21, 87-103.

Barbanera, Marcello (2010), “Nudity," in Michael Gagarin/Elaine Fantham (eds.), Oxford Encyclopedia of Ancient Greece and Rome, Vol. 5, Oxford, 77-79.

Barbanera, Marcello (forthcoming), "The Lame God: Ambiguities of Hephaistos in the Greek Mythical Realm,” in H. A. (H. Alan) Shapiro/Frank Wascheck (eds.), Fluide Körper-Bodies in Transition, Proceedings of the Conference held at the Morphomata Kolleg, Cologne, 26-27 May 2011.

Barber, Elizabeth J. W. (1991), Prehistoric Textiles: The Development of Cloth in the Neolithic and Bronze Ages with Special Reference to the Aegean, Princeton.

Barber, Elizabeth J. W. (1992), “The Peplos of Athena," in Jenifer Neils (ed.), Goddess and Polis. The Panathenaic Festival in Ancient Athens, Princeton, 103-118.

Bardel, Ruth (2000), “EIDÔLA in Epic, Tragedy and Vase-Painting,” in N. Keith Rutter/Brian A. Sparkes (eds.), Word and Image in Ancient Greece, Edinburgh, 140-160.

Barr-Sharrar, Beryl (2008), The Derveni Krater: Masterpiece of Classical Greek Metalwork, Ancient Art and Architecture in Context I, Princeton.

Barr-Sharrar, Beryl/Newman, Richard (2009), "A Classical Greek Bronze Situla with Figurative Relief in the Museum of Fine Arts, Boston," Materials and Manufacturing Processes 24.9, 972-974.

Barringer, Judith M. (2001), The Hunt in Ancient Greece, Baltimore.

Barringer, Judith M. (2003), "Panathenaic Games and Panathenaic Amphorae under Macedonian Rule," in Olga Palagia/Stephen V. Tracy (eds.), The Macedonians in Athens 322-229 B.C., Oxford, 243-256.

Barringer, Judith M. (2005), “The Temple of Zeus at Olympia, Heroes, and Athletes,” Hesperia 74, 211-241.

Barringer, Judith M. (2009), "A New Approach to the Hephaisteion: Heroic Models in the Athenian Agora," in Peter Schultz/Ralf von den Hoff (eds.), Structure, Image, Ornament: Architectural Sculpture in the Greek World, Proceedings of an International Conference Held at the American School of Classical Studies, 27-28 November 2004, Oxford, 105-120.

Batino, Sabrina (2002), Lo Skyphos attico dall'iconografia alla funzione, Naples.

Baumeister, Peter (2007), Der Fries des Hekateions von Lagina: Neue Untersuchungen zu Monument und Kontext, Istanbul.

Beavis, Ian C. (1988), Insects and Other Invertebrates in Classical Antiquity, Exeter.

Beazley, J. D. (John Davidson) (1918), Attic Red-Figured Vases in American Museums, Cambridge.

Beazley, J. D. (John Davidson) (1920), The Lewes House Collection of Ancient Gems, Oxford.

Beazley, J. D. (John Davidson) (1925), Attische Vasenmaler des rotfigurigen Stils, Tübingen.

Beazley, J. D. (John Davidson) (1927), “Icarus,” JHS 47, 222-233. 
Beazley, J. D. (John Davidson) (1928), Greek Vases in Poland, Oxford.

Beazley, J. D. (John Davidson) (1929), “Notes on the Vases in Castle Ashby," PBSR 11, 1-29.

Beazley, J. D. (John Davidson) (1933), Campana Fragments in Florence, Oxford.

Beazley, J. D. (John Davidson) (1934), “The Troilos Cup,” MMS 5.1, 93-115.

Beazley, J. D. (John Davidson) (1940-45), “Miniature Panathenaics," ABSA 41, 10-21.

Beazley, J. D. (John Davidson) (1944), “Groups of Early Attic Black-Figure," Hesperia 13, 38-57.

Beazley, J. D. (John Davidson) (1947), Etruscan Vase-Painting, Oxford.

Beazley, J. D. (John Davidson) (1949), "Some Panaitian Fragments," in Commemorative Studies in honor of Theodore Leslie Shear, Hesperia Supplement 8, Princeton, 3-5.

Beazley, J. D. (John Davidson) (1951), “A Hoplitodromos Cup,” ABSA 46, 7-15.

Beazley, J. D. (John Davidson) (1957), "Review of Frank Brommer, CVA Schloss Fasanerie I,” AJA 61, 110-111.

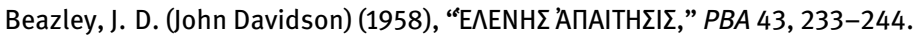

Beazley, J. D. (John Davidson) (1974), The Berlin Painter, Mainz.

Beazley, J. D. (John Davidson) (1986), The Development of Attic Black-Figure, rev. edn., Berkeley/Los Angeles.

Beazley, J. D. (John Davidson) (1989a), Greek Vases. Lectures, ed. by Donna C. Kurtz, Oxford.

Beazley, J. D. (John Davidson) (1989b), Some Attic Vases in the Cyprus Museum, ed. by Donna C. Kurtz, rev. edn., Oxford.

Beck, Herbert/Bol, Peter C./Bückling, Maraike (eds.) (1990), Polyklet. Der Bildhauer der griechischen Klassik, Ausstellung im Liebieghaus Museum alter Plastik, Frankfurt, Mainz.

Becker, Regina-Maria (1977), Formen attischer Peliken von der Pionier-Gruppe bis zum Beginn der Frühklassik, Böblingen.

Beckman, Gary M./Bryce, Trevor R./Cline, Eric H. (2011), The Ahhiyawa Texts, Atlanta.

Behrendt, Kurt (2007), The Art of Gandhara in The Metropolitan Museum of Art, New Haven.

Bell, Malcolm (1995), “The Motya Charioteer and Pindar's Isthmian 2,” MAAR 40, 1-42.

Bell, Sinclair (2003a), “Codex Coburgensis Nr. 21. Ein Verschollener Zirkussarkophag in Privatbesitz," Kölner Jahrbuch 36, 297-307.

Bell, Sinclair (2003b), “Cumont's Shadow: Spectacle and Symbolism in Roman Funerary Art," Cosmos 19, 79-115.

Bell, Sinclair (2005), "Responding to the Antique. A Rediscovered Roman Circus Sarcophagus and its Renaissance Afterlife," Pegasus 7, 49-80.

Bell, Sinclair (2007-2008), "Roman Circus Sarcophagi: New, Lost and Rediscovered Finds," Boreas 30/31, 127-140.

Belting-Ihm, Christa (1961), “Ein römischer Circus-Sarkophag,” JRGZ 8, 195-208.

Ben Abed, Aicha (2006), Tunisian Mosaics: Treasures from Roman Africa, Los Angeles.

Benardete, Seth (1969), Herodotean Inquiries, The Hague.

Beningson, Robin/Coplin, Joseph (2005), Ancient Treasures III, New York.

Benson, Carol (1995), “Circe,” in Ellen D. Reeder (ed.) (1995), Pandora: Women in Classical Greece, Exhibition Catalogue Walters Art Gallery, Baltimore, 403-404.

Benton, Sylvia (1972), “Echelos' Hippodrome,” ABSA 67, 13-19.

Bentz, Martin (1998), Panathenäische Preisamphoren. Eine athenische Vasengattung und ihre Funktion vom 6.-4. Jahrhundert v. Chr., AK Beiheft 18, Basel.

Bentz, Martin (2001a), “Appendix 1: Schwarzfigurige Pseudo-Preisamphoren (ca. 550-475 v. Chr.)," in Martin Bentz/Norbert Eschbach (eds.), Panathenaïka. Symposion zu den Panathenäischen Preisamphoren, Rauischholzhausen 25.11.-29.11.1998, Mainz, 177-195.

Bentz, Martin (2001b), “Appendix 2: Schwarzfigurige Miniature-Preisamphoren,” in Martin Bentz/ Norbert Eschbach (eds.), Panathenaïka. Symposion zu den Panathenäischen Preisamphoren, Rauischholzhausen 25.11.-29.11.1998, Mainz, 196-198. 
Bentz, Martin (2001c), "Schwarzfigurige Amphoren panathenäischer Form. Typologie, Funktion und Verbreitung," in Martin Bentz/Norbert Eschbach (eds.), Panathenaïka. Symposion zu den Panathenäischen Preisamphoren, Rauischholzhausen 25.11.-29.11.1998, Mainz, 111-117.

Bentz, Martin (2007), “Torch Race and Vase-painting,” in Olga Palagia/Alkestis Choremi-Spetsieri (eds.), The Panathenaic Games, Proceedings of an International Conference held at the University of Athens, May 11-12, 2004, Oxford, 73-80.

Bentz, Martin/Kästner, Ursula (eds.) (2007), Konservieren oder Restaurieren: Die Restaurierung griechsicher Vasen von der Antike bis Heute, CVA Beiheft 3, Munich.

Bérard, Claude (1977), “Architecture et politique: Réception d’une ambassade en Grèce archaïque," EL 10, 1-25.

Bérard, Claude (1980), "Review of Christiane Sourvinou-Inwood, Theseus as Son and Stepson. A Tentative Illustration of Greek Mythological Mentality, London 1979," Gnomon 52, 616-620.

Bérard, Claude (2000), "The Image of the Other and the Foreign Hero," in Beth Cohen (ed.), Not the Classical Ideal: Athens and the Construction of the Other in Greek Art, Leiden, 390-412.

Bérard, Claude/Bron Christiane (1990), “Le liknon, le ‘masque’ et le poteau: Images du rituel dionysiaque,” Mélanges Pierre Lévêque 4, 29-44.

Bergemann, Johannes (1996), “Die sogenannte Lutrophoros: Grabmal für unverheiratete Tote?,” $\operatorname{MDAI}(A)$ 111, 149-190.

Bergmann, Bettina (2012), "The Flight of Icarus in the House of the Priest Amandus in Pompeii," in Mary D. Edwards/Elizabeth Bailey (eds.), Gravity in Art: Essays on Weight and Weightlessness in Painting, Sculpture and Photography, Jefferson, NC, 13-21.

Bergmann, Marianne (1994), Der Koloss Neros, die Domus Aurea und der Mentalitätswandel im Rom der frühen Kaiserzeit, Mainz.

Bergmann, Marianne (1998), Die Strahlen der Herrscher: Theomorphes Herrscherbild und politische Symbolik im Hellenismus und in der römischen Kaiserzeit, Mainz.

Beschi, Luigi (1982), “I donari tarantini a elfi: Alcune osservazioni,” in Luigi Beschi et al. (eds.), Aparchai. Nuove ricerche e studi sulla Magna Grecia e la Sicilia antica in onore di Paolo Enrico Arias, Vol. 1, Pisa, 227-238.

Bettini, Maurizio/Franco, Cristiana (2010), Il mito di Circe: Immagini e racconti dalla Grecia a oggi, Turin.

Binder, Judith (1984), "The West Pediment of the Parthenon: Poseidon," in Alan L. Boegehold et al. (eds.), Studies Presented to Sterling Dow on his Eightieth Birthday, Durham, NC, 15-22.

Biraschi, Anna Maria (2003), “'"'altro' Teseo. Mito, storia, politica e storiografia ad Atene nel V scolo a.C.," A\&R 48, 49-62.

Birchler Émery, Patrizia (1999), “Old-Age Iconography in Archaic Greek Art,” MedArch 12, 17-28.

Bisi, Anna Maria (1988), "La statua di Mozia nel quadro della scultura fenicio-punica di ispirazione greca," in Nicola Bonacasa/Antonino Buttitta (eds.), La statua marmorea di Mozia e la scultura di stile severo in Sicilia, Atti della giornata di studio, Marsala, 1 giugno 1986, Rome, 69-78.

Blegen, Carl W. (1937), Prosymna, the Helladic Settlement Preceding the Argive Heraeum, Cambridge.

Blinkenberg Hastrup, Helene (2003), The Castellani Fragments in the Villa Giulia. Athenian Black Figure Vol. 2, Aarhus.

Blok, Josine H. (2006), “Solon's Funerary Laws: Questions of Authenticity and Function," in Josine H. Blok/André P. M. H. Lardinois (eds.), Solon of Athens: New Historical and Philological Approaches, Leiden, 197-247.

Blome, Peter (1977), “Begram und Rom: Zu den Vorbildern des Aktaionsarkophage im Louvre,” AK 20, 43-53.

Blome, Peter (2001), “Der Mythos in der griechischen Kunst: Der Troianische Krieg findet statt,” in Troia: Traum und Wirklichkeit, Traveling Exhibition Catalogue, Archäologischen Landesmuseum Baden-Württemberg, Stuttgart, 118-153. 
Blundell, Sue (2004), “Scenes from a Marriage: Viewing the Imagery on a Lebes Gamikos," in Simon Keay/Stephanie Moser (eds.), Greek Art in View: Studies in Honour of Brian Sparkes, Oxford, 39-53.

Boardman, John (1971), “A Southern View of Situla Art,” in John Boardman/M. A. Brown/Thomas

G. E. Powell (eds.), The European Community in Later Prehistory: Studies in Honour of

C. F. C. Hawkes, London, 121-140.

Boardman, John (1974), Athenian Black Figure Vases. A Handbook, London/New York.

Boardman, John (1980), "The Castle Ashby Vases," in Christie, Manson and Woods, London, Sale Catalogue July 2, 11.

Boardman, John (1985), Greek Sculpture. The Classical Period. A Handbook, London/New York.

Boardman, John (1989), "Herakles at Sea," in Hans-Ulrich Cain/Hanns Gabelmann/Dieter Salzmann (eds.), Festschrift für Nikolaus Himmelmann. Beiträge zur Ikonographie und Hermeneutik, Beihefte der Bonner Jahrbücher 47, Mainz, 191-195.

Boardman, John (1996a), Greek Art, $4^{\text {th }}$ edn., London/New York.

Boardman, John (1996b), “Iconographic Signals in the Work of the Priam Painter," in Giovanni Rizza (ed.), I vasi attici ed altre ceramiche coeve in Sicilia, Vol. 1, Palermo, 19-30.

Boardman, John (1998a), Early Greek Vase Painting: $11^{\text {th }}-6^{\text {th }}$ centuries BC, London/New York.

Boardman, John (1998b), “The Ragusa Group," in Gabriella Capecchi et al. (eds.), In memoria di Enrico Paribeni, Rome, 59-65.

Boardman, John (2001), Greek Gems and Finger Rings. Early Bronze Age to Late Classical, $2^{\text {nd }}$ edn., London/New York.

Boardman, John (2002), The Archaeology of Nostalgia: How the Greeks Re-Created their Mythical Past, London/New York.

Boardman, John (2007), “Athenian Theseus and Some Ancient Greek Punishments and Executions,"

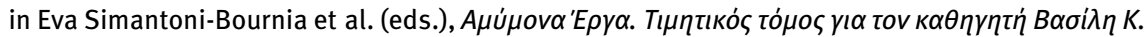

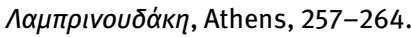

Boardman, John et al. (1976), Die griechische Kunst, $3^{\text {rd }}$ edn., Munich.

Bocci Pacini, Piera/Nocentini Sbolci, Simonetta (1983), Catalogo delle sculture romane, Museo nazionale archeologico di Arezzo, Rome.

Bocci Pacini, Piera et al. (1975), Roselle. Gli scavi e la mostra, Pisa.

Boedeker, Deborah (1988), "Protesilaos and the End of Herodotus' Histories," ClAnt 7, 30-48.

Boedeker, Deborah (2002), "Epic Heritage and Mythical Patterns in Herodotus," in Egbert J.

Bakker/Irene J. F. de Jong/Hans van Wees (eds.), Brill's Companion to Herodotus, Leiden, 97-116.

Böhr, Elke (1982), Der Schaukelmaler, Mainz.

Böhr, Elke (1992), “Vogelfang mit Leim und Kauz,” AA, 573-583.

Böhringer, E. (1929), Die Münzen von Syrakus, Berlin.

Bol, Peter C. (1990), “Herakles Kat. 60-65,” in Herbert Beck/Peter C. Bol/Maraike Bückling (eds.), Polyklet. Der Bildhauer der griechischen Klassik, Ausstellung im Liebieghaus Museum alter Plastik, Frankfurt, Mainz, 199-205.

Bonacasa, Nicola/Buttitta, Antonino (eds.) (1988), La statua marmorea di Mozia e la scultura di stile severo in Sicilia, Atti della giornata di studio, Marsala, 1 giugno 1986, Rome.

Borgers, Olaf (2004), The Theseus Painter: Style, Shapes and Iconography, Allard Pierson Series 16, Amsterdam.

Börker, Christoph (1983), Festbankett und griechische Architektur, Xenia 4, Konstanz.

Boschung, Dietrich (1987), Antike Grabaltäre aus den Nekropolen Roms, Acta Bernensia 10, Bern.

Boschung, Dietrich (1993), "Grabaltäre mit Girlanden und frühe Girlandensarkophage. Zur Genese der kaiserzeitlichen Sepulkralkunst," in Guntram Koch (ed.), Grabeskunst der römischen Kaiserzeit, Mainz, 37-42. 
Bosher, Kathryn (2012), “Hieron's Aeschylus,” in Kathryn Bosher (ed.), Theater Outside Athens: Drama in Greek Sicily and South Italy, Cambridge, 97-111.

Bothmer, Dietrich von (1957), Amazons in Greek Art, Oxford.

Bothmer, Dietrich von (1965), "Review of Erika Diehl, Die Hydria. Formgeschichte und Verwendung im Kult des Altertums, Mainz 1964," Gnomon 37, 599-608.

Bothmer, Dietrich von (1977), “Les vases de la collection Campana," RLouvre 27, 213-221.

Bothmer, Dietrich von (1979), “A Bronze Oinochoe in New York,” in Günter Kopcke/Mary B. Moore (eds.), Studies in Classical Art and Archaeology: A Tribute to Peter Heinrich von Blanckenhagen, Locust Valley, NY, 63-67.

Bothmer, Dietrich von (1984), “A Greek and Roman Treasury,” BMM 42, 1-72.

Bothmer, Dietrich von (1985), The Amasis Painter and his World. Vase Painting in Sixth-Century B.C. Athens, Malibu.

Bothmer, Dietrich von (1987), Greek Vase Painting, rev. edn., New York.

Bothmer, Dietrich von (ed.) (1990), Glories of the Past: Ancient Art from the Shelby White and Leon Levy Collection, Exhibition Catalogue New York, Metropolitan Museum of Art, New York.

Bothmer, Dietrich von/Mertens, Joan R. (1979), Greek Art of the Aegean Islands, Exhibition Catalogue, New York.

Bottini, Angelo (2011), “Tra metallo e ceramica. Trasmissione di forme e di elementi decorative: Due studie," Bolletino di Archeologia On Line 2.1, 1-13.

Boudon-Millot, Véronique (1994), "Le rôle de l'eau dans les prescriptions médicales d’Asclépios chez Galien et Aelius Aristide," in René Ginouvès et al. (eds.), L'eau, la santé et la maladie dans le monde grec, Actes du colloque organisé à Paris (CNRS et Fondation Singer-Polignac) du 25-27 novembre 1992, BCH Supplement 28, Paris, 157-168.

Boulter, Cedric G./Bentz, Julie L. (1980), “Fifth-century Attic Red Figure at Corinth,” Hesperia 49, 295-308.

Bouvier, Michel (2000), Le lièvre dans l'antiquité, Lyon.

Bowersock, Glen W. (1984), "Augustus and the East: The Problem of Succession," in Fergus Millar/ Erich Segal (eds.), Caesar Augustus: Seven Aspects, Oxford, 169-188.

Bowra, Maurice (1963), "Arion and the Dolphin," $M H$ 20, 121-134.

Brann, Eva (1960), “Late Geometric Grave Groups from the Athenian Agora," Hesperia 29, 402-416.

Brann, Eva T. H. (1971), Late Geometric and Protoattic Pottery, The Athenian Agora 8, Princeton.

Brelich, Angelo (1955), Tre variazioni romane sul tema delle origini, Rome.

Brelich, Angelo (1955-57), “Les monosandales," La nouvelle Clio 7-9, 469-484.

Brelich, Angelo (1958), Gli eroi greci. Un problema storico-religioso, Rome.

Bremmer, Jan (1978), “Heroes, Rituals and the Trojan War," SSR 2, 5-38.

Brewer, James Norris (1826), Beauties of Ireland, Vol. 2, London.

Brijder, H. A. G. (1983), Siana Cups I and Komast Cups, 2 vols., Allard Pierson Series 4, Amsterdam.

Brijder, H. A. G. (1991), Siana Cups II. The Heidelberg Painter, 2 vols., Allard Pierson Series 8, Amsterdam.

Brize, Philip (1980), Die Geryoneis des Stesichoros und die frühe griechische Kunst, Beiträge zur Archäologie 12, Würzburg.

Brommer, Frank (1942a), "Gefässformen bei Homer," Hermes 77, 356-373.

Brommer, Frank (1942b), "Herakles und die Hesperiden auf Vasenbildern,” JDAl 57, 105-123.

Brommer, Frank (1949), "Herakles und Hydra auf attischen Vasenbildern," Marburger WinckelmannProgramm, 3-8.

Brommer, Frank (1959), Satyrspiele: Bilder griechischer Vasen, Berlin.

Brommer, Frank (1961), “Die Geburt der Athena,” JRGZ 8, 66-83.

Brommer, Frank (1967), Die Metopen des Parthenon. Katalog und Untersuchung, Mainz. 
Brommer, Frank (1973), Vasenlisten zur griechischen Heldensagen, $3^{\text {rd }}$ edn., Marburg.

Brommer, Frank (1979), “Theseus-Deutungen,” $A A$, 487-512.

Brommer, Frank (1982), Theseus. Die Taten des griechischen Helden in der antiken Kunst und Literatur, Darmstadt.

Brommer, Frank (1985), “Herakles und Theseus auf Vasen in Malibu," Greek Vases in the J. Paul Getty Museum 2, Malibu, 183-228.

Brommer, Frank (1986), Heracles: The Twelve Labors of the Hero in Ancient Art and Literature, trans. and enlarged by Shirley J. Schwarz, New Rochelle.

Brouskari, Maria S. (1974), The Acropolis Museum. A Descriptive Catalogue, Athens.

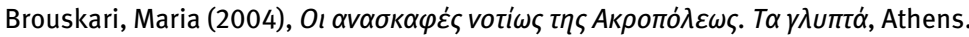

Brown, Blanche R. (1981), “Novelty, Ingenuity, Self-aggrandizement, Ostentation, Extravagance, Gigantism, and Kitsch in the Art of Alexander the Great and his Successors," in Moshe Barasch et al. (eds.), Art, the Ape of Nature: Studies in honor of H. W. Janson, New York, 1-13.

Brown, Norman Oliver (1947), Hermes the Thief. The Evolution of a Myth, Madison.

Brownlee, A. Blair (1997), “Antimenean Dinoi,” in John H. Oakley/William D. E. Coulson/Olga Palagia (eds.), Athenian Potters and Painters I, The Conference Proceedings, Oxford, 509-522.

Brownlee, A. Blair (2003), "Attic Black-figured Vases from Orvieto in the University of Pennsylvania Museum," in Bernhard Schmaltz/Magdalene Söldner (eds.), Griechische Keramik im kulturellen Kontext, Akten des Internationalen Vasen-Symposions in Kiel vom 24.-29.9.2001, Münster, 217-219.

Brulotte, Eric Lucien (1994), “The 'Pillar of Oinomaos' and the Location of Stadium I at Olympia,” AJA 98, 53-64.

Brun, Jean-Pierre (2011), “La produzione del vino in Magna Grecia e in Sicilia,” in La vigna di Dioniso. Vite, vino e culti in Magna Grecia, Atti del quarantanovesimo Convegno di Studi sulla Magna Grecia, Taranto 24-28 settembre 2009, Taranto, 95-142.

Brun, Jean-Pierre/Poux, Matthieu/Tchernia, André (eds.) (2004), Le vin, nectar des dieux, génie des hommes, Gollion.

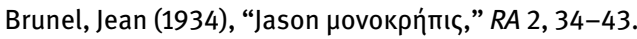

Bruno, Vincent J. (1969), “Antecedents of the Pompeian First Style," AJA 73, 305-317.

Bruns, Gerda (1964), "Kabirenheiligtum bei Theben. Vorläufiger Bericht über die Grabungskampagnen 1959 und 1962," $A A, 231-266$.

Bruschetti, Paolo (1984), “Il motivo del taglio di un ricciolo. Contributo alla esegesi di un gesto," in Maria Grazia Marzi Costagli/Luisa Tamagno Perna (eds.), Studi di antichità in onore di Guglielmo Maetzke, Rome, 151-159.

Buitron, Diana/Cohen, Beth (eds.) (1992), The Odyssey and Ancient Art: An Epic in Word and Image, Exhibition Catalogue, Edith C. Blum Art Institute, Annandale-on-Hudson, NY.

Buitron-Oliver, Diana (1972), Attic Vase Painting in New England Collections, Cambridge, MA.

Buitron-Oliver, Diana (1995), Douris, a Master-painter of Athenian Red-figure Vases, Mainz.

Buitron-Oliver, Diana/Cohen, Beth (1995), "Between Skylla and Penelope: Female Characters of the Odyssey in Archaic and Classical Greek Art," in Beth Cohen (ed.), The Distaff Side: Representing the Female in Homer's Odyssey, New York/Oxford, 29-58.

Bulas, Casimir (1932), "Études sur un classe de vases à décor en forme de réseau ou d'écailles," BCH 56, 388-398.

Bundrick, Sheramy (2005), Music and Image in Classical Athens, Cambridge.

Bundrick, Sheramy (2008), "The Fabric of the City: Imaging Textile Production in Classical Athens," Hesperia 77, 283-334.

Bundrick, Sheramy (2014), “Under the Tuscan Soil: Reuniting Attic Vases with an Etruscan Tomb," in John H. Oakley (ed.), Athenian Potters and Painters III, The Conference Proceedings, Oxford/ Oakville, 11-21. 
Burford, Alison (1969), The Greek Temple Builders at Epidauros. A Social and Economic Study of Building in the Asclepian Sanctuary during the $4^{\text {th }}$ and $3^{\text {rd }}$ cent. B.C., Liverpool.

Burgess, Jonathan S. (1997), "Beyond Neo-Analysis: Problems with the Vengeance Theory," AJPh 118, 1-19.

Burgess, Jonathan S. (2001), The Tradition of the Trojan War in Homer and the Epic Cycle, Baltimore.

Burgess, Jonathan S. (2004), "Early Images of Achilles and Memnon?," QUCC 76, 33-51.

Burke, Bernard (1855), A Visitation of the Seats and Arms of the Noblemen and Gentlemen of Great Britain and Ireland, London.

Burkert, Walter (1966), "Kekropidensage und Arrhephoria: Vom initiationsritus zum Panathenäenfest," Hermes 94, 1-25.

Burkert, Walter (1983), Homo Necans. The Anthropology of Greek Sacrificial Ritual and Myth, trans. by Peter Bing, Berkeley.

Burkert, Walter (1985), Greek Religion. Archaic and Classical, trans. by J. Raffan, Oxford.

Burkert, Walter (2012), "Der Abschluss der Ilias im Zeugnis korinthischer und attischer Vasen (580/560 v. Chr.)," Museum Helveticum 69, 1-11.

Burn, Lucilla M. (1988), "A Heron on the Left, by the Kodros Painter," in Jette Christiansen/Torben Melander (eds.), Proceedings of the $3^{\text {rd }}$ Symposium on Ancient Greek and Related Pottery, Copenhagen, 99-106.

Burn, Lucilla M. (2010), "The Contexts of the Production and Distribution of Athenian Painted Pottery around 400 BC," in Oliver Taplin/Rosie Wyles (eds.), The Pronomos Vase and its Context, Oxford, $15-31$.

Burow, Johannes (1989), Der Antimenesmaler, Kerameus 7, Mainz.

Busuttil, J. (1969), “The Maltese Dog,” G\&R16, 205-208.

Cahn, H. A. (Herbert A.) (1973), “Dokimasia,” RA, 3-22.

Cairns, Douglas L. (1996), "Veiling, aỉō̃ $\varsigma$ and a Red-figure Amphora by Phintias," JHS 116, 152-158.

Calame, Claude (1990), Thesée et l'imaginaire athénien. Légende et cult en Grèce antique, Lausanne.

Calame, Claude (2009), "Thésée l’Athénien au Metropolitan Museum of Art de New York: Scènes étiologiques de légitimation et questions de méthode," in Dimitrios Yatromanolakis (ed.), An Archaeology of Representations. Ancient Greek Vase-painting and Contemporary Methodologies, Athens, 98-127.

Callipolitis-Feytmans, Denise (1976), “Les aryballes à pied en Attique et leurs rapports avec Corinthe,” BCH 100, 137-158.

Camp, John McK. (1992), The Athenian Agora: Excavations in the Heart of Classical Athens, New York.

Camp, John McK. (2003), “Excavations in the Athenian Agora: 1998-2001,” Hesperia 72, 241-280.

Campbell, David A. (1991), Greek Lyric III: Stesichorus, Ibycus, Simonides, and Others, Cambridge, MA.

Cancik, Hubert (1997), “Die 'Repraesentation' von ‘Provinz' (nationes, gentes) in Rom. Ein Beitrag zur Bestimmung von 'Reichsreligion' vom 1. Jahrhundert v. Chr. bis zum 2. Jahrhundert n. Chr.," in Hubert Cancik/Jörg Rüpke (eds.), Römische Reichsreligion und Provinzialreligion, Tübingen, 129-143.

Cantarelli, Luigi (1904), “Un prefetto di Egitto zio di Seneca," $\operatorname{MDAI(R)~19,~15-22.~}$

Carlier, Pierre (2005), "Les rois d'Athènes. Étude sur la tradition," in Emanuele Greco (ed.), Teseo $e$ Romolo. Le origini di Atene e Roma a confronto, Atti del Convegno Internazionale di Studi: Scuola Archeologica Italiana di Atene, Atene, 30 giugno-1 luglo 2003, Athens, 125-141.

Carpenter, Thomas H. (1982), “On the Dating of the Tyrrhenian Group,” OJA 2, 279-293.

Carpenter, Thomas H. (1986), Dionysian Imagery in Archaic Greek Art: Its Development in Black-Figure Vase Painting, Oxford.

Carpenter, Thomas H. (1991), Art and Myth in Ancient Greece. A Handbook, London/New York. 
Carpenter, Thomas H. (1993), “On the Beardless Dionysus," in Thomas H. Carpenter/Christopher Faraone (eds.), Masks of Dionysus, Ithaca, NY, 185-206.

Carpenter, Thomas H. (1997), Dionysian Imagery in Fifth-Century Athens, Oxford.

Carter, Jane B. (1989), "The Chests of Periander," AJA 93, 355-378.

Caruso, Christiane (1987), "Travestissements dionysiaques," in Claude Bérard/Christiane Bron/Alessandra Pomari (eds.), Images et société en Grèce ancienne: L'iconographie comme méthode d'analyse, Lausanne, 103-110.

Cashen, Patricia (1986), Valentine Lord Cloncurry and his Collection at Lyons House, M.A. Thesis, University College Dublin.

Caskey, Lacey D./Beazley, J. D. (John Davidson) (1954), Attic Vase Paintings in the Museum of Fine Arts, Boston II, Oxford.

Castellvi, Georges/Nolla, Josep M./Roda, Isabel (1995), “La identificacíon de los trofeos de Pompeyo en el Pirineo," JRA 8, 5-18.

Castiglione Morelli, Vincenzina (1996), “Cratere con scene a rilievo," in Maria Rosaria Borriello et al. (eds.), Pompei. Abitare sotto il vesuvio, Catalogue, Ferrara, 235.

Cateni, Gabriele (1991), Volterra. Guarnacci Museum, Pisa.

Cateni, Gabriele (2004), Volterra. Museo Guarnacci, Pisa.

Cerulli Irelli, Giuseppina (1981), Le case di M. Fabio Rufo e di C. Giulio Polibio, in Pompei 1748-1980. I tempi della documentazione, Rome, 22-33.

Chantraine, Pierre (1999), Dictionnaire étymologique de la langue grecque: Histoire des mots, $2^{\text {nd }}$ edn., Paris.

Charbonneaux, Jean/Martin, Roland/Villard, François (1978), La Grecia ellenistica (330-50 a.C.), Reprint [1971], Milan.

Charles-Picard, Gilbert (1957), Les trophées romains. Contribution à l'histoire de la religion et de l'art triomphal de Rome, Rome.

Chase, George (1902), "The Shield Devices of the Greeks," HSPh 13, 61-127.

Chiasson, Charles (2005), “Myth, Ritual, and Authorial Control in Herodotus' Story of Cleobis and Biton (Hist. 1.31)," AJP 126, 41-64.

Chioffi, Laura (1999), Caro: Il mercato della carne nell'occidente romano. Riflessi epigrafici ed iconografici, Rome.

Ciardiello, Rosaria (2007), “Teseo nella ceramica attica: Alcune osservazioni intorno ad un libro recente," Prospettiva 126-127, 179-189.

Ciasca, Antonia et al. (1969), Mozia: Rapporto preliminare della Missione archeologica della Soprintendenza alle antichità della Sicilia occidentale e dell'Università di Roma, $V$, Rome.

Ciasca, Antonia et al. (1989), Mozia, Itinerari 4, Rome.

Cimatu, Frank/Santos-Doctor, Joya (2003), “Philippines' 'Ozymandias' Still Haunts,” Philippines Daily Inquirer, January 1, 2003, 1-2.

Clairmont, Christoph W. (1951), Das Parisurteil in der antiken Kunst, Zurich.

Clairmont, Christoph W. (1993-95), Classical Attic Tombstones, 9 vols., Kilchberg/Zurich.

Clark, Andrew J./Elston, Maya/Hart, Mary Louise (2002), Understanding Greek Vases: A Guide to Terms, Styles, and Techniques, Los Angeles.

Clay, Diskin (2004), Archilochos Heros: The Cult of Poets in the Greek Polis, Washington DC.

Clay, Jenny Strauss (1989), The Politics of Olympus: Form and Meaning in the Major Homeric Hymns, Princeton.

Clay, Jenny Strauss (2011), Homer's Trojan Theater: Space, Vision, and Memory in the lliad, Cambridge. Coche de La Ferté, Etienne (1951), "Les ménades et le contenu réel des représentations de scènes bachiques autour de l'idole de Dionysos," RA 38, 12-23.

Cohen, Beth (1983), "Paragone: Sculpture versus Painting, Kaineus and the Kleophrades Painter,” in Warren G. Moon (ed.), Ancient Greek Art and Iconography, Madison, 171-192. 
Cohen, Beth (1997), “Red-figure Vases Take Wing” in John H. Oakley/William D. E. Coulson/ Olga Palagia (eds.), Athenian Potters and Painters I, The Conference Proceedings, Oxford, 141-155.

Cohen, Beth et al. (2006), The Colors of Clay: Special Techniques in Athenian Vases, Los Angeles.

Collard, Christopher/Cropp, Martin (eds.) (2008), Euripides. Fragments. Aegeus-Meleager, Cambridge, MA.

Colonna, Giovanni (2003), “Osservazioni sulla Tomba tarquiniese della Nave,” in Alessandra Minetti (ed.), Pittura etrusca: Problemi e prospettive, Atti del Convegno Sarteano-Chiusi, 26-27 ottobre 2001, Siena, 63-77.

Connolly, Peter/Dodge, Hazel (1998), The Ancient City. Life in Classical Athens and Rome, Oxford.

Connor, W. Robert (1994), “The Problem of Athenian Civic Identity,” in Alan L. Boegehold/Adele

C. Scafuro (eds.), Athenian Identity and Civic Ideology, Baltimore, 34-44.

Conti, Maria Clara (2012), Le terrecotte architettoniche di Selinunte. Tetti del VI e V secolo a.C., Pisa/ Rome.

Cook, Arthur B. (1895), “The Bee in Greek Mythology,”JHS 15, 1-24.

Cook, John M. (1973), The Troad: An Archaeological and Topographical Study, Oxford.

Cook, Robert M. (1960), Greek Painted Pottery, London/New York.

Cook, Robert M. (1981), Clazomenian Sarcophagi, Mainz.

Cook, Robert M. (1983), “Art and Epic in Archaic Greece,” BABesch 58, 1-10.

Cook, Robert M./Dupont, Pierre (2003), East Greek Pottery, London/New York.

Cooper, Craig (2007), “Making Irrational Myth Plausible History: Polybian Intertextuality in Plutarch's Theseus," Phoenix 61, 212-233.

Cooper, John (2005), “Political Animals and Civic Friendship,” in Richard Kraut/Steven Skultety (eds.), Aristotle's Politics: Critical Essays, Lanham, MD, 65-89.

Cornu, Georgette/Martiniani-Reber, Marielle/Ritschard, Claude (1993), Tissus d'Égypte. Témoins du monde arabe VIII $-X V$ siècles: Collection Bouvier, Geneva/Paris.

Costaki, Leda (2006), The intra muros Road System ofAncient Athens, Ph.D. Diss., University of Toronto.

Coulton, J. J. (1976), The Architectural Development of the Greek Stoa, Oxford.

Crawford, Michael H. (1974), Roman Republican Coinage, Cambridge.

Croissant, Francis (1988), “Tradition et innovation dans les ateliers corinthiens archaïques: Matériaux pour l'histoire d'un style,” BCH 112, 91-166.

Cromey, Robert David (1991), “History and Image: The Penelope Painter's Akropolis (Louvre G372 and 480/79 BC),"JHS 111, 165-174.

Croon, H. Johan (1955), "The Mask of the Underworld Daemon - Some Remarks on the Perseus-Gorgon Story," JHS 75, 9-16.

Crowther, Nigel B. (1994), "The Role of Heralds and Trumpeters at Greek Athletic Festivals," Nikephoros 7, 135-155.

Cruciani, Claudia/Fiorini, Lucio (1998), I modelli del moderato. La Stoà Poikile e l'Hephaisteion di Atene nel programma edilizio cimoniano, Naples.

Csapo, Eric (1997), “Riding the Phallus for Dionysus: Iconology, Ritual, and Gender-Role De/Construction," Phoenix 51, 253-295.

Csapo, Eric (2013), “Comedy and the Pompe. Dionysian genre-crossing," in Emmanuela Bakola/Lucia Prauscello/Mario Telò (eds.), Greek Comedy and the Discourse of Genres, Cambridge, 40-80.

Cutroni Tusa, Aldina (1969), “Mozia: Monetazione e circolazione,” in Antonia Ciasca et al., Mozia: Rapporto preliminare della Missione archeologica della Soprintendenza alle antichità della Sicilia occidentale e dell'Università di Roma, $V$, Rome, 97-119.

D’Ambra, Eve (2007), "Racing with Death: Circus Sarcophagi and the Commemoration of Children in Roman Italy," in Ada Cohen/Jeremy B. Rutter (eds.), Constructions of Childhood in Ancient Greece and Italy, Hesperia Supplement 41, Princeton, 339-351. 
D’Amicis, Amalia (2013), “Una lekythos a rilievi policromi con scena di Adonie da Taranto," in Giuseppe Andreassi et al. (eds), Vetustis novitatem dare. Temi di antichità e archeologia in ricordo di Grazia Angela Maruggi, Arbor Sapientiae, Taranto, 499-509.

D’Angour, Armand (1997), "How the Dithyramb Got its Shape," CQ 47, 331-351.

Dagi, Marianne (2003), “'Tinkers' and 'Patchers': Some Notes on the Ancient Repairs of Greek Vases,” BullMusHongr 99, 31-66.

Daltrop, Georg (1966), Die kalydonische Jagd in der Antike, Hamburg.

Danek, Georg (2005), “Antenor und die Bittgesandtschaft. Ilias, Bakchylides 15 und der Astaritakrater," WS 118, 5-20.

Davidson, James N. (1997), Courtesans and Fishcakes. The Consuming Passions of Classical Athens, New York.

Davidson, James N. (2007), The Greeks and Greek Love: A Bold New Exploration of the Ancient World, New York.

Davie, John N. (1982), “Theseus the King in Fifth-century Athens," G\&R 29, 25-34.

Davies, Glenys (2007), The Ash Chests and Other Funerary Reliefs. The Ince Blundell Collection of Classical Sculpture 2, Mainz.

Davies, Glenys (2008), “Portrait Statues as Models for Gender Roles in Roman Society," Sinclair Bell/ Inge Lyse Hansen (eds.), Role models in the Roman World: Identity and Assimilation, Ann Arbor, 207-220.

Davies, Malcolm (2000), "Euripides Telephus fr. 149 (Austin) and the Folk-Tale Origins of the Teuthranian Expedition," ZPE 133, 7-10.

Davies, Mark (1977), "The Reclamation of Helen," AK 20, 73-85.

Davis, Jack (2000), "Warriors for the Fatherland: National Consciousness and Archeology in "Barbarian' Epirus and 'Verdant' Ionia, 1912-22," JMA 13, 76-98.

De Caro, Stefano (1978), “Attività archeologica. Pompei," CronPompeiane 4, 230-231.

De Franciscis, Alfonso (1988), “La casa di C. lulius Polybius," RSP 2, 15-36.

De Salvia, Fulvio (1987), "Una lucerna della fabbrica di M. Novius Iustus al Museo Civico Archeologico di Padova: Fortuna o Iside-Fortuna?," Bolletino del Museo Civico di Padova 76, 7-15.

De Sanctis, Davide (2005), “Labyrinths of Childhood," Childhood and Society 1, 30-38.

De Waele, Jos A. (1971), Acragas Graeca, Die historische Topographie des griechischen Akragas auf Sizilien, Vol. 1, The Hague.

Délcourt, Marie (1944), Oedipe ou la légend du conquérant, Liège.

Delivorrias, Angelos (2005), "Ein klassischer Statuentypus des Poseidon," in Volker Michael Strocka (ed.), Meisterwerke. Internationales Symposion anläßlich des 150. Geburtstages von Adolph Furtwängler, Freiburg im Breisgau 30. Juni-3. Juli 2003, Munich, 157-167.

Delorme, Jean (1960), Gymnasion. Étude sur les monuments consacrés a l'éducation en Grèce (des origines à l'empire romain), Paris.

Demand, Nancy (1994), Birth, Death, and Motherhood in Classical Greece, Baltimore.

Dentzer, Jean-Marie (1982), Le motif du banquet couché dans le Proche-Orient et le monde grec du VIle au IV siècle avant J.C., Paris.

Deonna, Walter (1935), “Моvокри́пıðєৎ,” RHR 112, 50-72.

Depew, David J. (1995), "Humans and Other Political Animals in Aristotle’s History of Animals," Phronesis 40, 156-181.

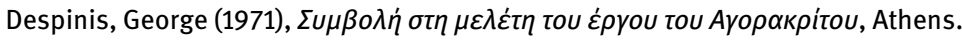

Despinis, George (2005), "Zur Hermes-Statuette im Akropolis Museum Inv. 1346," in Thomas Ganschow/Matthias Steinhart (eds.), Otium: Festschrift für Volker Michael Strocka, Remshalden, 71-74.

Despinis, George (2007), “Neues zu der spätarchaischen Statue des Dionysos aus Ikaria,” $\operatorname{MDAI}(A) 122,103-137$. 
Detienne, Marcel (1986), Dionysos à ciel ouvert, Paris.

Detienne, Marcel (1989a), "Culinary Practices and the Spirit of Sacrifice," in Marcel Detienne/JeanPierre Vernant (eds.), The Cuisine of Sacrifice Among the Greeks, trans. by Paula Wissing, Chicago, 1-20.

Detienne, Marcel (1989b), Dionysos at Large, trans. by Arthur Goldhammer, Cambridge MA.

Detienne, Marcel (1994), The Gardens of Adonis: Spices in Greek Mythology, trans. by Janet Lloyd, $2^{\text {nd }}$ edn., with an introduction by Jean-Pierre Vernant and a new afterword by the author, Princeton.

Deubner, Ludwig A. (1932), Attische Feste, Berlin.

Devambez, Pierre (1972), “Une 'arula’ sicilienne au Louvre,” MMA/ 58, 1-23.

Devambez, Pierre (1976), "Les Amazones et l'Orient," RA, 265-280.

Devereux, George (1976), Dreams in Greek Tragedy: An Ethno-psycho-analytical Study, Berkeley.

DeVries, Keith (1997), “The 'Frigid Eromenoi' and Their Wooers Revisited: A Closer Look at Greek Homosexulaity in Vase Painting," in Martin Duberman (ed.), Queer Representations: Reading Lives, Reading Cultures, New York, 14-24.

Di Filippo Balestrazzi, Elena (2011), “Un tema 'omerico' nella situla di Welzelach?,” in Tra protostoria e storia. Studi in onore di Lorendana Capuis, Treviso, 223-244.

Di Vita, Antonio (1959), “Due vasi attici della prima metà del VI sec. A.C.,” BA 44, 293-310.

Di Vita, Antonio (1988), "La statua di Mozia," in Nicola Bonacasa/Antonino Buttitta (eds.), La statua marmorea di Mozia e la scultura di stile severo in Sicilia, Atti della giornata di studio, Marsala, 1 giugno 1986, Rome, 39-52.

Diehl, Erika (1964), Die Hydria. Formgeschichte und Verwendung im Kult des Altertums, Mainz.

Dietrich, Nikolaus (2010), Figur ohne Raum? Bäume und Felsen in der attischen Vasenmalerei des 6. und 5. Jahrhunderts v. Chr., Berlin.

Dillon, Matthew (1994), “The Didactic Nature of the Epidaurian Iamata," ZPE 101, 239-260.

Dillon, Matthew (2001), Girls and Women in Classical Greek Religion, London/New York.

Dimas, Stephanie (1998), Untersuchungen zur Themenwahl und Bildgestaltung aufrömischen Kindersarkophagen, Münster.

Dinsmoor, William Bell (1975), The Architecture of Ancient Greece, $3^{\text {rd }}$ edn., New York.

Dintsis, Petros (1986), Hellenistische Helme, Rome.

Dipla, Anthi (1997), “Helen, the Seductress?,” in Olga Palagia (ed.), Greek Offerings: Essays on Greek Art in Honour of John Boardman, Oxford, 119-130.

Dohrn, Tobias (1977), “Helden und die Höhle,” $\operatorname{MDAI}(R)$ 84, 211-234.

Donnay, Guy (1997), “L’arrhéphorie: Initiation ou rite civique? Un cas d'école,” Kernos 10, 177-205.

Donohue, Alice A. (1988), Xoana and the Origins of Greek Sculpture, Atlanta.

Dontas, Giorgios (1988), “Un'opera siceliota, l'auriga di Mozia," in Nicola Bonacasa/Antonino Buttitta (eds.), La statua marmorea di Mozia e la scultura di stile severo in Sicilia, Atti della giornata di studio, Marsala, 1 giugno 1986, Rome, 61-68.

Dorman, Peter F. (1988), The Monuments of Senenmut: Problems in Historical Methodology, London. Dover, Kenneth J. (1978), Greek Homosexuality, Cambridge, MA.

Dowden, Ken (1997), “The Amazons: Development and Functions," RhM 140, 97-128.

Ducrey, Pierre/Metzger, Ingrid R./Reber, Karl (1993), Le Quartier de la Maison aux mosaiques, Eretria 8, Lausanne.

Dugas, Charles (1937), “Tradition littéraire et tradition graphique dans l'antiquité grecque,” AC 6, 5-26. Dugas, Charles/Flacelière, Robert (1958), Thésée. Images et récits, Paris.

Dümmler, Georg Ferdinand (1901), Kleine Schriften, Vol 3: Archäologische Aufsätze, Leipzig.

Dumont, Jacques (2001), Les animaux dans l'antiquité grecque, Paris.

Dunbabin, Katherine M. (1999), Mosaics of the Greek and Roman World, Cambridge.

Dunbabin, T. J. (Thomas James) (1948), The Western Greeks. The History of Sicily and South Italy from the Foundation of the Greek Colonies to 480 B.C., Oxford. 
Dunbabin, T. J. (Thomas James) (1950), “An Attic Bowl,” ABSA 45, 193-202.

Durand, Jeanmart (1992), “'L'Hermès Multiple,” in Christianne Bron/Effy Kassapoglou (eds.), L'Image en jeu: De l'antiquité à Paul Klee, Lausanne, 25-34.

Dyer, Thomas Henry (1873), Ancient Athens, Its History, Topography and Remains, London.

Ebbinghaus, Susanne (2005), "Protector of the City, or the Art of Storage in Early Greece," JHS 125, 51-72.

Edmunds, Lowell (1984), “Thucydides on Monosandalism (3.22.2)," in Alan L. Boegehold et al. (eds.), Studies Presented to Sterling Dow on his Eightieth Birthday, Durham, 71-75.

Edwards, G. Roger (1975), Corinthian Hellenistic Pottery, Corinth VII.3, Princeton.

Edwards, Mary D./Bailey, Elizabeth (2012), "Introduction," in Mary D. Edwards/Elizabeth Bailey (eds.), Gravity in Art: Essays on Weight and Weightlessness in Painting, Sculpture and Photography, Jefferson, NC, 1-9.

Eiffe, June (1984), “Lyons, Co. Kildare," Bulletin of the Irish Georgian Society 27, 1-37.

Ekroth, Gunnel (2010), "Theseus and the Stone. The Iconographic and Ritual Contexts of a Greek Votive Relief in the Louvre," in Joannis Mylonopoulos (ed.), Divine Images and Human Imaginations in Ancient Greece and Rome, Leiden, 143-169.

Else, Gerald (1965), The Origin and Form of Early Greek Tragedy, Cambridge, MA.

Engster, Dorit (2003), “Römisches Frauenlob und Polyandrie: Die Grabinschrift der Allia Potestas,” AKG 85, 143-169.

Erskine, Andrew (2001), Troy between Greece and Rome: Local Tradition and Imperial Power, Oxford.

Eschbach, Norbert (1986), Statuen auf Panathenäischen Preisamphoren des 4. Jhs. v. Chr., Mainz.

Eschbach, Norbert (2007), "Teile und verdiene: Zu den Wanderbewegungen attischer Keramik um 1900," in Martin Bentz/Ursula Kästner (eds.), Konservieren oder Restaurieren: Die Restaurierung griechischer Vasen von der Antike bis heute, CVA Beiheft 3, Munich, 83-92.

Espermann, Ingeborg (1980), Antenor, Theano, Antenoriden: Ihre Person und Bedeutung in der Ilias, Meisenheim.

Evans, Nancy (2010), Civic Rites: Democracy and Religion in Ancient Athens, Berkeley/Los Angeles. Evelyn-White, Hugh G. (trans.) (1914), Hesiod, The Homeric Hymns, and Homerica, Cambridge, MA. Falbusch, Gerlinde (2004), Die Frauen im Gefolge des Dionysos auf den attichen Vasenbildern des 6. und 5. Jhs v. Chr. als Spiegel des weiblichen Idealbildes, BAR International Series 1322, Oxford.

Fales, DeCoursey Jr. (1960), “An Unpublished Fragment Attributed to Kleitias,” AJA 67, 211.

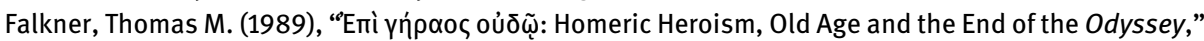
in Thomas M. Falkner/Judith de Luce (eds.), Old Age in Greek and Latin Literature, Albany, NY, 21-67.

Falkner, Thomas M. (1995), The Poetics of Old Age in Greek Epic, Lyric, and Tragedy, Norman, OK.

Falsone, Gioacchino (1988), "La scoperta, lo scavo e il contesto archeologico," in Nicola Bonacasa/ Antonino Buttitta (eds.), La statua marmorea di Mozia e la scultura di stile severo in Sicilia, Atti della giornata di studio, Marsala, 1 giugno 1986, Rome, 9-28.

Famà, Maria Luisa (2013), “The Mozia Charioteer," in Claire L. Lyons/Michael Bennett/Clemente Marconi (eds.), Sicily: Art and Invention between Greece and Rome, Malibu, 84.

Fantuzzi, Marco (2012), Achilles in Love: Intertextual Studies, Oxford.

Faustoferri, Amalia (1986), "Tentativo d'interpretazione dei soggetti raffigurati all'interno delle coppe laconiche del VI sec. a.C.," in Studi sulla ceramica laconica, Atti del Seminario Perugia 23-24 febbraio 1981, Rome, 119-147.

Fehr, Burkhard (2009), "Pornos and the Pleasure of Rest: Some Thoughts on Body Language in Ancient Greek Art and Life," in Dimitrios Yatromanolakis (ed.), An Archaeology of Representations. Ancient Greek Vase-Painting and Contemporary Methodologies, Athens, 128-158.

Fergola, Lorenzo (2003), “I reperti della Casa di Giulio Polibio nel loro contesto originario," in Antonio D’Ambrosio/Piero Giovanni Guzzo/Marisa Mastroroberto (eds.), Storie da un'eruzione. Pompei, Ercolano, Oplontis, Catalogue, Milan, 425. 
Ferrari, Gloria (1988), I vasi attici a figure rosse del periodo arcaico, Materiali del Museo Archeologico Nazionale di Tarquinia 11, Rome.

Ferrari, Gloria (2003), "Myth and Genre on Athenian Vases," ClAnt 22, 37-54.

Ferris, lain M. (2000), Enemies of Rome: Barbarians through Roman Eyes, Stroud.

Filow, Bogdan (1927), Die archaische Nekropole von Trebenischte am Ochrida-See, Berlin.

Finglass, Peter J. (2013), “Demophon in Egypt,” ZPE 184, 37-50.

Finster-Hotz, Ursula (1984), Der Bauschmuck des Athenatempels von Assos. Studien zur Ikonographie, Rome.

Fischer-Hansen, Tobias (1973), “To siciliske arulae,” Meddelelser fra Ny Carlsberg Glyptotek 30, Copenhagen, 61-88.

Fittschen, Klaus (1969), Untersuchungen zum Beginn der Sagendarstellungen bei den Griechen, Berlin.

Fittschen, Klaus (1992), "Der Tod der Kreusa und der Niobiden: Überlegungen zur Deutung griechischer Mythen auf römischen Sarkophagen," SIFC 10, 1046-1059.

Fittschen, Klaus/Zanker, Paul (1985), Katalog der römischen Porträts in den Capitolinischen Museen und den anderen kommunalen Sammlungen der Stadt Rom, Vol. 1, Mainz.

Fiumi, Enrico (1978), Volterra. Il Museo Etrusco e i monumenti antichi, Pisa.

Flashar, Martin/von den Hoff, Ralf/Kreuzer, Bettina (2003), Theseus. Der Held der Athener, Exhibition Catalogue Freiburg im Breisgau, Munich.

Flemming, Rebecca (2013), "Baths and Bathing in Greek Medicine," in Sandra K. Lucore/Monika Trümper (eds.), Greek Baths and Bathing Culture: New Discoveries and Approaches, BABesch Supplement 23, Leuven, 23-32.

Forbes Irving, P. M. C. (1990), Metamorphosis in Greek Myths, Oxford.

Forbis, Elizabeth (1990), “Women's Public Image in Italian Honorary Inscriptions,” AJPh 111, 493-512.

Formigé, Jules (1949), Le trophée des Alpes (La Turbie), Paris.

Fornasier, Jochen (2007), Amazonen: Frauen, Kämpferinnen und Städtegründerinnen, Mainz.

Förtsch, Reinhard (2001), Kunstverwendung und Kunstlegitimation im archaischen und frühklassischen Sparta, Mainz.

Fortunelli, Fabrizia/Manca di Mores, Giuseppina (1986), “Il pittore dei Boreadi,” in Fernanda Pampili (ed.), Studi sulla ceramica laconica, Atti del Seminario Perugia 1981, Rome, 21-26.

Fortunelli, Simona (ed.) (2005), Il museo della città etrusca e romana di Cortona. Catalogo delle collezioni, Florence.

Foster, Patricia (1978), Greek Arms and Armour, Newcastle-upon-Tyne.

Foxhall, Lin (2011), "Produzione e commercio del vino in Grecia," in La vigna di Dioniso. Vite, vino e culti in Magna Grecia, Atti del quarantanovesimo convegno di studi sulla Magna Grecia, Taranto 24-28 settembre 2009, Taranto, 33-51.

Franzoni, Claudio (2006), Tirannia dello sguardo. Corpo, gesto, espressione dell'arte greca, Turin.

Fraser, Peter Marshall/Matthews, Elaine (eds.) (1997), A Lexicon of Greek Personal Names, Vol. IIIA, Oxford.

Frazer, James G. (1913), Pausanias's Description of Greece, 6 vols., London.

Frazer, James G. (1921), Apollodorus: The Library, 2 vols., Cambridge, MA.

Frel, Jiři (1977), “The Kleophrades Painter in Malibu," GMusJ 4, 63-76.

Frel, Jiří (1985), “L’auriga di Mozia. Un’opera di Pitagora di Reggio,” PP 40, 64-68.

Frey, Otto-Herman (2011), “The World of Situla Art,” in Larissa Bonfante (ed.), The Barbarians of Ancient Europe. Realities and Interactions, Cambridge, 282-312.

Frickenhaus, August Heinrich (1912), Lenäenvasen, Berlin.

Friese, Wiebke (2009), “Geliebter Gott oder Göttlicher Geliebter? Adoniskult im Schatten der Aphrodite," in Martina Seifert (ed.), Aphrodite, Herrin des Krieges, Göttin der Liebe, Mainz, 91-110.

Friis Johansen, Knud (1967), The lliad in Early Greek Art, Copenhagen. 
Froehner, Wilhelm (1876), Anatomie des vases antiques, Paris.

Frontisi-Ducroux, Françoise (1991), Le dieu-masque: Une figure du Dionysos d'Athènes. Images à l'appui, Vol. 4, Paris.

Frontisi-Ducroux, Françoise (1997), “Retour aux 'vases des Lénéennes,"” in Benedetto Bravo (ed.), Pannychis e simposio: Feste private notturne di donne e uomini nei testi letterari e nel culto con uno studio iconografico di Françoise Frontisi-Ducroux, Filologia e Critica 79, Pisa, 123-132.

Frontisi-Ducroux, Françoise (1998), “Kalé: Le féminin facultatif,” Métis 13, 173-187.

Frontisi-Ducroux, Françoise/Lissarrague, François (1990), "From Ambiguity to Ambivalence: A Dionysiac Excursion through the 'Anakreontic' Vases," in David Halperin/John J. Winkler/Froma I. Zeitlin (eds.), Before Sexuality: The Construction of Erotic Experience in the Ancient Greek World, Princeton, 211-256.

Frost, Frank J. (1994), "Aspects of Early Athenian Citizenship," in Alan L. Boegehold/Adele C. Scafuro (eds.), Athenian Identity and Civic Ideology, Baltimore, 45-56.

Fuchs, Werner (1982), Storia della scultura greca, trans. by Piero Orlandini, Milan.

Furley, William D. (1996), Andokides and the Herms: A Study of Crisis in Fifth-century Athenian Religion, BICS Supplement 65, London.

Fürstenberg, Michael (2003), Theseus als Nationalheld der Athener, New York/London.

Furtwängler, Adolf (1890), Die Bronzen und die übringen kleineren Funde von Olympia. Olympische Forschungen IV, Berlin.

Furtwängler, Adolf (1906), Aegina. Das Heiligtum der Aphaia, Munich.

Furtwängler, Adolf/Hauser, Friederich/Reichhold, Karl (1932), Griechische Vasenmalerei: Auswahl hervorragender Vasenbilder III, Munich.

Gabelmann, Hanns (1965), Studien zum frühgriechischen Löwenbild, Berlin.

Gaberdan, Daria (2010), “Reparaturen,” in Martin Bentz/Wilfred Geominy/Jan Marius Müller (eds.), TonArt. Virtuosität antiker Töpfertechnik, Eine Ausstellung im Akademischen Kunstmuseum Antikensammlung der Universität Bonn, Petersberg, 104-110.

Gàbrici, Ettore/Tusa, Vincenzo (1956), “Studi archeologici selinuntini,” Monumenti Antichi 43, 205-408.

Gaggadis-Robin, Vassiliki (1994), Jason et Médée sur les sarcophages d'époque impériale, Rome/Paris. Gaifman, Milette (2012), Aniconism in Greek Antiquity, Oxford.

Galinsky, Karl (1969), Aeneas, Sicily, and Rome, Princeton.

Galli, Marco (2004), “'Creating Religious Identities’: Paideia e religione nella Seconda Sofistica,” in Barbara E. Borg (ed.), Paideia: The World of the Second Sophistic, Berlin, 315-356.

Galli, Marco (2005), “Pilgrimage as Elite Habitus: Educated Pilgrims in Sacred Landscape during the Second Sophistic," in Jas Elsner/lan Rutherford (eds.), Pilgrimage in Graeco-Roman and Early Christian Antiquity: Seeing the Gods, Oxford, 253-290.

Gantz, Timothy (1993), Early Greek Myth: A Guide to Literary and Artistic Sources, 2 vols., Baltimore. Garland, Robert (1989), “The Well-Ordered Corpse: An Investigation into the Motives Behind Greek Funerary Legislation," BICS 36, 1-15.

Garland, Robert (2001), The Greek Way of Death, $2^{\text {nd }}$ edn., Ithaca, NY.

Garnsey, Peter (1999), Food and Society in Classical Antiquity, Cambridge.

Gauer, Werner (1984), "Was geschieht mit dem Peplos?," in Ernst Berger (ed.), Parthenon-Kongress Basel, Mainz, 220-229.

Gaunt, Jasper (2003), "Band-Cup with Cheiron, Peleus and Thetis; and Herakles and Nereus," in J. Michael Padgett (ed.), The Centaur's Smile: The Human Animal in Early Greek Art, Exhibition Catalogue, Princeton University Art Museum, New Haven, 343-346.

Gaunt, Jasper (2011), “Review of Louis Godart (ed.), L'Italia e il restauro del Magnifico Cratere. Capolavori del Museo Nazionale di Belgrado, Rome 2010," BA 9, 145-150. 
Gaunt, Jasper (2013a), “Ergotimos Epoiesen. The Potter's Contribution to the François Vase,” in H. A. (H. Alan) Shapiro/Mario lozzo/Adrienne Lezzi-Hafter (eds.), The François Vase. New Perspectives, Papers of the International Symposium, Villa Spelman, Florence, 23-24 May 2003, 2 vols., Kilchberg/Zurich, 67-82.

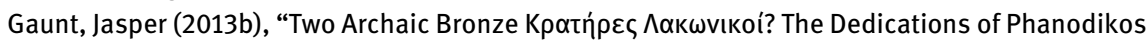
son of Hermokrates of Prokonnesos and of Phalaris Tyrant of Akragas," BABesch 88, 39-54.

Gelder, Koen van (1982), “An Early Archaic Grave from the Cemetery South of the Theatre at Thorikos and the Attribution of TC 64.262 within the Komast Group," in Paule Spitaels (ed.), Studies in South Attica I, Miscellanea Graeca 5, 105-136.

Gentili, Bruno et al. (1995), Pindaro. Le Pitiche. Introduzione, testo critico e traduzione, Milano.

Georgoudi, Stella (2005), “'Athanatous therapeuein’: Réfléxions sur des femmes au service des

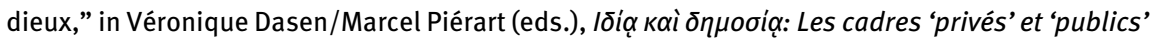
de la religion grecque antique, Kernos Supplement 15, Liège, 69-82.

Gerhard, Eduard (1858), Auserlesene griechische Vasenbilder, Vol. 4: Griechisches Alltagsleben, Berlin.

Gerhard, Eduard (1859), “Griechische Vasenbilder. Campana’s Vasensammlung,” Archäologische Zeitung 17, 137-148.

Germini, Brunella/Ingebor Kader (2006), “Penelope, die Kluge. Geschichte und Deutung einer Frauenfigur,” in Ingebor Kader/Ulrike Koch-Brinkmann (eds.), Penelope rekonstruiert. Geschichte und Deutung einer Frauenfigur, Sonderausstellung des Museums für Abgüsse Klassischer Bildwerke München 9, Oktober bis 15. Januar 2007, Munich, 27-77.

Gessert, Genevieve (2004), “Myth as Consolatio: Medea on Roman Sarcophagi,” G\&R 51, 217-249.

Ghali-Kahil, Lilly (1955), Les enlèvements et le retour d'Hélène dans les textes et les monuments figurés, 2 vols., Paris.

Ghali-Kahil, Lilly (1963), “Quelques vases du sanctuaire d'Artemis à Brauron,” in Neue Ausgrabungen in Griechenland, AK Beiheft 1, Basel, 5-29.

Ghedini, Francesca (1983), “Il Gruppo di Atena e Poseidon sull’ Acropoli di Atene,” RdA 7, 12-36.

Gibert, John (2002), “Recent Work on Greek Satyr Play: Review Article,” CJ 98, 79-88.

Ginouvès, René (1955), "Sur un aspect de l'évolution des bains en Grèce vers le IVe siècle de notre ère," $B C H 79,135-152$.

Ginouvès, René (1962), Balaneutikè. Recherches sur le bain dans l'antiquité grecque, Bibliothèque des Écoles françaises d'Athènes et de Rome 200, Paris.

Ginouvès, René (1994), “L'eau dans les sanctuaires médicaux,” in René Ginouvès et al. (eds.), L'eau, la santé et la maladie dans le monde grec, Actes du colloque organisé à Paris (CNRS et Fondation Singer-Polignac) du 25-27 novembre 1992, BCH Supplement 28, Paris, 237-246.

Ginzburg, Carlo (1998), Storia notturna. Una decifrazione del sabba, Reprint [1989], Turin.

Giudice, Giada/Giudice, Elvia (2011), “Una madre in fuga su una lekythos siciliana,” Ostraka 20, 49-64.

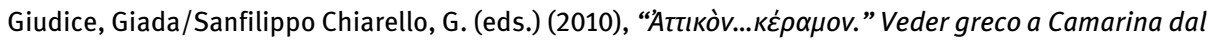
principe di Biscari ai nostri giorni, Catania.

Giuliani, Luca (1988), Bildervasen aus Apulien, Berlin.

Giuliani, Luca (1995), Tragik, Trauer und Trost. Bildervasen für eine apulische Totenfeier, Hannover.

Giuliani, Luca (2003), Bild und Mythos: Geschichte der Bilderzählung in der griechischen Kunst, Munich.

Giuliani, Luca (2004), “Odysseus and Kirke. Iconography in a Pre-literate Culture,” in Clemente Marconi (ed.), Greek Vases: Images, Contexts and Controversies, Proceedings of the Conference Sponsored by The Center for the Ancient Mediterranean at Columbia University, 23-24 March 2002, Leiden, 85-96. 
Giuliani, Luca/Most, Glenn W. (2007), "Medea in Eleusis, in Princeton,” in Christina Kraus/Simon Goldhill/Helene P. Foley/Jas Elsner (eds.), Visualizing the Tragic. Drama, Myth, and Ritual in Greek Art and Literature. Essays in Honour of Froma Zeitlin, Oxford, 197-217.

Gleba, Margarita/Tatjana Krupa (2012), "Ukraine," in Margarita Gleba/Ulla Mannering (eds.), Textiles and Textile Production in Europe from Prehistory to AD 400, Oxford, 399-425.

Glowacki, Kevin T. (1998), “The Acropolis of Athens before 566 B.C.,” in Kim J. Hartswick/Mary

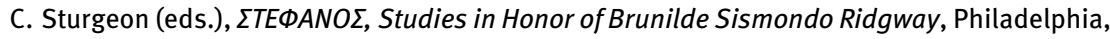
79-88.

Godart, Louis (ed.) (2010), L'Italia e il restauro del Magnifico Cratere. Capolavori del Museo Nazionale di Belgrado, Rome.

Gödde, Susanne (2011), Euphêmia. Die gute Rede in Kult und Literatur der griechischen Antike, Heidelberg.

Goette, Hans Rupprecht (2009), "Images in the Athenian Demosion Sema," in Olga Palagia (ed.), Art in Athens during the Peloponnesian War, Cambridge, 188-206.

Goff, Barbara (2004), Citizen Bacchae: Women's Ritual Practice in Ancient Greece, Berkeley.

Goldberg, Marilyn Y. (1999), "Spacial and Behavioural Negotiation in Classical Athenian City Houses," in Penelope M. Allison (ed.), The Archaeology ofHousehold Activities, London/New York, 142-161.

Goldstein, Michael S. (1978), The Setting of the Ritual Meal in Greek Sanctuaries 600-300 B.C., Berkeley.

Gondek, Renee (2011), “Lifting the Veil: Identity and Dress of Brides on Athenian Vases,” in Lindsey Amundsen-Meyer/Nicole Engel/Sean Pickering (eds.), Identity Crisis: Archaeological Perspectives on Social Identity, Proceedings of the $42^{\text {nd }}$ (2010) Annual Chacmool Conference, University of Calgary, Calgary, Alberta, Calgary, 74-85.

Goode, James M. (2008), Washington Sculpture: A Cultural History of Outdoor Sculpture in the Nation's Capital, Baltimore.

Goossens, R. (1935), “Les Étoliens chaussés d’un seul pied,” RBPh 14, 849-854.

Gorbunova, Kseniia (1983), “Miniatjurnye panafinejskie amfory,” Études et Travaux 13, 111-118.

Gordon, Richard L. (1979). "The Real and the Imaginary: Production and Religion in the Graeco-Roman World," Art History 2, 5-34.

Gorgoni, Carlo/Pallante, Paolo (2000), "On Cycladic Marbles Used in the Greek and Phoenician Colonies of Sicily," in Demetrius U. Schilardi/Dora Katsonopoulou (eds.), Paria Lithos. Parian Quarries, Marble and Workshops of Sculpture, Athens, 497-506.

Gori, Antonio Francesco (1743), Inscriptiones antiquae graecae et romanae, Vol. III, Florence.

Gorst, Isabel (2010), “Turkmenistan to End Personality Cult," Financial Times, January 18.

Govan, Fiona (2008), “Last Statue of Dictator Franco Removed from Mainland Spain," The Telegraph, December 18.

Grabow, Eva (1998), Schlangenbilder in der griechischen schwarzfigurigen Vasenkunst, Munich.

Graef, Botho/Langlotz, Ernst (1925), Die antiken Vasen von der Akropolis zu Athen I: Text und Tafeln, Berlin.

Graham, J. Walter (1974), “Houses of Classical Athens," Phoenix 28, 45-54.

Grassinger, Dagmar (1997), "Jason und Kreusa? Zur Deutung der Szene des Silbercalathus aus WardtLüttingen," in Hans-Hoyer von Prittwitz/Gaffron-Harald Mielsch (eds.), Das Haus lacht vor Silber. Die Prunkplatte von Bizerta und das römische Tafelgeschirr, Cologne, 125-138.

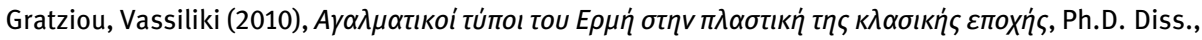
University of loannina.

Graziosi, Barbara/Haubold, Johannes (2010), Homer: Iliad VI, Cambridge.

Greco, Caterina (2009), "Isole nell'isola: Testimonianze e documenti archeologici della provincia di Trapani," in Carmine Ampolo (ed.), Immagine e immagini della Sicilia e di altre isole del Mediterraneo antico, Pisa, 531-549. 
Greco, Giovanna/Pontrandolfo, Angela (1990), Fratte: Un insediamento etrusco-campano, Modena.

Green, J. R. (J. Richard) (1991), “On Seeing and Depicting the Theatre in Classical Athens,” GRBS 32, 15-50.

Green, J. R. (J. Richard) (1994), Theatre in Ancient Greek Society, London/New York.

Green, J. R. (J. Richard) (2006), “Review of Luigi Todisco (ed.), La ceramica figurata a soggetto tragico in Magna Grecia e in Sicilia, Rome 2003,” AJA 110, 516-518.

Green, J. R. (J. Richard)/Eric Handley (1995), Images of the Greek Theatre, London.

Greifenhagen, Adolf (1972), Neue Fragmente des Kleophradesmalers, Heidelberg.

Greifenhagen, Adolf (1977), “Mastoi,” in Ursula Höckmann/Antje Kruge (eds.), Festschrift für Frank Brommer, Mainz, 133-137.

Griffith, Mark (2005), “Satyrs, Citizens and Self-presentation,” in George W. M. Harrison (ed.), Satyr Drama: Tragedy at Play, Swansea, 161-199.

Griffith, R. Drew (1998a), “Corporality in the Ancient Greek Theatre,” Phoenix 52, 230-256.

Griffith, R. Drew (1998b), “The Origin of Memnon,” ClAnt 17, 212-234.

Griffiths, Alan (1989), “Was Kleomenes Mad?,” in Anton Powell (ed.), Classical Sparta: Techniques Behind her Success, Norman, OK, 51-78.

Griffiths, Alan (1999), “Euenius the Negligent Nightwatchman (Herodotus 9.92-6)," in Richard Buxton (ed.), From Myth to Reason? Studies in the Development of Greek Thought, Oxford, 169-182.

Griswold, Charles L. (1998), “The Vietnam Veterans Memorial and the Washington Mall: Philosophical Thoughts on Political Iconography," in Harriet F. Senie/Sally Webster (eds.), Critical Issues in Public Art: Content, Context, and Controversy, Washington, DC, 71-100.

Gruen, Erich (1990), Studies in Greek Culture and Roman Policy, Leiden.

Guinness, Desmond (1982), “A Gabrielli Postscript,” Apollo 115.240 (Feb.), 116.

Gunter, Ann (1990), “Models of the Orient in the Art History of the Orientalizing period," in Heleen Sancisi-Weerdenburg/J. W. (Jan Willem) Drijvers (eds.), The Roots of the European Tradition, Achaemenid History 5, Leiden, 131-147.

Guy, J. Robert (1981), “A Ram’s Head Rhyton Signed by Charinos,” Arts in Virginia 21, 2-15. Habicht, Christian (1982), Studien zur Geschichte Athens in hellenistischer Zeit, Göttingen. Habicht, Christian (1991), "Zu den Münzmagistraten der Silberprägung des Neuen Stils," Chiron 21, $1-23$.

Habicht, Christian (1999), Athens from Alexander to Antony, trans. by Deborah Lucas Schneider, Cambridge, MA.

Habicht, Christian (2006), “Eurykleides III of Kephisia, Victor at the Anakaia,” ZPE 158, 159-163.

Hägg, Robin (1992), “Cult Practice and Archeology: Some Examples From Early Greece,” SIFC10, 79-95.

Halliday, W. R. (William Reginald) (1928), The Greek Questions of Plutarch, Oxford.

Halliwell, Stephen (1987), The Poetics of Aristotle. Translation and Commentary, London.

Halm-Tisserant, Monique (1991), “Autour du mannequin dionysiaque,” Hephaistos 10, 63-88.

Halperin, David M. (2002), How to Do the History of Homosexuality, Chicago.

Halsberghe, G. H. (1984), “Le culte de Deus Sol Invictus à Rome au IIle siècle après J.C.," ANRW II.17.4, 2181-2201.

Hamiaux, Marianne (2001), Les sculptures grecques, I. Des origines à la fin du IVe siècle avant J.-C., $2^{\text {nd }}$ edn., Paris.

Hamilton, Richard (1992), Choes and Anthesteria, Ann Arbor.

Hamilton, Richard (2003), “Lenaia Vases in Context," in Eric Csapo/Margaret C. Miller (eds.), Poetry, Theory, Praxis: The Social Life of Myth, Word and Image in Ancient Greece: Essays in honour of William J. Slater, Oxford, 48-68. 
Hampe, Roland (1960), Ein frühattischer Grabfund, Mainz.

Hanina, Oksana (1970), Antychni bronzy z Pishchanoho, Pishchane.

Hannah, Patricia (2010), “The Warrior Loutrophoroi of Fifth-century Athens," in David M. Pritchard

(ed.), War, Democracy and Culture in Classical Athens, Cambridge, 266-303.

Harding, Phillip (2008), The Story of Athens. The fragments of the local chronicles of Attika, London/ New York.

Harnecker, Joachim (1991), Oltos. Untersuchungen zu Themenwahl und Stil eines frührotfigurigen Schalenmalers, Frankfurt.

Harrison, Evelyn B. (1965), Archaic and Archaistic Sculpture, The Athenian Agora 11, Princeton.

Harrison, Evelyn B. (1985), “Early Classical Sculpture: The Bold Style,” in Cedric G. Boulter (ed.), Greek Art. Archaic into Classical, A Symposium Held at the University of Cincinnati April 2-3, 1982, Leiden, 40-65.

Hart, Mary Louise (1992), Athens and Troy: The Narrative Treatment of the "lliupersis" in Archaic Attic Vase-painting, Ph.D. Diss., University of California, Los Angeles.

Hartwig, Paul (1887), "Rapporto su una serie di tazze attiche e figure rosse con nomi di artisti e di favoriti, raccolta a Roma," MDAI(R) 2,167-170.

Hartwig, Paul (1893), Die Griechischen Meisterschalen der Blüthezeit des strengen rotfigurigen Stiles, Stuttgart/Berlin.

Haspels, C. H. E. (1936), Attic Black-figured Lekythoi, 2 vols., Paris.

Hatzivassiliou, Eleni (2010), Athenian Black Figure Iconography between 510 and 475 B.C., Raden.

Havelock, Christine Mitchell (1981), "Mourners on Greek Vases: Remarks on the Social History of

Women," in Stephen L. Hyatt (ed.), The Greek Vase, Latham, NY, 103-118.

Head, Barclay V. (1911), Historia Numorum. A Manual of Greek Numismatics, $2^{\text {nd }}$ edn., Oxford.

Hedreen, Guy (1992), Silens in Attic Black-figure Vase-painting: Myth and Performance, Ann Arbor.

Hedreen, Guy (1994), "Silens, Nymphs, and Maenads," JHS 114, 47-69.

Hedreen, Guy (1996), "Image, Text, and Story in the Recovery of Helen," ClAnt 15, 152-184.

Hedreen, Guy (2001), Capturing Troy: The Narrative Functions of Landscape in Archaic and Classical Greek Art, Ann Arbor.

Hedreen, Guy (2004), "The Return of Hephaistos, Dionysiac Processional Ritual and the Creation of a Visual Narrative," JHS 124, 38-64.

Hedreen, Guy (2006), “'I let go my force just touching her hair’: Male Sexuality in Athenian Vasepaintings of Silens and lambic Poetry," ClAnt 25, 277-325.

Hedreen, Guy (2009), “Ambivalence, Athenian Dionysiac Vase-imagery, and the Narrative of Human Social Evolution," in Stefan Schmidt/John H. Oakley (eds.), Hermeneutik der Bilder: Beiträge zur Ikonographie und Interpretation griechischer Vasenmalerei, Munich, 125-133.

Hedreen, Guy (2011), "Bild, Mythos, and Ritual. Choral Dance in Theseus's Cretan Adventure on the François Vase," Hesperia 80, 491-510.

Heesen, Pieter (2011), Athenian Little-Master Cups, 2 vols., Amsterdam.

Heftner, Herbert (2003), "Die Vorstellung von Theseus als dem Begründer der Demokratie in Athen des 5. und 4. Jh. v. Chr.," in Alberto Barzanò (ed.), Modelli eroici dall'antichità alla cultura europea, Atti del Convegno Bergamo, 20-22 novembre 2001, Rome, 41-54.

Heiden, Bruce (2008), Homer's Cosmic Fabrication: Choice and Design in the lliad, Oxford. Heiden, Joachim (1998), “Zum frühklassischen Athenatempel von Gela," MDAI(R) 105, 329-340. Heinrich, Frauke (2007), "Bodengelage im Reich des Dionysos. Gelagebilder ohne Klinen in der attischen Bilderwelt des 6. und 5. Jahrhunderts v. Chr.," in Marion Meyer (ed.), Besorgte Mütter und sorglose Zecher. Mythische Exempel in der Bilderwelt Athens, Vienna, 99-153.

Hellmann, Marie-Christine (2010), L'architecture grecque 3. Habitat, urbanisme et fortifications, Paris.

Hemelrijk, Jaap M. (1974), “The Gela Painter in the Allard Pierson Museum,” BABesch 49, 117-158. 
Hemelrijk, Jaap M. (1984), Caeretan Hydriae, 2 vols., Kerameus 5, Mainz.

Hénaff, Marcel (2013), "Ceremonial Gift-Giving: The Lessons of Anthropology from Mauss and Beyond," in Michael L. Satlow (ed.), The Gift in Antiquity, Malden, MA, 12-24.

Henderson, Jeffrey (1974), The Maculate Muse: Obscene Language in Attic Comedy, New Haven/London. Henle, Jane (1973), Greek Myths: A Vase Painter's Notebook, Bloomington.

Herrmann, Hans-Volkmar (1966), Die Kessel der orientalisierenden Zeit I: Kesselattaschen und Reliefuntersätze, Olympische Forschungen 6, Berlin.

Herrmann, Hans-Volkmar (1979), Die Kessel der orientalisierenden Zeit II: Kesselprotomen und Stabdreifüsse, Olympische Forschungen 11, Berlin.

Hesberg, Henner von (1992), Römische Grabbauten, Darmstadt.

Hiebert, Frederik/Cambon, Pierre (2008), Afghanistan. Hidden Treasures from the National Museum, Kabul, Washington, DC.

Higbie, Carolyn (2003), The Lindian Chronicle and the Greek Creation of their Past, Oxford.

Hijmans, Steven (1996), “The Sun Which Did Not Rise in the East: The Cult of Sol Invictus in the Light of Non-Literary Evidence," BABesch 71, 115-150.

Hiller, Heide (2008), “lonische Meister in der Werkstatt des Kraters von Vix? Spurensuche in Anatolien," Araştırma Sonuçları Toplantısı Cilt, 25, 323-338.

Hirayama, Toko (2010), Kleitias and Attic Black-figure Vases in the Sixth-century B.C., Tokyo.

Hoepfner, Wolfram (ed.) (1999), Geschichte des Wohnens 1: 5000 v. Chr.-500 n. Chr., Stuttgart, 239-243.

Hoepfner, Wolfram/Schwandner, Ernst Ludwig (1994), Haus und Stadt im klassischen Griechenland, Wohnen in der klassischen Polis $1,2^{\text {nd }}$ edn., Munich.

Hölbl, Günther (1978), Zeugnisse Ägyptischer Religionsvorstellungen für Ephesus, Leiden.

Hölscher, Tonio (1988), "Historische Relief," in Mathias R. Hofter (ed.), Kaiser Augustus und die verlorene Republik, Eine Ausstellung im Martin-Gropius-Bau, Berlin, 7. Juni-14. August 1988, Mainz, 351-400.

Hölscher, Tonio (2003), “Images of War in Greece and Rome: Between Military Practice, Public Memory, and Cultural Symbolism," JRS 93, 1-17.

Hoffelner, Klaus (1988), “Die Metopen des Athener-Schatzhauses. Ein neuer Rekonstruktionsversuch," $\operatorname{MDAI}(A)$ 103, 77-117.

Hoffmann, Herbert (1980), “Knotenpunkte: Zur Bedeutungsstruktur griechischer Vasenbilder," Hephaistos 2, 127-154.

Hofstetter, Eva (1990), Sirenen im archaischen und klassischen Griechenland, Würzburg.

Holst-Warhaft, Gail (1992), Dangerous Voices: Women's Laments and Greek Literature, London/ New York.

Holtzmann, Bernard (2003), L'acropole d'Athènes: Monuments, cultes et histoire du sanctuaire d'Athèna Polias, Paris.

Hornbostel, Wilhelm (1980), Aus Gräbern und Heiligtümern: Die Antikensammlung Walter Kropatscheck, Mainz.

Horsfall, Nicholas (1985), “CIL VI 37965 = CLE 1988 (Epitaph of Allia Potestas): A Commentary,” ZPE 61, 251-272.

Hosoi, Noémie (2012), "Vases en ronde: Ornements figuratifs et objets décoratifs dans la céramique attique du Ve siècle av. J.-C," Métis 10, 175-200.

Hoyt-Grimes, Cynthia (1986), “A Kylix and Fragments by the Boread Painter," Greek Vases in the J. Paul Getty Museum 3, Occasional Papers on Antiquities 2, Malibu, 29-34.

Hubbard, Thomas K. (1998), “Popular Perceptions of Elite Homosexuality in Classical Athens," Arion 6, 48-78.

Hubbard, Thomas K. (ed.) (2003), Homosexuality in Greece and Rome. A Sourcebook of Basic Documents, Berkeley. 
Humphreys, S. C. (Sarah C.) (1993), The Family, Women and Death: Comparative Studies, $2^{\text {nd }}$ edn., Ann Arbor.

Hurwit, Jeffrey M. (1977), “Image and Frame in Greek Art," AJA 81, 1-30.

Hurwit, Jeffrey M. (1989), “The Kritios Boy: Discovery, Reconstruction, and Date," AJA 93, 41-80.

Hurwit, Jeffrey M. (1991), "The Representation of Nature in Early Greek Art," in Diana Buitron-Oliver

(ed.), New Perspectives in Early Greek Art, Washington, DC, 33-62.

Hurwit, Jeffrey M. (1995), “The Doryphoros: Looking Backward,” in Warren G. Moon (ed.), Polykleitos, the Doryphoros, and Tradition, Madison, 3-18.

Hurwit, Jeffrey M. (1999), The Athenian Acropolis. History, Mythology, and Archaeology from the Neolithic Era to the Present, Cambridge.

Hurwit, Jeffrey M. (2004), The Acropolis in the Age of Pericles, Cambridge.

Huskinson, Janet (1996), Roman Children's Sarcophagi. Their Decoration and its Social Significance, Oxford.

Immerwahr, Henry R. (1946), “Choes and Chytroi,” TAPhA 77, 245-260.

Immerwahr, Henry R. (1984), "The signatures of Pamphaios," AJA 88, 341-352.

Immerwahr, Henry R. (1990), Attic Script. A Survey, Oxford.

Immerwahr, Henry R. (1992), "New Wine in Ancient Wineskins. The Evidence from Attic Vases,"

Hesperia $61,121-132$.

Immerwahr, Sara A. (1971), The Neolithic and Bronze Ages, The Athenian Agora 14, Princeton.

Intzesiloglou, Babis G. (2002), "The Archaic Temple of Apollo at Ancient Metropolis (Thessaly)," in

Maria Stamatopoulou/Marina Yeroulanou (eds.), Excavating Classical Culture: Recent Archaeological Discoveries in Greece, Oxford, 109-115.

Iozzo, Mario (2006), "Osservazioni sulle più antiche importazioni di ceramica greca a Chiusi e nel suo territorio (circa 650/620-550/520 a.C.)," in Juliette de la Genière (ed.), Les clients de la céramique grecque, Cahiers du CVA, France 1, Paris, 107-140.

Iozzo, Mario (2012), “Chiusi, Telemaco e il Pittore di Penelope,” in Stefan Schmidt/Adrian Stähli (eds.), Vasenbilder im Kulturtransfer. Zirkulation und Rezeption griechischer Keramik in Mittelmeerraum, Munich, 69-83.

Iozzo, Mario (2013), “The François Vase: Notes on Technical aspects and Function,” in H. A. (H. Alan) Shapiro/Mario lozzo/Adrienne Lezzi-Hafter (eds.), The François Vase. New Perspectives, Papers of the International Symposium, Villa Spelman, Florence, 23-24 May 2003, 2 vols., Kilchberg/ Zurich, 53-65.

Iozzo, Mario (2014), “Plates by Paseas," in John H. Oakley (ed.), Athenian Potters and Painters III, The Conference Proceedings, Oxford, 81-97.

Iozzo, Mario (ed.) (2009), The Chimaera of Arezzo, Florence.

Isler-Kerényi, Cornelia (2001), Dionysos nella Grecia arcaica. Il contributo delle immagini, Pisa.

Isler-Kerényi, Cornelia (2004), Civilizing Violence. Satyrs on $6^{\text {th }}$-century Greek Vases, Orbis Biblicus et Orientalis 208, Fribourg.

Isserlin, Benedikt S. J./du Plat Taylor, Joan (1974), Motya. A Phoenician and Carthaginian City in Sicily I: Field Work and Excavation, Leiden.

Jacobsthal, Paul (1931), Die melischen Reliefs, Berlin.

Jahn, Otto (1858), “Il ratto de Palladio," Annali dell'Instituto di Corrispondenza Archeologica 30, 228-264.

Jaillard, Dominique (2007), Configurations d'Hermès. Une "théogonie hermaïque," Liège.

Jameson, Michael H. (1990), "Domestic Space in the Greek City-State," in Susan Kent (ed.), Domestic Architecture and the Use of Space. An Interdisciplinary Cross-Cultural Study, Cambridge, 92-113.

Jameson, Michael H. (1993), “The Asexuality of Dionysus," in Thomas H. Carpenter/Christopher Faraone (eds.), Masks of Dionysus, Ithaca, NY, 44-64. 
Janko, Richard (1986), "The Shield of Heracles and the Legend of Cycnus," CQ 36, 38-59.

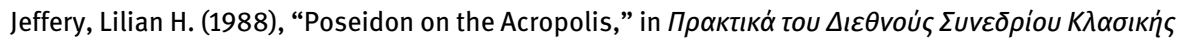

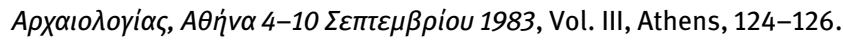

Jeffery, Lillian H. (1961), The Local Scripts of Archaic Greece: A Study of the Origin of the Greek

Alphabet and its Development from the Eighth to the Fifth Centuries B.C., Oxford.

Jehasse, Jean/Jehasse, Laurence (1973), La nécropole préromaine d'Aléria (1960-1968), Paris.

Jenkins, Ian (1985), “The Ambiguity of Greek Textiles,” Arethusa 18, 109-132.

Jenkins, Ian (1994), The Parthenon Frieze, London.

Johnson, Helen M. (1919), “The Portrayal of the Dog on Greek Vases," Classical Weekly 12, 209-213.

Johnson, Hugh (1990), Hugh Johnsons Weingeschichte: Von Dionysos bis Rothschild, Stuttgart.

Johnston, Alan W. (1979), Trademarks on Greek Vases, Warminster.

Johnston, Alan W. (2006), Trademarks on Greek Vases: Addenda, Warminster.

Johnston, Richard W./Mulroy, David (2009), "The Hymn to Hermes and the Athenian Altar of the Twelve Gods," CW103, 3-16.

Johnston, Sarah Iles (1999), Restless Dead: Encounters Between the Living and the Dead in Ancient Greece, Berkeley.

Johnston, Sarah Iles (2002), “Myth, Festival, and Poet: The Homeric Hymn to Hermes and its Performative Context," CPh 97, 109-132.

Jones, John Ellis (1975), “Town and Country Houses of Attica in Classical Times,” in H. F. Mussche/ Paule Spitaels/F. Goemaere-De Poerck (eds.), Thorikos and the Laurion in Archaic and Classical Times, Papers and Contributions of the Colloquium held in March, 1973, at the State University of Ghent, Miscellanea Graeca I, Ghent, 63-140.

Jones, Polly (2006), “'Idols in Stone,' or Empty Pedestals? Debating Revolutionary Iconoclasm in the Post-Soviet Transition," in Stacy Boldrick/Richard S. Clay (eds.), Iconoclasm: Contested Objects, Contested Terms, London, 241-260.

Jones, W. H. S. (1964), Pausanias: Description of Greece, Cambridge, MA.

Jouan, François/Van Looy, Herman (2003), Euripide, Tragédies. Vol. VIII.4: Fragments, Paris.

Jucker, Hans (1977), “Herakles und Atlas auf einer Schale des Nearchos in Bern,” in Ursula Höckmann/ Antje Krug (eds.), Festschrift für Frank Brommer, Mainz, 191-199.

Junker, Klaus (2012), Interpreting the Images of Greek Myths: An Introduction, trans. by Annemarie Künz-Snodgrass/Anthony Snodgrass, Cambridge.

Jüthner, Julius (1968), Die athletischen Leibesübungen der Griechen, Wien.

Kader, Ingebor/Koch-Brinkmann Ulrike (eds.) (2006), Penelope rekonstruiert. Geschichte und Deutung einer Frauenfigur, Sonderausstellung des Museums für Abgüsse Klassischer Bildwerke München 9. Oktober bis 15. Januar 2007, Munich.

Kaeser, Berthold (2006), “Ein Mensch erringt eine Göttin: Peleus und Thetis, die Eltern Achills," in Raimund Wünsche (ed.), Mythos Troja, Ausstellungskatalog Staatliche Antikensammlungen und Glyptothek München, Munich, 87-100.

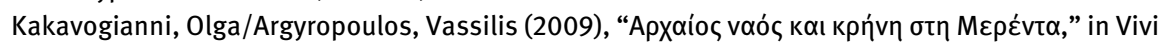
Vassilopoulou/Stella Katsarou-Tseveleki (eds.), From Mesogeia to Argosaronikos: Second Ephorate of Prehistoric and Classical Antiquities, Research of a Decade 1993-2003, Proceedings of Conference, Athens, December 18-20, 2003, Markopoulo, 177-188.

Kaltsas, Nikolaos (2002), Sculpture in the National Archaeological Museum, Athens, Los Angeles. Kaltsas, Nikolaos/H. A. (H. Alan) Shapiro (eds.) (2008), Worshiping Women: Ritual and Reality in Classical Athens, New York.

Kampen, Natalie (1981), Image and Status: Roman Working Women in Ostia, Berlin.

Kanowski, M. G. (Maxwell G.) (1984), Containers of Classical Greece: A Handbook of Shapes, St. Lucia, Queensland/New York/Lawrence, MA. 
Karageorghis, Vassos/Markoe, Glenn (1996), “A Phoenician Bronze Bowl Fragment in the Ligabue Collection, Venice," in Enrico Acquaro (ed.), Alle soglie della classicità. Il Mediterraneo tra tradizione e innovazione. Studi in onore di Sabatino Moscati, Pisa, 823-831.

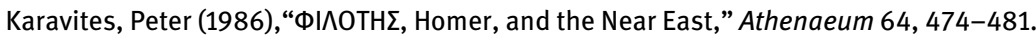

Karavites, Peter (1987), "Diplomatic Envoys in the Homeric world," RIDA 34, 41-100.

Karo, Georg (1931), "Bericht über die archäologische Funde vom Sommer 1930 bis Juni 1931 im Griechenland und Dodekanes," $A A, 211-308$.

Karoglou, Kyriaki (2010), Attic Pinakes. Votive Images in Clay, Oxford.

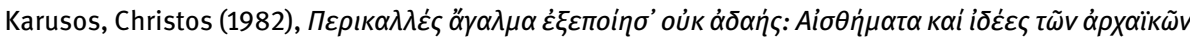

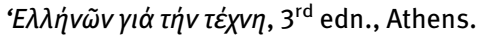

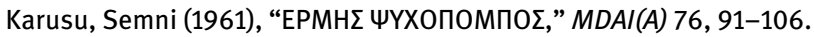

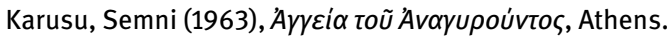

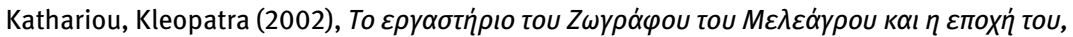

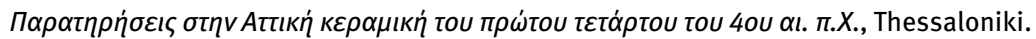

Kauffmann-Samaras, Aliki (1987), “Le 'Peintre C,' peintre novateur de la céramique attique, dans la collection du Louvre," RLouvre 5/6, 340-355.

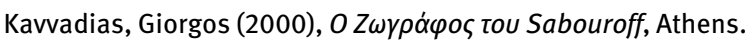

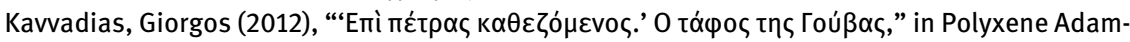

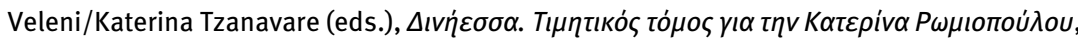
Thessaloniki, 255-267.

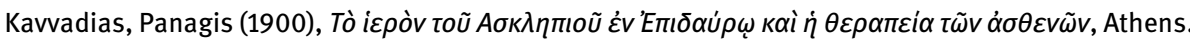

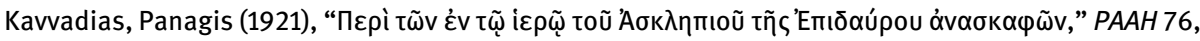
39-41.

Keller, Otto (1909), Die antike Tierwelt I, Leipzig.

Kent, J. P. C. (John Philip Cozens) (1978), Roman Coins, London.

Kenyon, Frederick (1893), Greek Papyri in the British Museum. Catalogue with Texts: I, London.

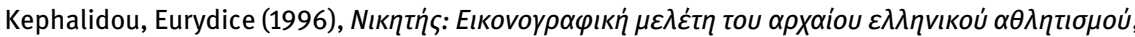
Thessaloniki.

Kephalidou, Eurydice (2010), “Dead Men Face Down: Homer, Art and Archaeology,” in Elena Walter-

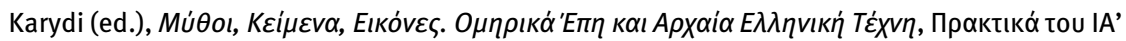

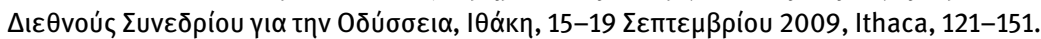

Keuls, Eva (1985), The Reign of the Phallus. Sexual Politics in Ancient Athens, Berkeley/Los Angeles. Keyt, David (1993), “Aristotle and Anarchism," Reason Papers 18, 133-152.

Khodza, Elena (2013), “Terracotta Figure of a Youth from Pyotr A. Sabouroff's Collection," Reports of the State Hermitage Museum 70, 95-106.

Kilian-Dirlmeier, Imma (1985), “Fremde Weihungen in griechischen Heiligtümern von 8. bis Beginn des 7. Jahrhunderts v. Chr.," JRGZ 32, 215-254.

Kilinski, Karl (2002), The Flight of Icarus Through Western Art, Lewiston, NY.

Kilmer, Martin L. (1993), Greek Erotica on Attic Red-figure Vases, London.

Kilmer, Martin L. (1997), "Painters and Pederasts: Ancient Art, Sexuality, and Social History," in Mark Golden/Peter Toohey (eds.), Inventing Ancient Culture: Historicism, Periodization and the Ancient World, London/New York, 36-49.

Kirk, G. S. (Geoffrey S.) (1990), The lliad: A Commentary, Vol. 2: Books 5-8, Cambridge.

Kitchell, Kenneth F., Jr. (2004), “Man's Best Friend? The Changing Role of the Dog in Greek Society,” in Barbro Santillo Frizell (ed.), PECUS. Man and Animal in Antiquity, Proceedings of the Conference at the Swedish Institute in Rome (Sept. 9-12, 2002), Rome, 177-182.

Kleiner, Diana (1992), Roman Sculpture, New Haven.

Kluiver, Jeroen (1995), “Early ‘Tyrrhenian’: Prometheus Painter, Timiades Painter, Goltyr Painter,” BABesch 70, 55-103. 
Kluiver, Jeroen (1996), “The Five Later 'Tyrrhenian' Painters,” BABesch 71, 1-58.

Kluiver, Jeroen (2003), The Tyrrhenian Group of Black-Figure Vases: From the Athenian Kerameikos to the Tombs of South Etruria, Amsterdam.

Knaus, Florian (2006), “Keine Heldentat. Achill - ein Kindermörder,” in Raimund Wünsche (ed.), Mythos Troja, Ausstellungskatalog Staatliche Antikensammlungen und Glyptothek München, Munich, 162-171.

Knell, Heiner (1998), Mythos und Polis. Bildprogramme griechischer Bauskulptur, Darmstadt.

Knigge, Ursula (1983), “Ein Jünglingskopf vom Heiligen Tor in Athen,” MDAI(A) 98, 45-56.

Knittlmayer, Brigitte (1997), Die attische Aristokratie und ihre Helden: Untersuchungen zu Darstellungen des trojanischen Sagenkreises im 6. und frühen 5. Jahrhundert v. Chr., Heidelberg.

Knudsen, Sandra E./Craine, Clifford/Tykot, Robert H. (2002), “Analysis of Classical Marble Sculptures in the Toledo Museum of Art,” in John J. Herrmann Jr./Norman Herz/Richard Newman (eds.), Interdisciplinary Studies on Ancient Stone, Asmosia 5, London, 231-239.

Koch-Harnack, Gundel (1983), Knabenliebe und Tiergeschenke. Ihre Bedeutung im päderastischen Erziehungssystem Athens, Berlin.

Koch, Guntram/Sichtermann, Hellmut (1982), Römische Sarkophage. Handbuch der Archäologie 3, Munich.

Köhler, Ulrich (1884), “Eine Illustration zu Theognis,” MDAI(A) 9, 1-4.

Kokkinou, Angeliki (2011), Poseidon in Attica: Cults and Iconography (ca. 510-300 B.C.E.), Ph.D. Diss., The Johns Hopkins University.

Koortbojian, Michael (1995), Myth, Meaning, and Memory on Roman Sarcophagi, Berkeley.

Koortbojian, Michael (1996), “Review of Vassiliki Gaggadis-Robin, Jason et Médée sur les sarcophages d'époque imperial, Rome and Paris 1994," AJA 100, 435-436.

Koortbojian, Michael (2006), “The Freedman's Voice: The Funerary Monument of Aurelius Hermia and Aurelia Philematio," in Eve D’Ambra/Guy Métraux (eds.), The Art of Citizens, Soldiers, and Freedmen in the Roman World, BAR International Series 1526, Oxford, 91-99.

Korres, Manolis (1997), “Der Athena-Tempel auf der Akropolis,” in Wolfram Hoepfner (ed.), Kult und Kultbauten auf der Akropolis, Internationales Symposion vom 7. bis 9. Juli 1995 in Berlin, Berlin, 218-243.

Korzus, Bernard (1984), Griechische Vasen aus westfälischen Sammlungen, Münster.

Kosmetatou, Elizabeth (1993), “Horse Sacrifices in Greece and Cyprus,” JPR 7, 31-41.

Kossatz-Deissman, Anneliese (1978), Dramen des Aischylos auf Westgriechischen Vasen, Mainz.

Kovacs, David (trans.) (1994), Euripides. Cyclops. Alcestis. Medea. Cambridge, MA.

Krämer, Edith (2001), Hermen bärtiger Götter. Klassische Vorbilder und Formen der Rezeption, Münster.

Krause, Clemens (1977), “Grundformen des griechischen Pastashauses,” AA, 164-179.

Krauskopf, Ingrid (1995), Heroen, Götter und Dämonen auf etruskischen Skarabäen, Mannheim.

Kreikenbom, Dietmar (1992), Griechische und römische Kolossalporträts bis zum späten ersten Jahrhundert nach Christus, Berlin.

Kretschmer, Paul (1894), Die griechischen Vaseninschriften, Gütersloh.

Kreuzer, Bettina (1992), Frühe Zeichner 1500-500 vor Chr. Ägyptische, griechische und etruskische Vasenfragmente der Sammlung H. A. Cahn, Basel, Waldkirch.

Kreuzer, Bettina (1998), Die attisch schwarzfigurige Keramik aus dem Heraion von Samos, Samos 22, Bonn.

Kreuzer, Bettina (2011), Griechische, ptolemäische und römische Keramik in Roemer- und PelizaeusMuseum Hildesheim (mit Beiträgen von Martin Dennert), Hildesheim.

Krieger, Xenia (1975), Der Kampf zwischen Peleus und Thetis in der griechischen Vasenmalerei. Eine typologische Untersuchung, Münster. 
Kroll, John H. (1982), "The Ancient Image of Athena Polias," in Studies in Athenian Architecture,

Sculpture and Topography: Presented to Homer A. Thompson, Hesperia Supplement 20, Princeton, 65-76.

Kroll, Wilhelm (1914), "Die Grabschrift der Allia Potestas," Philologus 73, 274-288.

Kroll, Wilhelm (1936), “Unum exuta pedem - ein volkskundlicher Seitensprung," Glotta 25, 152-158.

Krumeich, Ralph/Pechstein, Nikolaus/Seidensticker, Bernd (1999), Das griechische Satyrspiel, Darmstadt.

Kryžickij [Kryzhistky], Sergej Dmitrievič et al. (1989), Sel'skaia okruga Ol'vii, Kiev.

Kübler, Karl (1954), Die Nekropole des 10. bis 8. Jahrhunderts, Kerameikos V.1, Berlin.

Kübler, Karl (1970), Die Nekropole des späten 8. bis frühen 6. Jahrhunderts, Kerameikos VII.2, Berlin.

Kullmann, Wolfgang (2005), “Man as a Political Animal in Aristotle," in David Keyt/Fred Miller (eds.), A Companion to Aristotle's Politics, Oxford, 94-117.

Kunisch, Norbert (1997), Makron, Mainz.

Kunze-Götte, Erika (2000), Archaische Keramik aus Olympia: Lakonische und lakonisierende Keramik, Olympische Forschungen 28, Berlin.

Kunze-Götte, Erika (2006), Myrte als Attribut und Ornament aufattischen Vasen, Akanthiskos 1, Kilchberg/Zurich.

Kunze, Christian (2005), “Dialog statt Gewalt. Neue Erzählperspektiven in der frühklassischen Vasenmalerei," in Günther Fischer/Susanne Moraw (eds.), Die andere Seite der Klassik. Gewalt im 5. und 4. Jahrhundert v. Chr., Kulturwissenschaftliches Kolloquium Bonn, Kunst- und Ausstellungshalle der Bundesrepublik Deutschland, 11.-13. Juli 2002, Stuttgart, 45-71.

Kurke, Leslie (1997), “Inventing the Hetaira: Sex, Politcs, and Discursive Conflict in Archaic Greece,” ClAnt 16, 106-150.

Kurtz, Donna C./Boardman, John (1971), Greek Burial Customs, Ithaca, NY.

Kurtz, Donna C./Boardman, John (1986), "Booners," Greek Vases in the J. Paul Getty Museum 3, Occasional Papers on Antiquities 2, Malibu, 35-70.

Kuttner, Ann L. (1995), Dynasty and Empire in the Age of Augustus: The Case of the Boscoreale Cups, Berkeley.

Kyle, Donald G. (1987), Athletics in Ancient Athens, Leiden.

La Rocca, Eugenio (1985), “Il giovane di Mozia come auriga. Un testimonio a favore,” PP 40, 452-463. Lacey, Walter K. (1964), “Thucydides, II,45,2,” PCPS 10, 47-49.

Lacroix, Léon (1992), “Thesée et Aithra sur la coup de Macron, II,” in Serta Leodiensia secunda. Mélanges publiés par la Classique de Liège à l'occasion du $175^{\circ}$ anniversaire de l'Université, Liège, 247-256.

Lahusen, Götz (1994), Catalogue Entry in Peter C. Bol (ed.), Forschungen zur Villa Albani. Katalog der antiken Bildwerke IV, Berlin, 416 no. 525.

Lambert, Stephen (2002), "The Sacrificial Calendar of Athens," ABSA 97, 353-399.

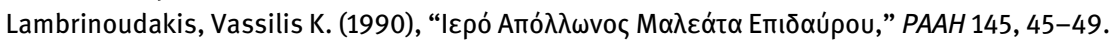

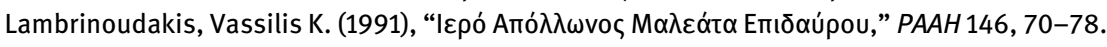

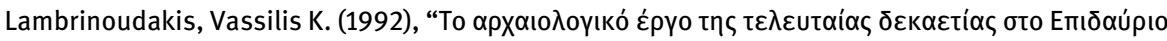

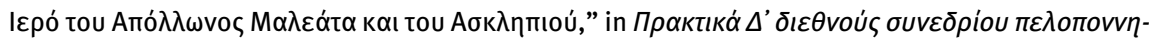

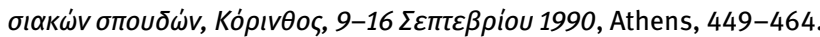

Lambrinoudakis, Vassilis K. (1994a), “L’eau médicale à Épidaure,” in René Ginouvès et al. (eds.), L'eau, la santé et la maladie dans le monde grec, Actes du colloque organisé à Paris (CNRS et Fondation Singer-Polignac) du 25-27 novembre 1992, BCH Supplement 28, Paris, 225-236.

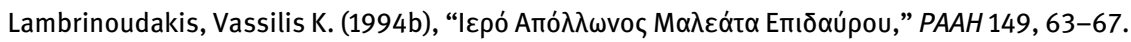

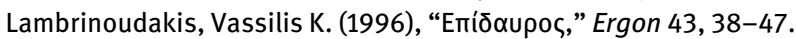

Lambrinoudakis, Vassilis K. (2002), “Conservation and Research: New Evidence on a Long-Living Cult. The Sanctuary of Apollo Maleatas and Asklepios at Epidauros," in Maria Stamatopoulou/Marina 
Yeroulanou (eds.), Excavating Classical Culture. Recent Archaeological Discoveries in Greece, BAR International Series 1031, Oxford, 212-224.

Lampis, Nicoletta (2007), "La dea a mortale: Il mito di Circe nella ceramic attica," in Simonetta

Angiolillo/Marco Giuman (eds.), Imago: Studi di iconografia antica, Cagliari, 111-138.

Langner, Martin (forthcoming), Meisterwerk und Massenware. Dekor und Funktion spätrotfiguriger Bildervasen aus Athen, Berlin.

Lapatin, Kenneth (ed.) (2008), Papers on Special Techniques in Athenian Vases, Proceedings of a

Symposium held in Connection with the Exhibition, Los Angeles.

Larson, Jennifer (2001), Greek Nymphs: Myth, Cult, Lore, Oxford.

Latacz, Joachim et al. (2008), Homer: Der Mythos von Troia in Dichtung und Kunst, Exhibition

Catalogue, Antikenmuseum Basel und Sammlung Ludwig, Munich.

Lattimore, Richmond (trans.) (1951), The lliad of Homer, London.

Laughy, Michael (2010), Ritual and Authority in Early Athens, Ph.D. Diss., University of California,

Berkeley.

Laurin, Joseph R. (2005), Homosexuality in Ancient Athens, Victoria.

Lauter, Hans (1986), Die Architektur des Hellenismus, Darmstadt.

Lauter-Bufe, Heide/Lauter, Hans (1971), "Wohnhäuser und Stadtviertel des klassischen Athen,"

$\operatorname{MDAI}(A)$ 86, 109-124.

Lawall, Mark L. et al. (2002), “Notes from the Tins. 2: Research in the Stoa of Attalos," Hesperia 71, 415-433.

Lawrence, Arnold W. (1983), Greek Architecture, $4^{\text {th }}$ edn., New Haven.

Lazzarini, Lorenzo/Basile, Beatrice (2012), "The Archaeometric Identification of the Marble of the Greek

Statuary and Architectural Elements of the P. Orsi Museum in Syracuse," Marmora 8,11-32.

Lear, Andrew/Cantarella, Eva (2008), Images of Ancient Greek Pederasty. Boys were their Gods, London/New York.

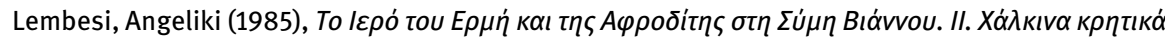
тореи́ $\mu \alpha \tau \alpha$, Athens.

Lemos, Anna A. (2009), "Iconographical Divergencies in Late Athenian Black-Figure: The Judgment of Paris," in John H. Oakley/Olga Palagia (eds.), Athenian Potters and Painters II, The Conference Proceedings, Oxford/Oakville, 134-146.

Lesky, Albin (1972), Die tragische Dichtung der Hellenen, $3^{\text {rd }}$ edn., Göttingen.

Levine, Rachel J. (2008), Dreaming the Divine: Ritual and Architecture at Ancient Greek Healing Sanctuaries of Asklepios, Ph.D. Diss., University of Toronto.

Lewis, Sian (2002), The Athenian Woman: An Iconographic Handbook, London/New York. Leypold, Christina (2008), Bankettgebäude in griechischen Heiligtümern, Wiesbaden.

Lezzi-Hafter, Adrienne (1983), "Mänadengelage und Götterliebe in Malibu: Zu einem Komplex attischer rotfiguriger Fragmente aus Etrurien im J. Paul Getty Museum," Greek Vases in the J. Paul Getty Museum 1, Malibu, 85-114.

Lezzi-Hafter, Adrienne (1988), “Anthesterien und Hieros Gamos. Ein Choenbild des Methyse-Malers,” in Jette Christiansen/Torben Melander (eds.), Proceedings of the $3^{\text {rd }}$ Symposium on Ancient Greek and Related Pottery, Copenhagen, 325-334.

Lezzi-Hafter, Adrienne (2012), “The Xenophantos Chous from Kerch with Cypriot Themes," in Stine Schierup/Bodil Bundgaard Rasmussen (eds.), Red-figure Pottery in its Ancient Setting, Acts of the International Colloquium held at the National Museum of Denmark in Copenhagen, November 5-6, 2009, Gösta Enbom Monographs 2, Aarhus, 33-42.

Lindner, Ruth (1984), Der Raub der Persephone in der antiken Kunst, Würzburg.

Lindner, Ruth (2006), "Mütter und Söhne in der Bildkunst Griechenlands. Klassischen Athen und hellenistisches Pergamon," in Silvia Schroer (ed.), Images and Gender. Contributions to the Hermeneutics of Reading Ancient Art, Fribourg, 331-350. 
Linfert, Andreas (1990), “Die Schule des Polyklet Kat. 103-153,” in Herbert Beck/Peter C. Bol/Maraike Bückling (eds.), Polyklet. Der Bildhauer der griechischen Klassik, Ausstellung im Liebieghaus Museum alter Plastik, Frankfurt, Mainz.

Lissarrague, François (1988), “La stèle avant la lettre,” AION(archeol) 10, 97-105.

Lissarrague, François (1990a), The Aesthetics of the Greek Banquet. Images of Wine and Ritual, trans. by Andrew Szegedy-Maszak, Princeton.

Lissarrague, François (1990b), “Around the Krater. An Aspect of Banquet Imagery,” in Oswyn Murray (ed.), Sympotica. A Symposium on the Symposion, Oxford, 196-209.

Lissarrague, François (1990c), "Sexual Life of Satyrs," in David M. Halperin/John J. Winkler/Froma I. Zeitlin (eds.), Before Sexuality: The Construction of Erotic Experience in the Ancient Greek World, Princeton, 53-81.

Lissarrague, François (1990d), "Why Satyrs are Good to Represent," in John J. Winkler/Froma I. Zeitlin (eds.), Nothing to do with Dionysos? Athenian Drama in its Social Context, Princeton, 228-236.

Lissarrague, François (1993), “On the Wildness of Satyrs," in Thomas H. Carpenter/Christopher Faraone (eds.), Masks of Dionysus, Ithaca, NY, 207-220.

Lissarrague, François (1998), "Satyres chez les femmes," in Paul Veyne/François Lissarrague/Françoise Frontisi-Ducroux (eds.), Les Mystères du Gynécée, Paris, 179-198.

Lissarrague, François (1999), Vases grecs: Les Athéniens et leurs images, Paris.

Lissarrague, François (2000), “A Sun-Struck Satyr in Malibu,” in Gocha R. Tsetskhladze/A. J. N. W. Prag/Anthony Snodgrass (eds.), Periplous: Papers on Classical Art and Archaeology Presented to Sir John Boardman, London/New York, 190-197.

Lissarrague, François (2001), Greek Vases: The Athenians and their Images, trans. by Kim Allen, New York.

Lissarrague, François (2010), "Transmission and Memory: The Arms of the Heroes," in

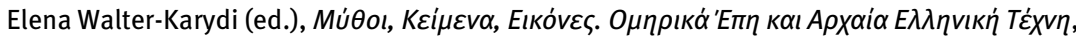

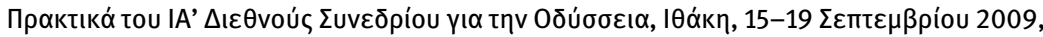
Ithaca, 191-207.

Lissarrague, François (2013), La cité des satyres: Une anthropologie ludique (Athènes Vle-Ve siècle avant J.-C.), Paris.

Lopes, Dominic M. M. (1997), “Art Media and the Sense Modalities: Tactile Pictures," Philosophical Quarterly 47.189, 425-440.

Loraux, Nicole (1990), “Herakles: The Super-male and the Feminine," in David M. Halperin/John J. Winkler/Froma I. Zeitlin (eds.), Before Sexuality: The Construction of Erotic Experience in the Ancient Greek World, Princeton, 21-52.

Lord, Carnes (1991), “Aristotle's Anthropology,” in Carnes Lord/David O'Connor (eds.), Essays on the Foundations of Aristotelian Political Science, Berkeley/Los Angeles/Oxford, 49-73.

Lorenz, Susanne (2006), “Rettungen,” in Raimund Wünsche (ed.), Mythos Troja, Ausstellungskatalog Staatliche Antikensammlungen und Glyptothek München, Munich, 326-341.

Louden, Bruce (2006), The lliad: Structure, Myth, and Meaning, Baltimore.

Lovejoy, Arthur O./Boas, George (1935), Primitivism and Related Ideas in Antiquity. A Documentary History of Primitivism and Related Ideas, Vol. 1, Baltimore.

Low, Polly (2010), "Commemoration of the War Dead in Classical Athens: Remembering Defeat and Victory," in David Pritchard (ed.), War, Democracy and Culture in Classical Athens, Cambridge, 341-358.

Lowenstam, Steven (1992), “The Uses of Vase-Depictions in Homeric Studies,” TAPhA 122, 165-198. Lowenstam, Steven (1997), "Talking Vases: The Relationship between the Homeric Poems and Archaic Representations of Epic Myth," TAPhA 127, 21-76.

Lowenstam, Steven (2008), As Witnessed by Images: The Trojan War Tradition in Greek and Etruscan Art, Baltimore. 
Lowenthal, Constance (1989), “Art Crime Update. Greek Cup and Other Treasures Lost, Found,” The Wall Street Journal, 31 October, A18.

Luce, Jan-Marc (1998), “Thésée, le synœcisme et l'agora d'Athènes,” RA 1, 3-31.

Luce, Jan-Marc (2005), “Erechthée, Thésée, les Tyrannoctones et les espaces publics athéniens," in Emanuele Greco (ed.), Teseo e Romolo. Le origini di Atene e Roma a confronto, Atti del Convegno Internazionale di Studi: Scuola Archeologica Italiana di Atene, Atene, 30 giugno-1 luglio 2003, Athens, 143-164.

Lullies, Reinhard (1931), Die Typen der griechischen Herme, Königsberg.

Lunsingh Scheurleer, Robert (1984), "A Note on Two Casts in the Allard Pierson Museum Amsterdam," in Nicola Bonacasa/Antonino Di Vita (eds.), Alessandria e il mondo ellenistico-romano. Studi in onore di Achille Adriani, Vol. 2, Rome, 359-362.

Lusnia, Susann S. (2006), "Battle Imagery and Politics on the Severan Arch in the Roman Forum," in Sheila Dillon/Katherine Welch (eds.), Representations of War in Ancient Rome, Cambridge, 272-299.

Lynch, Kathleen M. (2007), "More Thoughts on the Space of the Symposium," in Ruth Westgate/Nick Fisher/James Whitley (eds.), Building Communities. House, Settlement and Society in the Aegean and Beyond, Proceedings of a Conference held at Cardiff University, 17-21 April 2001, London, 243-249.

Lynch, Kathleen M. (2011), The Symposium in Context. Pottery from a Late Archaic House Near the Athenian Agora, Hesperia Supplement 46, Princeton.

Lynch, Kathleen M. (2012), "Winemaking Scenes on Attic Red-Figured Cups. Not Crushing but Pigeage, Punching Down the Cap," BABesch 87, 151-157.

Lyons, Claire L./Bennett, Michael/Marconi, Clemente (eds.) (2013), Sicily: Art and Invention between Greece and Rome, Malibu.

Lyons, Deborah (1997), Gender and Immortality: Heroines in Ancient Greek Myth and Cult, Princeton.

Lyons, Deborah (2012), Dangerous Gifts: Gender and Exchange in Ancient Greece, Austin.

Ma, John (2008), “Chaironeia 338: Topographies of Commemoration,” JHS 128, 72-91.

Maass, Ernst (1883), Analecta Eratosthenica, Berlin.

Maass, Ernst (1921), “Die Erigone des Sophokles,” Philologus 77, 1-25.

Maass, Michael (1972), Die Prohedrie des Dionysostheaters in Athen, Vestigia 15, Munich.

Maass, Michael (1978), Die geometrischen Dreifüsse von Olympia, Olympische Forschungen 10, Berlin.

Mackay, E. Anne (2010), Tradition and Originality: A Study of Exekias, BAR International Series 2092, Oxford.

MacMullen, Ramsay (1980), “Women in Public in the Roman Empire," Historia 29, 208-218.

Maddoli, Gianfranco (1980), “Filottete in Italia," in L'epos greco in occidente, Atti del XIX Convegno di Studi sulla Magna Grecia (Taranto 7-12 ottobre 1979), Taranto, 133-167.

Madigan, Brian C. (2008), Corinthian and Attic Vases in the Detroit Institute of Arts: Geometric, Blackfigure and Red-figure, Leiden.

Maffre, Jean-Jacques (1985), “Le combat d'Héracles contre l'hydre de Lerne dans la collection de vases grecs du Louvre," RLouvre 35, 83-95.

Maffre, Jean-Jacques (1999), “Le Peintre du Louvre G 265," in Marie-Christine Villaneuva Puig et al. (eds.) (1999), Céramique et peinture grecques. Modes d'emploi, Actes du colloque international, École du Louvre, 26, 27, 28 avril 1995, Paris, 195-205.

Magrath, William T. (1977), “The Antaios Myth in Pindar," TAPhA 107, 203-224.

Malagardis, Athanasia (1985), “Deux temps d'une fête athénienne sur un skyphos attique,” $A K 28$, 71-92.

Malagardis, Nassi (1986), Skyphoi attiques à figures noires: Typologie et recherches, Ph.D. Diss., Université Paris I. 
Malagardis, Nassi (1997), “'Attic Vases, Etruscan Stories,' - Les échanges et les hommes. Origine, vie brève et mort d'une forme de vase attique archaïque," in John H. Oakley/William, D. E. Coulson/ Olga Palagia (eds.), Athenian Potters and Painters I, The Conference Proceedings, Oxford/ Oakville, 35-53.

Malagardis, Nassi (2008), "Introduction: Origine et evolution du gobelet: Chytridion ou mastoid?," in Nassi Malagardis/Athéna Tsingarida (eds.), Céramique attique archaïque. Gobelets "mastoïdes" à figures noires et rouges, CVA France 41, Musée du Louvre 27, Paris, 15-26.

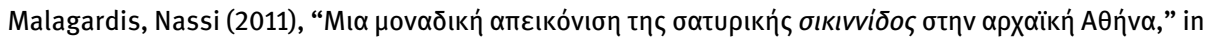
Angelos Delivorrias/George Despinis/Angelos Zarkadas (eds.), 'Enaıvo ५uigi Beschi, Athens, 233-248.

Malek, Amina-Aïcha (2008), “Un sacrifice manqué à Lambèse,” $R A 46,283-291$.

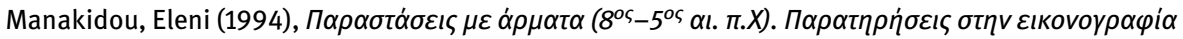
tous, Thessaloniki.

Mangold, Meret (2000), Kassandra in Athen: Die Eroberung Trojas aufattischen Vasenbildern, Berlin. Manuwald, Bernd (2007), "Wundergeschichten aus dem Asklepios-Heiligtum von Epidauros. Dokumente eines religiösen Kommunikationssystems," in Christian Frevel/Henner von Hesberg (eds.), Kult und Kommunikation. Medien in Heiligtümern der Antike, Wiesbaden, 89-120.

Manville, Brook (1990), The Origins of Citizenship in Ancient Athens, Princeton.

Manville, Brook/Ober, Josiah (2003), A Company of Citizens. What the World's First Democracy Teaches Leaders about Creating Great Organizations, Boston.

Marconi, Clemente (1994), Selinunte. Le metope dell'Heraion, Modena.

Mark, Ira S. (1993), The Sanctuary of Athena Nike in Athens: Architectural Stages and Chronology, Hesperia Supplement 26, Princeton.

Mark, Ira S. (1995), “Levels Taken on the Nike Bastion," Hesperia 64, 383-389.

Markoe, Glenn (1985), Phoenician Bronze and Silver Bowls from Cyprus and the Mediterranean, Berkeley.

Marlowe, Elizabeth (2006), "Framing the Sun: The Arch of Constantine and the Roman Cityscape," ABull 88, 223-242.

Martin, Roland/Metzger, Henri (1942/43), "Chronique des fouilles et découvertes archéologiques en Grèce en 1942: Épidaure,” $B C H$ 66/67, 327-334.

Marx, Patricia A. (2011), "Athens NM Acropolis 923 and the Contest between Athena and Poseidon for the Land of Attica," AK 54, 21-40.

Massa Pairault, Françoise-Hélène (1972), Recherches sur quelches séries d'urnes de Volterra à représentations mythologiques, Paris.

Matheson, Susan B. (1994), An Obsession with Fortune. Tyche in Greek and Roman Art, Exhibition Catalogue, New Haven.

Matheson, Susan B. (1995), Polygnotos and Vase Painting in Classical Athens, Madison.

Matheson, Susan B. (2005), "A Farewell with Arms: Departing Warriors on Athenian Vases," in Judith M. Barringer/Jeffrey M. Hurwit (eds.), Periklean Athens and its Legacy: Problems and Perspectives, Austin, 23-35.

Matheson, Susan B. (2009), "Old Age in Athenian Vase-painting," in John H. Oakley/Olga Palagia (eds.), Athenian Potters and Painters II, The Conference Proceedings, Oxford/Oakville, 192-200.

Matz, Friedrich/Duhn, Friedrich Karl von (1881), Antike Bildwerke in Rom: Mit Ausschluss der grösseren Sammlungen, Vol. 2, Leipzig.

Maximova, M. I. (1927), Les vases plastiques dans l'antiquité, Paris.

Mayo, Margaret Ellen/Hamma, K. (eds.) (1982), The Art of South Italy. Vases from Magna Graecia, Richmond, VA.

McCully, Marilyn (ed.) (1998), Picasso: Painter and Sculptor in Clay, Exhibition Catalogue New York, Metropolitan Museum of Art, London. 
McGovern, Patrick E. (2007), Ancient Wine. The Search for the Origins of Viniculture, Princeton.

McGowan, Elizabeth P. (1995), “Tomb Marker and Turning Post: Funerary Columns in the Archaic Period," AJA 99, 615-632.

McNally, Sheila (1978), “The Maenad in Early Greek Art,” Arethusa 11, 101-135.

McParland, Edward (1973), "Building in the Grand Manner, Sir Richard Morrison's Country Houses II," Country Life 153.3962, May 31, 1538-1541.

McPhee, Ian (1997), “Stemless Bell-kraters from Ancient Corinth,” Hesperia 66, 99-145.

Meijden, Hellebora van der (1993), Terrakotta-Arulae aus Sizilien und Unteritalien, Amsterdam.

Melfi, Milena (2007), I santuari di Asclepio in Grecia. I. Studia Archaeologica 157, Rome.

Melfi, Milena (2010), "Rebuilding the Myth of Asklepios at the Sanctuary of Epidauros in the Roman Period," in Athanassios D. Rizakis/ Claudia E. Lepenioti (eds.), Roman Peloponnese III.

Society, Economy, and Culture under the Roman Empire: Continuity and Innovation, Athens, 329-339.

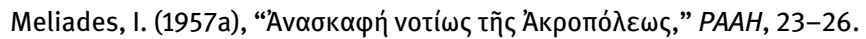

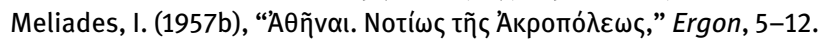

Mellor, Ronald (1978), “The Dedications on the Capitoline Hill,” Chiron 8, 319-330.

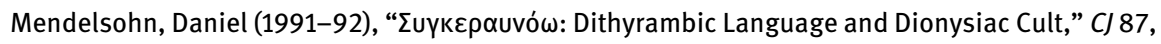
105-124.

Menninger, Michael (1996), Untersuchungen zu den Gläsern und Gipsabgüssen aus dem Fund von Begram (Afghanistan), Würzburg.

Mertens, Joan R. (1977), Attic White-Ground: Its Development on Shapes Other than Lekythoi, New York.

Mertens, Joan R. (2010), How to Read Greek Vases, New York/New Haven.

Mertens-Horn, Madeleine (1988), Die Löwenkopf-Wasserspeier des griechischen Westens im 6. und 5. Jahrhundert v. Chr im Vergleich mit den Löwen des griechischen Mutterlandes, Mainz.

Metzger, Henri (1951), Les représentations dans la céramique attique du IVe siècle, Paris.

Meyboom, Paul G. P. (1995), The Nile Mosaic of Palestrina. Early Evidence of Egyptian Religion in Italy, Leiden.

Meyer, Marion (1988), “Erfindung und Wirkung. Zum Asklepios Giustini,” MDAI(A) 103, 119-159.

Meyer, Marion (2012), “Der Heros als Alter Ego des Kriegers in archaischer und klassischer Zeit," AK 55, 25-51.

Mikalson, Jon D. (1998), Religion in Hellenistic Athens, Berkeley/Los Angeles/London.

Mikalson, Jon D. (2007), "Gods and Athletic Games," in Olga Palagia/Alkestis Choremi-Spetsieri (eds.), The Panathenaic Games, Proceedings of an International Conference held at the University of Athens, May 11-12, 2004, Oxford 2007, 33-40.

Miles, Margaret M. (2008), Art as Plunder: The Ancient Origins of Debate About Cultural Property, Cambridge.

Miller, Margaret C. (1995), “Priam, King of Troy," in Jane Carter/Sarah Morris (eds.), The Ages of Homer: A Tribute to Emily Townsend Vermeule, Austin, 449-465.

Miller, Margaret C. (1999), “Reexamining Transvestism in Archaic and Classical Athens: The Zewadski Stamnos,” AJA 103, 223-253.

Miller, Stephen G. (1974), “The Altar of the Six Goddesses in Thessalian Pherai,” CSCA 7, 231-256.

Miller, Stephen G. (1980), "Turns and Lanes in the Ancient Stadium," AJA 84, 159-166.

Miller, Stephen G. (1992), “The Bath,” in Darice E. Birge/Lynn H. Kraynak/Stephen G. Miller, Excavations at Nemea I. Topographical and Architectural Studies: The Sacred Square, the Xenon, and the Bath, Berkeley, 188-262.

Mills, Sophie (1997), Theseus, Tragedy, and the Athenian Empire, Oxford.

Milne, Marjorie (1988), “Appendix III: The Poem Entitled “Kiln,”” in Joseph Veach Noble (ed.), The Techniques of Painted Attic Pottery, London/New York, 186-196.

Milnor, Kristina (2005), Gender, Domesticity, and the Age of Augustus: Inventing Private Life, Oxford. 
Minor, Heather Hyde (1999), “Mapping Mussolini: Ritual and Cartography in Public Art during the Second Roman Empire," Imago Mundi 51, 147-162.

Miquel, Claire (1992), “Images d'Hermès,” in Christianne Bron/Effy Kassapoglou (eds.), L'Image en jeu: De l'antiquité à Paul Klee, Lausanne, 13-23.

Mirto, Maria Serena (2012), Death in the Greek World from Homer to the Classical Age, trans. by A. M. Osborne, Norman, OK.

Mitchell, Alexandre G. (2009), Greek Vase-Painting and the Origins of Visual Humour, Cambridge.

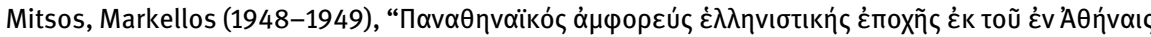

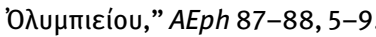

Mitten, David Gordon (2003), "Red-Figure Neck-Amphora with Nereus," in J. Michael Padgett (ed.), The Centaur's Smile: The Human Animal in Early Greek Art, Exhibition Catalogue, Princeton University Art Museum, New Haven, 346-348.

Mommsen, Heide (2002), “Das Tritonabenteuer bei Exekias,” in Andrew J. Clark/Jasper Gaunt (eds.), Essays in Honor of Dietrich von Bothmer, Allard Pierson Series 14, Amsterdam, 225-232.

Mommsen, Heide (2009), “Prometheus oder Atlas? Zur Deutung der Amphora München 1540,” in John H. Oakley/Olga Palagia (eds.), Athenian Potters and Painters II, The Conference Proceedings, Oxford/Oakville, 201-211.

Monaco, Maria Chiara (1995), “Syssitia. Ceramica da mensa dall'angolo nord-occidentale dell'Agorà ateniese," AION(archeol) 2, 133-140.

Monaco, Maria Chiara (2001), "Contributi allo studio di alcuni santuari ateniesi, I: Il temenos del Demos e delle Charites," ASAA 79, 103-150.

Moon, Warren G. (ed.) (1983), Ancient Greek Art and Iconography, Madison.

Moon, Warren G./Berge, Louise (eds.) (1979), Greek Vase Painting in Midwestern Collections, Chicago.

Moore, Mary B. (1980), “Exekias and Telamonian Ajax,” AJA 84, 417-434.

Moore, Mary B. (1997), Attic Red-figured and White-ground Pottery, The Athenian Agora 30, Princeton. Moore, Mary B. (2000), “The Berlin Painter and Troy," Greek Vases in the J. Paul Getty Museum 6, Occasional Papers on Antiquities 9, Malibu, 159-186.

Moore, Mary B. (2004), "Horse Care as Depicted on Greek Vases before 400 B.C.,” MMJ 39, 35-67.

Moore, Mary B. (2008), “The Hegesiboulos Cup,” MMJ 43, 11-37.

Moore, Mary B. (2010), "Hephaistos Goes Home: An Attic Black-figured Column-krater in the Metropolitan Museum," MMJ 45, 21-54.

Moore, Mary B. (2011), “Kleitias, Dionysos, and Cheiron,” BABesch 86, 1-13.

Moore, Mary B./Philippides, Mary Zelia (1986), Attic Black-figured Pottery, The Athenian Agora 23, Princeton.

Morandi, Alessandro (1982), "Scavi nella Tenuta di Pianabella di Ostia antica - 1976/77. Gli edifici sepolcrali," MPAA 14, 57-75.

Moraw, Susan (1998), Die Mänade in der attischen Vasenmalerei des 6. und 5. Jahrhunderts v. Chr. Rezeptionsästhetische Analyse eines antiken Weiblichkeitsentwurfs, Mainz.

Moreno, Paolo (1999), Sabato in Museo. Letture di arte ellenistica e romana, Milan.

Moret, Jean-Marc (1975), L'llioupersis dans la céramique italiote, les mythes et leurs expression figurée au IVe siècle, Rome.

Moretti, Gabriella (1948), Ara Pacis Augustae, Rome.

Morgan, Charles H. (1962), “The Sculptures of the Hephaisteion, I," Hesperia 31, 210-219.

Morgan, Janett (2010), The Classical Greek House. Greece and Rome Live, Exeter.

Morgan, Kathryn A. (2012), “A Prolegomenon to Performance in the West," in Kathryn Bosher (ed.), Theater Outside Athens: Drama in Greek Sicily and South Italy, Cambridge, 35-55.

Morison, William S. (2000), "An Honorary Deme Decree and the Administration of a Palaistra in Kephissia,” ZPE 131, 93-98. 
Morris, Sarah (1992), “Greece beyond East and West: Perspectives and Prospects," in Günter Kopcke/Isabelle Tokumaru (eds.), Greece Between East and West: $10^{\text {th }}-8^{\text {th }}$ Centuries BC, Mainz, xiii-xviii.

Morris, Sarah (2003), “Imaginary Kings: Alternatives to Monarchy in Early Greece,” in Kathryn A. Morgan (ed.), Popular Tyranny: Sovereignty and its Discontents in Ancient Greece, Austin, 1-24.

Morris, Sarah (2013), “From Kizzuwatna to Troy? Puduhepa, Piyamaradu, and Anatolian Ritual in Homer," in Stephanie Jamison/H. Craig Melchert/Brent Vine (eds.), Proceedings of the $24^{\text {th }}$ Annual UCLA Indo-European Conference, Bremen, 151-167.

Morris, Sarah/Papadopoulos, John K. (1998), "Phoenicians and the Corinthian Pottery Industry," in Renate Rolle/Karin Schmidt (with Roald Docter) (eds.), Archäologische Studien in Kontaktzonen der Antiken Welt. Festschrift: Hans-Georg Niemeyer, Hamburg, 251-263.

Mösch-Klingele, Rosemarie (2010), Braut ohne Bräutigam: Schwarz- und rotfigurige Lutrophoren als Spiegel gesellschaftlicher Veränderungen in Athen, Mainz.

Most, Glenn (1999), “From Logos to Mythos," in Richard Buxton (ed.), From Myth to Reason? Studies in the Development of Greek Thought, Oxford, 25-50.

Mountjoy, Penelope (1995), Mycenaean Athens, Jonsered.

Mulgan, Richard G. (1974), “Aristotle's Doctrine that Man is a Political Animal,” Hermes 102, 438-445.

Müller, Carl Werner (1994), “Das Bildprogramm der Silberbecher von Hoby. Zur Rezeption frühgriechischer Literatur in der römischen Bildkunst der augusteischen Zeit,” JDA/ 109, 1994, 321-352.

Müller, Jan Marius (2010), ““ ... weihte es der Athena': Basen von Weihgeschenken für Athena auf der nachklassischen Akropolis," in Ralf Krumeich/Christian Witschel (eds.), Die Akropolis von Athen im Hellenismus und in der römischen Kaiserzeit, Wiesbaden, 157-217.

Murphy, Cullen (2007), Are We Rome? The Fall of an Empire and the Fate of America, Boston.

Murray, A. T. (trans.) (1924), Homer, 2 vols., Cambridge, MA.

Murray, Oswyn (1990), “Sympotic History," in Oswyn Murray (ed.), Sympotica. A Symposium on the Symposion, Oxford, 3-13.

Muth, Susanne (2000), “Gegenwelt als Glückswelt - Glückswelt als Gegenwelt? Die Welt der Nereiden, Tritonen und Seemonster in der römischen Kunst,” in Tonio Hölscher (ed.), Gegenwelten: Zu den Kulturen Griechenlands und Roms in der Antike, Munich, 467-498.

Muth, Susanne (2004), “Das Grausen des Minotauros. Eine Gratwanderung der Monster-Ikonographie in der klassischen Bildkunst Athens,” Münchner Jahrbuch der bildender Kunst 55, 7-31.

Muth, Susanne (2008), Gewalt im Bild. Das Phänomen der medialen Gewalt im Athen des 6. und 5. Jahrhunderts v. Chr., Berlin.

Nafissi, Massimo (1986), “Distribuzione della ceramica laconica,” in Studi sulla ceramica laconica, Atti del Seminario Perugia, 23-24 febbraio 1981, Archaeologia Perusina vol. 3, Archaeologica 66, Rome, 149-172.

Nagy, Gregory (1973), “Phaethon, Sappho’s Phaon, and the White Rock of Leukas,” HSPh 77, 137-177.

Nagy, Helen (2013), “Landscape and Illusionism: Qualities of Etruscan Wall Paintings,” in Jean MacIntosh Turfa (ed.), The Etruscan World, London/New York, 1017-1025.

Naso, Alessandro (ed.) (2006), Stranieri e non Cittadini nei Santuari Greci, Atti del Convegno Internazionale, Florence.

Neale, John Preston (1829), Views of the Seats of Noblemen and Gentlemen in England, Wales, Scotland and Ireland, Vol. 2, London.

Neer, Richard T. (1998), “Imitation, Inscription, Antilogic,” Métis 13, 17-38.

Neer, Richard T. (2002), Style and Politics in Athenian Vase-Painting. The Craft of Democracy, ca. 530-460 B.C.E., Cambridge.

Neer, Richard T. (2004), “The Athenian Treasury at Delphi and the Material of Politics," ClAnt 23, 63-94.

Neer, Richard T. (2010), The Emergence of the Classical Style in Greek Sculpture, Chicago. 
Neils, Jenifer (1981), in H. A. (H. Alan) Shapiro (ed.), Art, Myth, and Culture: Greek Vases from Southern Collections, Exhibition Catalogue, New Orleans Museum of Art and Tulane University, New Orleans, 84-87.

Neils, Jenifer (1987), The Youthful Deeds of Theseus, Rome.

Neils, Jenifer (1992), "Panathenaic Amphoras: Their Meaning, Makers, and Markets," in Jenifer Neils (ed.), The Goddess and the Polis. The Panathenaic Festival in Ancient Athens, Hanover, 29-51 and 143-193.

Neils, Jenifer (2000), "Others Within the Other: An Intimate Look at Hetairai and Maenads," in Beth Cohen (ed.), Not the Classical Ideal: Athens and the Construction of the Other in Greek Art, Leiden, 203-226.

Neils, Jenifer (2001), The Parthenon Frieze, Cambridge.

Neils, Jenifer (2009a), "Beloved of the Gods: Imag(in)ing Heroes in Greek Art," in Sabine Albersmeier (ed.), Heroes: Mortals and Myths in Ancient Greece, Exhibition Catalogue, Walters Art Museum, Baltimore 2010, 108-119.

Neils, Jenifer (2009b), “Textile Dedications to Female Deities: The Case of the Peplos," in Clarisse Prêtre (ed.), Le donateur, l'offrande et la déesse: Systèmes votifs dans les sanctuaires de déesses du monde grec, Kernos Supplement 23, Liège, 135-147.

Neils, Jenifer (2011), Women in the Ancient World, Los Angeles.

Neils, Jenifer/Oakley, John H. (eds.) (2003), Coming of Age in Ancient Greece. Images of Childhood from the Classical Past, New Haven.

Neils, Jenifer/Oakley, John H./Shapiro, H. A. (H. Alan) (2001), "Appendix 3: List of Attic Red-figured Amphorae of Panathenaic Form," in Martin Bentz/Norbert Eschbach (eds.), Panathenaïka. Symposion zu den Panathenäischen Preisamphoren, Rauischholzhausen 25.11.-29.11.1998, Mainz, 199-202.

Nesselrath, Heinz-Günther (1990), Die attische mittlere Komödie. Ihre Stellung in der antiken Literaturkritik und Literaturgeschichte, Berlin.

Neumann, Gerhard (1965), Gesten und Gebärden in der griechischen Kunst, Berlin.

Nevett, Lisa C. (1999), House and Society in the Ancient Greek World, Cambridge.

Nevett, Lisa C. (2010), Domestic Space in Classical Antiquity, Cambridge.

Nicolet, Claude (1991), Space, Geography, and Politics in the Early Roman Empire, Ann Arbor.

Nielsen, Inge (1990), Thermae et Balnea: The Architecture and Cultural History of Roman Public Baths, Aarhus.

Nielsen, Marjatta (1993), “Cultural Orientation in Etruria in the Hellenistic Period: Greek Myths and Local Motifs on Volterran Urn Reliefs," in Pia Guldager Bilde/Inge Nielsen/Marjatta Nielsen (eds.), Aspects of Hellenism in Italy: Towards a Cultural Unity?, Acta Hyperborea 5, Copenhagen, 319-357.

Nilsson, Martin P. (1916), “Die Prozessionstypen im griechischen Kult,” JDA/31, 309-339.

Oakley, John H. (1982), "Athamas, Ino, Hermes, and the Infant Dionysos: A Hydria by Hermonax," AK 25, 44-47.

Oakley, John H. (1988), “Attic Red-figured Skyphoi of Corinthian Shape,” Hesperia 57, 165-191.

Oakley, John H. (1990), The Phiale Painter, Mainz.

Oakley, John H. (2001), “Charon on an Attic Red-figure Amphora of Panathenaic Shape: A Masterpiece by the Kleophon Painter in Quebec," in Martin Bentz/Norbert Eschbach (eds.), Panathenaïka. Symposion zu den Panathenäischen Preisamphoren, Rauischholzhausen 25.11.-29.11.1998, Mainz, 137-143.

Oakley, John H. (2004), Picturing Death in Classical Athens: The Evidence of the White Lekythoi, Cambridge.

Oakley, John H. (2007), “A Unique New Depiction of a Panathenaic Victor," in Olga Palagia/Alkestis Choremi-Spetsieri (eds.), The Panathenaic Games, Proceedings of an international conference held at the University of Athens, May 11-12, 2004, Oxford, 81-90. 
Oakley, John H. (2008), “Women in Athenian Ritual and Funerary Art,” in Nikolaos Kaltsas/Alan Shapiro (eds.), Worshiping Women: Ritual and Reality in Classical Athens, New York, 335-341.

Oakley, John H. (2010), “Child Heroes in Greek Art,” in Sabine Abersmeier (ed.), Heroes. Mortals and Myths in Ancient Greece, Exhibition Catalogue, Baltimore 2010, 66-87.

Oakley, John H. (2011), “Sabouroff-Maler,” DNP 10, 1192-1193.

Oakley, John H./Sinos, Rebecca H. (1993), The Wedding in Ancient Athens, Madison.

Ober, Josiah (1989), Mass and Elite in Democratic Athens: Rhetoric, Ideology, and the Power of the People, Princeton.

Olmos, Ricardo (1993), Catálogo de los vasos griegos del Museo Nacional de Bellas Artes de La Habana, Madrid.

Orshefsky, Milton (1971), “Party at Persepolis,” Life Magazine, October 15.

Orsi, Paolo (1917), “Locri Epiz.: Campagne di scavo nella necropoli Lucifero negli anni 1914 e 1915,” NSA 14, 101-167.

Osborne, Michael J./Byrne, Sean G. (eds.) (1994), A Lexicon of Greek Personal Names, Vol. II, Oxford.

Osborne, Robin (1997), "The Ecstasy and the Tragedy: Varieties of Religious Experience in Art, Drama, and Society," in Christopher Pelling (ed.), Greek Tragedy and the Historian, Oxford, 187-211.

Osborne, Robin (2002), “Archaic Greek History,” in Egbert J. Bakker/Irene J. F. de Jong/Hans van Wees (eds.), Brill's Companion to Herodotus, Leiden, 497-520.

Oswald, Alice (2011), Memorial: A Version of Homer's Iliad, New York.

Otterman, Michael (2007), American Torture: From the Cold War to Abu Ghraib and Beyond, London.

Padgett, J. Michael (2001), “Ajax and Achilles on a Calyx-Krater by Euphronios,” Record of the Art Museum, Princeton University 60, 2-17.

Padgett, J. Michael (2002), “A Unique Vase in the Metropolitan Museum of Art,” in Andrew J. Clark/ Jasper Gaunt (eds.), Essays in Honor of Dietrich von Bothmer, Amsterdam, 249-266.

Padgett, J. Michael (2007), “Tyrrhenian Amphora,” in Princeton University Art Museum: Handbook of the Collections, Princeton, 76-77.

Padgett, J. Michael (ed.) (2003), The Centaur's Smile: The Human Animal in Early Greek Art, Exhibition Catalogue, Princeton.

Page, Denis (1962), Poetae Melici Graeci, Oxford.

Pala, Elisabetta (2012), Acropoli di Atene. Un microcosmo della produzione e distribuzione della ceramica attica, Rome.

Palagia, Olga (1990), “A New Relief of the Graces and the Charites of Socrates,” in M. Geerard (ed.), Opes Atticae, Miscellanea philologica et historica Raymondo Bogaert et Hermanno Van Looy oblata, The Hague, 347-356.

Palagia, Olga (2000a), “A Gymnasiarch's Dedication and the Panathenaic Torch-race,” in $\alpha \gamma \alpha \theta \dot{\varsigma} \varsigma$

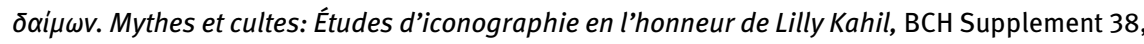
Paris, 403-408.

Palagia, Olga (2000b), "Meaning and Narrative Techniques in Statue-bases of the Pheidian Circle," in N. Keith Rutter/Brian A. Sparkes (eds.), Word and Image in Ancient Greece, Edinburgh, 53-78.

Palagia, Olga (2005a), “Fire from Heaven: Pediments and Akroteria of the Parthenon,” in Jenifer Neils (ed.), The Parthenon from Antiquity to the Present, Cambridge, 225-259.

Palagia, Olga (2005b), “Interpretations of two Athenian Friezes. The Temple on the Ilissos and the Temple of Athena Nike," in Judith M. Barringer/Jeffrey M. Hurwit (eds.), Periklean Athens and its Legacy. Problems and Perspectives, Austin, 177-192.

Palagia, Olga (2008), "Women in the Cult of Athena," in Nikolaos Kaltsas/H. A. (H. Alan) Shapiro (eds.), Worshiping Women: Ritual and Reality in Classical Athens, New York, 31-37.

Palagia, Olga (2009), “Archaism and the Quest for Immortality in Attic Sculpture during the Peloponnesian War," in Olga Palagia (ed.), Art in Athens during the Peloponnesian War, Cambridge, 24-51. 


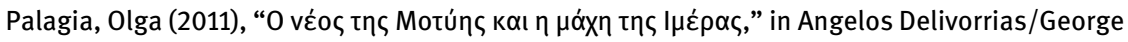
Despinis/Angelos Zarkadas (eds.), 'Enaıvo Luigi Beschi, Athens, 283-293.

Palagia, Olga (2014), "Statues on Columns Flanking Athena and the Archonship of Souniades (397/6

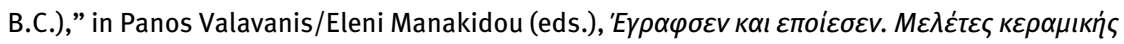

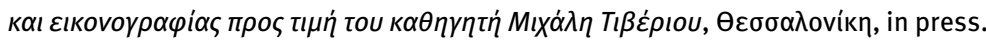

Palagia, Olga/Lewis, David (1989), "The Ephebes of Erechtheis 333/2 B.C. and their Dedication," ABSA 84, 333-344.

Paleothodoros, Dimitris (2009), "Archaeological Contexts and Iconographic Analysis: Case Studies from Greece and Etruria," in Vinnie Nørskow et al. (eds.), The World of Greek Vases, Rome, 45-62.

Paleothodoros, Dimitrios (ed.) (2012), The Contexts of Painted Pottery in the Ancient Mediterranean World (Seventh-Fourth centuries BC), BAR International Series 2364, 0xford.

Panofsky, Erwin (1969), Problems in Titian, Mostly Iconographic, New York.

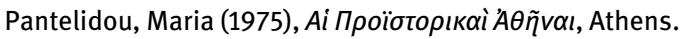

Panvini, Rosalba/Giudice, Filippo (eds.) (2003), TA ATTIKA. Veder greco a Gela. Ceramiche attiche figurate dall'antica colonia, Exhibition Catalogue, Gela, Syracuse, Rhodes 2004, Rome.

Paolucci, Giulio (1996), Sinalunga e Bettolle. Due centri etruschi della Val di Chiana, Sinalunga.

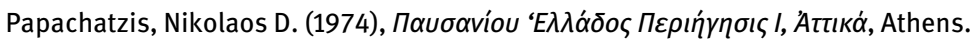

Papadakis, Manuela (1994), Ilias- und Iliupersisdarstellungen auffühen rotfigurigen Vasen, Frankfurt.

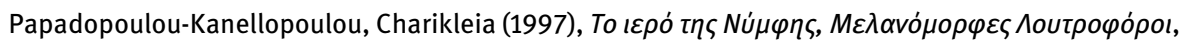
Athens.

Papakonstantinou, Zinon (2002), “Prizes in Early Archaic Greek Sport,” Nikephoros 15, 51-67.

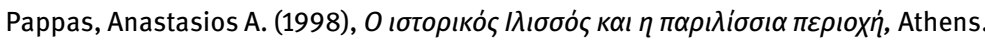

Parca, Maryline (1991), Ptocheia, or Odysseus in Disguise at Troy (P. Köln VI 245), American Studies in Papyrology 31, Atlanta.

Paribeni, Enrico (1992), "Note sul cratere a volute," in Mario Cygielman et al. (ed.), Euphronios, Atti del Seminario internazionale di studi, Arezzo, 27-28 maggio 1990, Florence, 19-21.

Parisi Presicce, Claudio (1993), “Cratere a calice con scena mitologica," in Riscoprire Pompei. Exhibition Catalogue, Rome, 222-224.

Parke, Herbert W. (1977), Festivals of the Athenians, Ithaca, NY.

Parker, Robert (1983), Miasma: Pollution and Purification in Early Greek Religion, Oxford.

Parker, Robert (1996), Athenian Religion. A History, Oxford.

Parker, Robert (2005), Polytheism and Society at Athens, Oxford.

Pasquier, Alain (1999), "Un cratère-rafraîchissoir au Musée du Louvre: Du vin frais pour un banquet de luxe," MMAI 78, 5-51.

Patton, Kimberley C. (2009), Religion of the Gods. Ritual, Paradox, and Reflexivity, Oxford.

Paul-Zinserling, Verena (1994), Der Jena-Maler und sein Kreis: Zur Ikonologie einer attischen Schalenwerkstatt um 400 v. Chr., Mainz.

Pavese, Carlo O. (1996), L'auriga di Mozia, Rome.

Pease, Mary Zelia (1935), “The Pottery from the North Slope of the Acropolis," Hesperia 2, 214-302.

Peck, A. L. (trans.) (1942), Aristotle. Generation of Animals, Cambridge, MA.

Peek, Werner (1972), Neue Inschriften aus Epidauros, Berlin.

Peirce, Sarah (1998), "Visual Language and Concepts of Cult on the 'Lenaia Vases,"' ClAnt 17, 59-95.

Pellegrini, Elisa (2009), Eros nella Grecia arcaica e classica, iconografia e iconologia, Rome.

Pellizer, Ezio (1990), “Outlines of a Morphology of Sympotic Entertainment," in Oswyn Murray (ed.), Sympotica. A Symposium on the Symposion, Oxford, 177-184.

Peppa-Papaioannou, Irene (1990), “New Archaeological Evidence for Water Supply and Drainage System of the Asklepieion at Epidauros," in Akten des XIII. Internationalen Kongresses für Klassische Archäologie, Berlin 1988, Mainz, 553-554. 


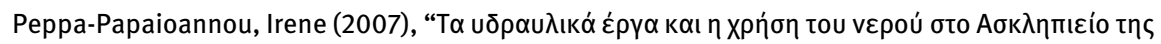

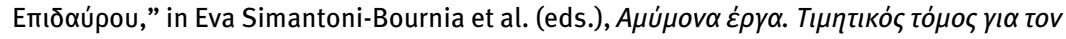

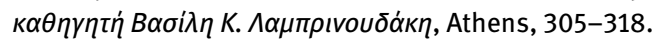

Percy, William A. (1996), Pederasty and Pedagogy in Archaic Greece, Urbana and Chicago.

Pernice, Erich (1897), "Die korinthischen Pinakes im Antiquarium der Königlichen Museen," JDAI 12, 9-48.

Perrin-Seminadayar, Éric (2007), Éducation, Culture et Société à Athènes. Les acteurs de la vie culturelle athénienne (229-88), Paris.

Pesando, Fabrizio (1987), Oikos e Ktesis. La casa greca in età classica, Perugia.

Peschel, Ingeborg (1987), Die Hetäre bei Symposion und Komos in der attisch-rotfigurigen Vasenmalerei des 6.-4. Jahrhunderts v. Chr., Frankfurt.

Petrakos, Basil (1996), Marathon, trans. by Alexandra Doumas, Athens.

Petrarulo, Gabriella (2012), "New Considerations Regarding the Seascape Fresco in the Tomb of the Ship (Tomba della Nave) at Tarquinia," EtrStud 15, 115-145.

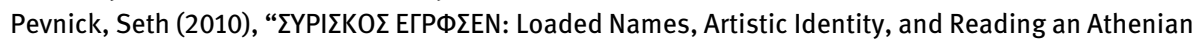
Vase," ClAnt 29, 222-253.

Pfister, Friedrich (1909), Der Reliquienkult im Altertum I: Das Objekt des Reliquienkultes, Giessen.

Pflaum, H.-G. (1950), Les procurateurs équestres sous le haut-empire romain, Paris.

Pfrommer, Michael (1996), "Roots and Contacts: Aspects of Alexandrian Craftsmanship," in Kenneth Hamma (ed.), Alexandria and Alexandrianism, Papers Delivered at a Symposium Organized by the J. Paul Getty Museum and the Getty Center for the History of Art and the Humanities and Held at the Museum, April 22-25, 1993, Malibu, 171-189.

Pfuhl, Ernst (1923), Malerei und Zeichnung der Griechen, Munich.

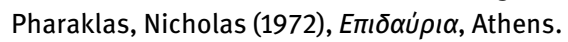

Philipp, Jayne H. (1991), The Asklepieion at Epidauros in Roman Times, M.A. Thesis, The Ohio State University.

Philipp, Jayne H. (1998), “The $99^{\text {th }}$ Annual Meeting of the Archaeological Institute of America. Session 3F: Cities and Spas in the Roman World: Roman Bathing in Greek Sanctuaries: A Consideration of the Baths at Epidauros," AJA 102, 395.

Pickard-Cambridge, Arthur W. (1968), The Dramatic Festivals of Athens, $2^{\text {nd }}$ edn. rev. by John Gould/ D. M. Lewis, Oxford.

Picón, Carlos et al. (2007), Art of the Classical World in the Metropolitan Museum of Art, New York/ London.

Pipili, Maria (1987), Laconian Iconography of the Sixth Century B.C., Oxford University Committee for Archaeology, Monograph 1, Oxford.

Pipili, Maria (2000), “Wearing an Other Hat: Workmen in Town and Country," in Beth Cohen (ed.), Not the Classical Ideal. Athens and the Construction of the Other in Greek Art, Leiden, 150-179.

Pollard, John (1977), Birds in Greek Life and Myth, London/New York.

Pollitt, J. J. (1990), The Art of Ancient Greece: Sources and Documents, Cambridge.

Pollitt, J. J. (1997), “The Meaning of the Parthenon Frieze," in Diana Buitron-Oliver (ed.), The Interpretation of Architectural Sculpture in Greece and Rome, Washington, DC, 51-65.

Pottier, Edmond (1901), Vases antiques du Louvre II, Paris.

Prange, Matthias (1989), Der Niobidenmaler und seine Werkstatt. Untersuchungen zu einer Vasenwerkstatt frühklassischer Zeit, Frankfurt.

Premerstein, Adolf von (1912), "Der Parthenonfries und die Werkstatt des panathenäischen Peplos," JÖAl 15, 1-35.

Pucci, Pietro (1998), The Song of the Sirens: Essays on Homer, Lanham, MD.

Raab, Ingrid (1972), Zu den Darstellungen des Parisurteils in der griechischen Kunst, Frankfurt. 
Raaflaub, Kurt (1998), “The Transformation of Athens in the Fifth Century," in Deborah Boedeker/Kurt Raaflaub (eds.), Democracy, Empire, and the Arts in Fifth-Century Athens, Cambridge, MA, 15-42.

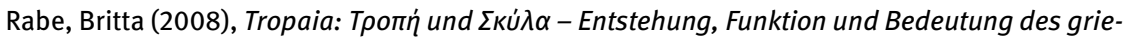
chischen Tropaions, Tübingen.

Rackham, H. (trans.) (1932), Aristotle. Politics, Cambridge, MA.

Radt, Wolfgang (1999), Pergamon. Geschichte und Bauten einer antiken Metropole, Darmstadt.

Raepsaet-Charlier, Marie-Thérèse (1982), "Epouses et familles de magistrats dans les provinces romaines aux deux premiers siècles de l'empire," Historia 31, 56-69.

Raglan, Lord (1936), The Hero. A Study in Tradition, Myth and Drama, London.

Rank, Otto (1987), Il mito della nascita dell'eroe, Reprint [1909], Milan.

Raubitschek, Antony E. (1949), Dedications from the Athenian Acropolis. A Catalogue of the Inscriptions of the Sixth and Fifth centuries B.C., Cambridge, MA.

Raubitschek, Antony E. (1959), "A Note on the Inscription on the Plaster Cast," Record of The Art Museum, Princeton University, 18.2, 60.

Ready, Jonathan L. (2007), “Homer, Hesiod, and the Epic Tradition,” in H. A. (H. Alan) Shapiro (ed.), The Cambridge Companion to Archaic Greece, Cambridge, 111-140.

Reber, Karl (1989), "Zur architektonischen Gestaltung der Andrones in den Häusern von Eretria," AK 32, 3-7.

Reber, Karl (1998), Die klassischen und hellenistischen Wohnhäuser im Westquartier, Eretria 10, Lausanne.

Recke, Matthias (2002), Gewalt und Lied: Das Bild des Krieges bei den Athenern im 6. und 5. Jh. v. Chr., Istanbul.

Reden, Sitta von (1995), Exchange in Ancient Greece, London.

Reeder, Ellen D. (1999), Scythian Gold. Treasures from Ancient Ukraine, Exhibition Catalogue, New York.

Reese, David (1995), “Equid Sacrifices/Burials in Greece and Cyprus: An addendum," JPR 9, 35-42.

Reich, Paula (2009), Toledo Museum of Art: Map \& Guide, $2^{\text {nd }}$ edn., London.

Reilly, Joan (1989), “Many Brides: 'Mistress and Maid' on Athenian Lekythoi," Hesperia 58, 411-444.

Reinhard, Jayne H. (2005), The Roman Bath at Isthmia. Decoration, Cult, and Herodes Atticus, Ph.D. Diss., University of Minnesota.

Reinsberg, Carola (1980), Studien zur hellenistischen Toreutik. Die antiken Gipsabgüsse aus Memphis, Hildesheim.

Reinsberg, Carola (1993), Ehe, Hetärentum und Knabenliebe im antiken Griechenland, Munich.

Renfrew, Jane M. (1995), "Palaeoethnobotanical Finds of Vitis from Greece," in Patrick E. McGovern/ Stuart J. Fleming/Solomon H. Katz (eds.), The Origin and Ancient History of Wine, Amsterdam, 255-267.

Reusser, Christoph (1993), Der Fidestempel aufdem Kapitol in Rom und seine Ausstattung, BullCom Supplement 2, Rome.

Reusser, Christoph (1995), “Fides populi Romani/Publica,” LTUR 2, 249-251.

Reynolds, Joyce M. (1981), "New Evidence for the Imperial Cult in Julio-Claudian Aphrodisias," ZPE 43, 317-327.

Reynolds, Joyce M. (1996), "Ruler-cult at Aphrodisias in the Late Republic and under the Julio-Claudian Emperors," in Alistair Small (ed.), Subject and Ruler: The Cult of the Ruling Power in Classical Antiquity, JRA Supplemental Series 17, Portsmouth, RI, 41-50.

Rhodes, Peter J./Osborne, Robin (2003), Greek Historical Inscriptions 404-323 BC, Oxford.

Ribéreau-Gayon, Pascal et al. (2006), Handbook of Enology, Vol. 1: The Microbiology of Wine and Vinifications, $2^{\text {nd }}$ edn., Chichester.

Riccioni, Giuliana (1953), “Due vasi del Pittore di Orfeo,” ArchClass 5, 248-251. 
Richter, Gisela M. A. (1946), Attic Red-Figured Vases. A Survey, New Haven.

Richter, Gisela M. A. (1953), Handbook of the Greek Collection, The Metropolitan Museum of Art, Cambridge, MA.

Richter, Gisela M. A. (1958), “Ancient Plaster Casts of Greek Metalware,” AJA 62 (1958) 369-377.

Richter, Gisela M. A. (1959), “A Plaster Cast of a Horse's Nose Piece,” Record of The Art Museum, Princeton University, 18.2, 53-59.

Richter, Gisela M. A. (1960), “An Ancient Plaster Cast in Munich,” in Felix Eckstein (ed.), Theoria. Festschrift für W.-H. Schuchhardt, Baden-Baden, 179-183.

Richter, Gisela M. A./Milne, Marjorie J. (1935), Shapes and Names of Athenian Vases, New York. Ridgway, Brunilde Sismondo (1970a), “Dolphins and Dolphin-Riders,” Archaeology 23, 86-95. Ridgway, Brunilde Sismondo (1970b), The Severe Style in Greek Sculpture, Princeton.

Ridgway, Brunilde Sismondo (1992), “Images of Athena on the Akropolis,” in Jenifer Neils (ed.), Goddess and Polis. The Panathenaic Festival in Ancient Athens, Princeton, 119-142.

Ridgway, Brunilde Sismondo (1995), “Lo stile severo. Lo stato della questione," in Nicola Bonacasa (ed.), Lo stile severo in Grecia e in Occidente: Aspetti e problemi, Rome, 35-42.

Riethmüller, Jürgen W. (2005), Asklepios. Heiligtümer und Kulte, 2 vols., Studien zu antiken Heiligtümern 2, Heidelberg.

Riethmüller, Jürgen W. (2009), “Review of Melfi, Milena (2007), I santuari di Asclepio in Grecia I, Studia archaeologica 157, Rome” AJA 113, online, (http://www.ajaonline.org/sites/default/files/ 08_Riethmuller.pdf).

Ritter, Stefan (2005), “Eros und Gewalt. Menelaos und Helena in der attischen Vasenmalerei des 5. Jhs. v. Chr.," in Günther Fischer/Susanne Moraw (eds.), Die andere Seite der Klassik. Gewalt im 5. und 4. Jahrhundert v. Chr., Kulturwissenschaftliches Kolloquium Bonn, Kunst- und Ausstellungshalle der Bundesrepublik Deutschland, 11.-13. Juli 2002, Stuttgart, 265-285.

Rizza, Giovanni/De Miro, Ernesto (1985), “Le arti figurative dalle origini al V secolo a.C,” in Giovanni Pugliese Carratelli (ed.), Sikanie. Storia e civiltà della Sicilia greca, Milan, 125-242.

Rizzo, Giulio E. (1946), Monete greche della Sicilia, Rome.

Robert, Carl (1920), Die Griechische Heldensage I, Berlin.

Robert, Carl (1921), Die Nationalheroen, Griechische Mythologie 2,2, ed. by Ludwig Preller, Berlin. Robertson, Martin (1970), “Ibycus: Polycrates, Troilus, Polyxena," BICS 17, 11-15.

Robertson, Martin (1990), "Troilos and Polyxene: Notes on a Changing Legend," in Jean-Paul Descoeudres (ed.), Eumousia: Ceramic and Iconographic Studies in Honour of Alexander Cambitoglou, Mediterranean Archaeology Supplement 1, Sydney, 63-70.

Robertson, Martin (1992), The Art of Vase-painting in Classical Athens, Cambridge.

Robinson, David Moore (1946), Domestic and Public Architecture, Excavation of Olynthus 12, Baltimore.

Robinson, David Moore/Graham, J. Walter (1938), The Hellenic House: A Study of the Houses Found at Olynthus, Excavation of Olynthus 8, Baltimore.

Robinson, David Moore/Freeman, Sarah Elizabeth (1936), “The Lewis Painter = Polygnotos II," AJA 40, 215-227.

Rodgers, René (2003), “Female Representation in Roman Art: Feminising the Provincial 'Other,”' in Sarah Scott/Jane Webster (eds.), Roman Imperialism and Provincial Art, Cambridge, 63-93.

Roebuck, Carl (1940), “Pottery from the North Slope of the Acropolis, 1937-1938," Hesperia 9, 141-260.

Roller, Matthew (2001), Constructing Autocracy: Aristocrats and Emperors in Julio-Claudian Rome, Princeton.

Roller, Matthew (2009), “The Exemplary Past in Roman Historiography and Culture,” in Andrew Feldherr (ed.), The Cambridge Companion to the Roman Historians, Cambridge, 214-230.

Rolley, Claude (1981), “Deux gorgones, deux problèmes. A propos de deux bronzes grecs du Louvre," RLouvre 31, 323-330. 
Rolley, Claude (1982), Les vases de bronze de l'archaïsme récent en Grand-Grèce, Naples.

Rolley, Claude (1983), Les bronzes grecs, Fribourg.

Rolley, Claude (1994), La sculpture grecque I: Des origins au milieu du Ve siècle, Paris.

Rolley, Claude (2000), "Review of Anja Sakowski, Darstellungen von Dreifusskesseln in der griechischen Kunst bis zum Beginn der klassischen Zeit, Archäologie 67, Frankfurt 1997," RA, 474-475.

Rolley, Claude (2003), La tombe princière de Vix, Paris.

Romano, David Gilman (2005), "A New Topographical and Architectural Survey of the Sanctuary of Zeus at Mount Lykaion," in Erik Ostby (ed.), Ancient Arcadia, Papers from the Third International Seminar on Ancient Arcadia, held at the Norwegian Institute at Athens, 7-10 May 2002, Bergen, 381-396.

Romano, Irene B. (2006), Catalogue of the Cypriot, Greek, and Roman Stone Sculpture in the University of Pennsylvania Museum of Archaeology and Anthropology, Philadelphia.

Root, Margaret Cool (1979), The King and Kingship in Achaemenid Art: Essays on the Creation of an Iconography of Empire, Leiden.

Roscino, Carmela (2003), “'’'immagine della tragedia: Elementi di caratterizzazione teatrale ed iconografia nella ceramica italiota e siceliota," in Luigi Todisco (ed.), La ceramica figurata a soggetto tragico in Magna Grecia e in Sicilia, Rome, 223-357.

Rose, Ch. Brian (1990), "Princes and Barbarians on the Ara Pacis," AJA 94, 453-467.

Rose, Ch. Brian (1997), Dynastic Commemoration and Imperial Portraiture in the Julio-Claudian Period, Cambridge.

Rose, Ch. Brian (2005), “The Parthians in Augustan Rome," AJA 109, 21-75.

Rose, Ch. Brian (2010), "Iconography," in Alessandro Barchiesi/Walter Scheidel (eds.), The Oxford Handbook of Roman Studies, Oxford, 49-76.

Rotroff, Susan I. (1982), Hellenistic Pottery. Athenian and Imported Moldmade Bowls, The Athenian Agora 22, Princeton.

Rotroff, Susan I. (1996), The Missing Krater and the Hellenistic Symposium. Drinking in the Age of Alexander the Great, Broadhead Classical Lecture 7, Canterbury.

Rotroff, Susan I. (2011), "Mended in Antiquity: Repairs to Ceramics at the Athenian Agora," in Mark L. Lawall/John Lund (eds.), Pottery in the Archaeological Record: Greece and Beyond, Acts of the International Colloquium Held at the Danish and Canadian Institutes in Athens, June 20-22, 2008, Aarhus, 117-134.

Roux, Georges (1961), L'architecture de l'Argolide aux IVe et IIle siècles avant J.-C, Bibliothèque des Écoles Françaises d'Athènes et de Rome 199, Paris.

Royal Athena Galleries (2001), Art of the Ancient World, Vol. 12, New York.

Rückert, Birgit (1998), Die Herme im öffentlichen und privaten Leben der Griechen. Untersuchungen zur Funktion der griechischen Herme als Grenzmal, Inschriftenträger und Kultbild des Hermes, Regensburg.

Rudolph, Wolf W. (1976), “HP 2310: A Lakonian Kylix from Halieis,” Hesperia 45, 240-252.

Rühfel, Hilde (1984), Das Kind in der Griechischen Kunst: Von der minoisch-mykenischen Zeit bis zum Hellenismus, Mainz.

Rühfel, Hilde (2003), Begleitet von Baum und Strauch: Griechische Vasenbilder, Dettelbach.

Rusten, Jeffrey S. (ed.) (1989), The Peloponnesian War: Book II, Cambridge.

Sabetai, Victoria (2008), “Women's Ritual Roles in the Cycle of Life," in Nikolaos Kaltsas/Alan Shapiro (eds.), Worshiping Women: Ritual and Reality in Classical Athens, New York, 289-297.

Sabetai, Victoria (2009), “Marker Vase or Burnt Offering? The Clay Loutrophoros in Context," in Athena Tsingarida (ed.), Shapes and Uses of Greek Vases ( $7^{\text {th }}-4^{\text {th }}$ Centuries B.C.), Brussels, 291-306. 
Sadurska, Anna (1990), Les monuments funéraires: Autels, urnes, stèles divers dans les collections polonaises. Corpus Signorum Imperii Romanii II 1, Warsaw.

Sakowski, Anja (1997), Darstellungen von Dreifusskesseln in der griechischen Kunst bis zum Beginn der klassischen Zeit, Archäologie 67, Frankfurt.

Salkever, Stephen G. (2005), “Aristotle's Social Science,” in Richard Kraut/Steven Skultety (eds.), Aristotle's Politics: Critical Essays, Lanham, MD, 27-64.

Salzmann, Dieter (1982), Untersuchungen zu den antiken Kieselmosaiken. Von den Anfängen bis zum Beginn der Tesseratechnik, Archäologische Forschungen 10, Berlin.

Sánchez Fernández, Carmen/Cabrera Bonet, P. (eds.) (1998), En los límites de Dioniso, Actas del simposio celebrado en el Museo Arqueológico Nacional Madrid 1997, Murcia.

Santi, Fabrizio (2010), I frontoni arcaici dell'Acropoli di Atene. Supplementi e Monografie della rivista ArchClass 4, Rome.

Sarti, Susanna (2001), Giovanni Pietro Campana 1808-1880: The Man and his Collection, BAR International Series 972, Oxford.

Sarti, Susanna (2003), “Le hydriai del Gruppo di Leagros nell’Antiquarium del Museo archeologico di Firenze," ArchCl 54, 23-67.

Satlow, Michael L. (2013), “Introduction,” in Michael L. Satlow (ed.), The Gift in Antiquity, Malden, MA, 1-11.

Sauge, André (2000), L'lliade, poème athénien de l'époque de Solon, Bern.

Saunders, David (2008), "Dead Warriors and their Wounds on Athenian Black-figure Vases," in Donna C. Kurtz (ed.), Essays in Classical Archaeology for Eleni Hatzivassiliou 1977-2007, BAR International Series 1796, Oxford, 85-94.

Saunders, Trevor John (1995), Aristotle: Politics Books I and II, Oxford, 1995.

Schadewaldt, Wolfgang (1928), "Zum Phrixos des Euripides," Hermes 63, 1-14.

Schäfer, Alfred (1997), Unterhaltung beim griechischen Symposion. Darbietungen, Spiele und Wettkämpfe von homerischer bis in spätklassische Zeit, Mainz.

Schäfer, Martin (2002), Zwischen Adelsethos und Demokratie. Archäologische Quellen zu den Hippeis im archaischen und klassischen Athen, Munich.

Schäfer, Thomas (1996), “Dikelia, Terma und Tettix: Zur Palästritenstele von Sunion,” MDAI(A) 111, 109-140.

Schaps, David (1977), “The Woman Least Mentioned: Etiquette and Women's Names,” CQ 27, 323-330.

Schauenburg, Konrad (1965), "Erastes und Eromenos auf einer Schale des Sokles," AA, 849-867.

Schauenburg, Konrad (1971), "Herakles und die Hydra auf attischem Schalenfuss," AA, 162-178.

Schauenburg, Konrad (1973), "Silene beim Symposion," JDAI 88, 1-26.

Schauenburg, Konrad (1976), "Erotenspiele I," AW7, 39-52.

Schauenburg, Konrad (1978), "Zwei seltene mythologische Bilder auf einer Amphora in Privatbesitz," in Gerda Schwarz/Erwin Pochmarski (eds.), Classica et Provincialia. Festschrift Erna Diez, Graz, 169-176.

Schauenburg, Konrad (1979), “Herakles Musikos," JDAl 94, 49-76.

Schauenburg, Konrad (1989), "Herakles bei Atlas," AA, 23-32.

Schauenburg, Konrad (1999), "Neue Zirkusbilder," in Nicole Blanc/André Buissons (eds.), Imago Antiquitatis: Religions et iconographie du monde roman. Mélanges offerts à Robert Turcan, Paris 1999, 395-402.

Schauenburg, Konrad (2001), Studien zur unteritalischen Vasenmalerei, Vol. 3, Kiel.

Schefold, Karl (1934), Untersuchungen zu den Kertscher Vasen, Archäologische Mitteilungen aus russischen Sammlungen 4, Berlin.

Schefold, Karl (1978), Götter- und Heldensagen der Griechen in der spätarchaischen Kunst, Munich.

Schefold, Karl (1981), Die Göttersage in der klassischen und hellenistischen Kunst, Munich.

Schefold, Karl (1992), Gods and Heroes in Late Archaic Greek Art, Cambridge. 
Schefold, Karl/Jung, Franz (1988), Die Urkönige, Perseus, Bellerophon, Herakles und Theseus in der klassischen und hellenistischen Kunst, Munich.

Schefold, Karl/Jung, Franz (1989), Die Sagen von den Argonauten, von Theben und Troia in der klassischen und hellenistischen Kunst, Munich.

Schefold, Karl et al. (1993), Götter- und Heldensagen der Griechen in der früh- und hocharchaischen Kunst, Munich.

Scheibler, Ingeborg (1995), Griechische Töpferkunst. Herstellung. Handel und Gebrauch der antiken Tongefäße, $2^{\text {nd }}$ edn., Munich.

Scheibler, Ingeborg (2000), “Attische Skyphoi für attische Feste," AK 43, 17-43.

Schlesier, Renate (ed.) (2011), A Different God? Dionysos and Ancient Polytheism, Berlin.

Schmid, Stephan G. (2006), Boire pour Apollon. Céramique hellénistique et banquets dans le sanctuaire d'Apollon Daphnéphoros, Eretria 16, Gollion.

Schmidlin, Clemens (2006), "Verlust der Flotte - Odysseus rettet sein Leben," in Raimund Wünsche (ed.), Mythos Troja, Ausstellungskatalog Staatliche Antikensammlungen und Glyptothek München, Munich, 360-367.

Schmidt, Margot (1968), Der Basler Medeasarkophag: Ein Meisterwerk spätantoninischer Kunst, Tübingen.

Schmidt, Margot (2000), "Review of Luca Giuliani, Tragik, Trauer und Trost. Bildervasen für eine apulische Totenfeier, Hannover 1995," Gnomon 72, 438-443.

Schmidt, Max (1917), Troika. Archäologische Beitrage zu den Epen des troischen Sagenkreises, Göttingen.

Schmidt, Ricarda (2010), “Mädchen im Heiligtum. Die Arrhephoren auf der Akropolis im Hellenismus und in der Kaiserzeit," in Ralf Krumeich/Christian Witschel (eds.), Die Akropolis von Athen im Hellenismus und in der römischen Kaiserzeit, Wiesbaden, 219-232.

Schmidt, Stefan (2005), Rhetorische Bilder auf attischen Vasen: Visuelle Kommunikation im 5. Jahrhundert v. Chr., Berlin.

Schmitt Pantel, Pauline (1992), La cité au banquet. Histoire des repas publics dans les cités grecques, Collection de l'Ecole Française de Rome 157, Rome.

Schmitt, Johanna (1921), Freiwilliger Opfertod bei Euripides, Rel. Vers. u. Vorarb. Bd. 17.2, Giessen.

Schnapp, Alain (1989), “Eros the Hunter," in Claude Bérard et al. (eds.), A City of Images: Iconography and Society in Ancient Greece, trans. by Deborah Lyons, Princeton, 71-87.

Schnapp, Alain (1997), Le chasseur et la cité. Chasse et érotique dans la Grèce ancienne, Paris.

Schneider, Lambert (2010), “Kirkes Weg," in Dieter Metzler (ed.), Mazzo di Fiori: Festschrift for Herbert Hoffmann, Ruhpolding/Mainz, 39-53.

Schneider, Rolf (1986), Bunte Barbaren: Orientalenstatuen aus farbigem Marmor in der römischen Repräsentationskunst, Worms.

Schofield, A. F. (trans.) (1958-59), Aelian. On the Characteristics of Animals, 3 vols., Cambridge, MA.

Schofield, Louise (1995), “The iconography of the Concentric Circle Group Oinochoai," in Christine

E. Morris (ed.), Klados. Essays in Honour ofJ. N. Coldstream, BICS Supplement 63, London, 239-247.

Schöne, Angelika (1987), Der Thiasos: Eine ikonographische Untersuchung über das Gefolge des Dionysos in der attischen Vasenmalerei des 6. und 5. Jhs. v. Chr., Göteborg.

Schönert, Kristine (1997), “Urne mit Meleagermythos," in Richard Neudecker/Maria Grazia Granino Cecere/Annetta Alexandridis (eds.), Antike Skulpturen und Inschriften im Institutum Archaeologicum Germanicum, Wiesbaden, 85-87.

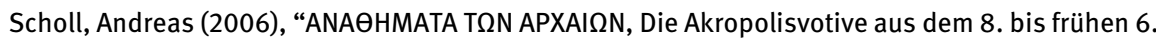
Jahrhunderts v. Chr. und die Staatswerdung Athens," JDAl 121, 1-173.

Schwarz, Gerda (1984), "Review of Christiane Sourvinou-Inwood, Theseus as Son and Stepson. A Tentative Illustration of Greek Mythological Mentality, London 1979," GB 11, 283-286. 
Schweitzer, Bernhard (1941), “Krieger in der Grabkunst des fünften Jahrhunderts,” Die Antike 17, 35-48.

Schweitzer, Bernhard (1971), Greek Geometric Art, London.

Scodel, Ruth (1996), “ $\Delta$ ó $\mu \omega v$ ớ $\alpha \lambda \mu \alpha$ : Virgin Sacrifice and Aesthetic Object,” TAPhA 126, 111-128.

Seaford, Richard (1984), Cyclops, Oxford.

Seaford, Richard (2006), Dionysos, London/New York.

Servadei, Cristina (2005), La figura di Theseus nella ceramica Attica. Iconografia e iconologia del mito nell'Atene arcaica e classica, Bologna.

Sestieri, P. C. (Pellegrino Claudio) (1955), “Il sacello-heroon Posidoniate,” BA 40, 53-64.

Sevinç, Nurten (1996), “A New Sarcophagus of Polyxena from the Salvage Excavations at Gümüsçay,” Studia Troica 6, 251-264.

Shapiro, H. A. (H. Alan) (1980), “Jason's Cloak,” TAPhA 110, 263-286.

Shapiro, H. A. (H. Alan) (1981a), Art, Myth, and Culture. Greek Vases from Southern Collections, Exhibition Catalogue, New Orleans Museum of Art and Tulane University, New Orleans.

Shapiro, H. A. (H. Alan) (1981b), “Courtship Scenes in Attic Vase-Painting," AJA 85, 133-143.

Shapiro, H. A. (H. Alan) (1982), "Theseus, Athens, and Troizen,” AA, 291-297.

Shapiro, H. A. (H. Alan) (1984), "Herakles and Kyknos," AJA 88, 523-529.

Shapiro, H. A. (H. Alan) (1989), Art and Cult under the Tyrants in Athens, Mainz.

Shapiro, H. A. (H. Alan) (1990a), "Comings and Goings: The Iconography of Departure and Arrival on Attic Vases," Métis 5, 113-124.

Shapiro, H. A. (H. Alan) (1990b), "The Eye of the Beholder: Würzburg 309 Again,” AK 33, 83-92.

Shapiro, H. A. (H. Alan) (1990c), “Old and New Heroes: Narrative, Composition and Subject in Attic Black-Figure," ClAnt 9, 114-148.

Shapiro, H. A. (H. Alan) (1991), "The Iconography of Mourning in Athenian Art," AJA 95, 629-656.

Shapiro, H. A. (H. Alan) (1992a), "Eros in Love: Pederasty and Pornography in Greece,” in Amy Richlin (ed.), Pornography and Representation in Greece and Rome, 0xford, 53-72.

Shapiro, H. A. (H. Alan) (1992b), “Mousikoi Agones: Music and Poetry at the Panathenaia,” in Jenifer Neils (ed.), Goddess and Polis. The Panathenaic Festival in Ancient Athens, Princeton, 53-75.

Shapiro, H. A. (H. Alan) (1992c), "Narrative Strategies in Euphronios," in Mario Cygielman et al. (eds.), Euphronios, Atti del Seminario internazionale di studi, Arezzo, 27-28 maggio 1990, Florence, 37-43.

Shapiro, H. A. (H. Alan) (1993a), "Hipparchos and the Rhapsodes,” in Carol Dougherty/Leslie Kurke (eds.), Cultural Poetics in Archaic Greece: Cult, Performance, Politics, Cambridge, 92-107.

Shapiro, H. A. (H. Alan) (1993b), Personifications in Greek Art: The Representation of Abstract Concepts 600-400 B.C., Akanthus crescens 1, Kilchberg/Zurich.

Shapiro, H. A. (H. Alan) (1994a), Myth Into Art: Poet and Painter in Classical Greece, London/ New York.

Shapiro, H. A. (H. Alan) (1994b), "Religion and Politics in Democratic Athens," in William D. E. Coulson et al. (eds.), The Archaeology of Athens and Attica under the Democracy, Proceedings of an International Conference Celebrating 2500 Years since the Birth of Democracy in Greece, held at the American School of Classical Studies at Athens, December 4-6, 1992, Oxford, 123-129.

Shapiro, H. A. (H. Alan) (1995a), “The Cult of Heroines: Kekrops' Daughters,” in Ellen D. Reeder (ed.), Pandora. Women in Classical Greece, Baltimore, 39-48.

Shapiro, H. A. (H. Alan) (1995b), "Les rhapsodes aux Panathénées et la céramique à Athènes à l'époque archaïque,” in Annie Verbanck-Piérard/Didier Viviers (eds.), Culture et cité: L'avènement d'Athènes à l'époque archaïque, Actes du colloque international organisé à l'Université de Bruxelles, du 25 au 27 avril 1991, Brussels, 127-137.

Shapiro, H. A. (H. Alan) (1996), “Cults of Solonian Athens,” in Robin Hägg (ed.), The Role of Religion in the Early Greek Polis, Proceedings of the Third International Seminar on Ancient Greek Cult, organized by the Swedish Institute at Athens, 16-18 October 1992, Stockholm, 127-133. 
Shapiro, H. A. (H. Alan) (1997), "Correlating Shape and Subject: The Case of the Archaic Pelike," in John H. Oakley/William D. E. Coulson/Olga Palagia (eds.), Athenian Potters and Painters I, The Conference Proceedings, Oxford, 63-70.

Shapiro, H. A. (H. Alan) (2000), "Leagros and Euphronios: Painting Pederasty in Athens," in Thomas K. Hubbard (ed.), Greek Love Reconsidered, New York, 12-32.

Shapiro, H. A. (H. Alan) (2001), "Red-Figure Panathenaic Amphoras: Some Iconographical Problems," in Martin Bentz/Norbert Eschbach (eds.), Panathenaïka. Symposion zu den Panathenäischen Preisamphoren, Rauischholzhausen 25.11.-29.11.1998, Mainz, 119-124.

Shapiro, H. A. (H. Alan) (2004), "Leagros the Satyr," in Clemente Marconi (ed.), Greek Vases: Images, Contexts and Controversies, Proceedings of the Conference sponsored by the Center for the Ancient Mediterranean at Columbia University, 23-24 March 2002, Leiden, 1-12.

Shapiro, H. A. (H. Alan) (2008), "Cults of Heroines in ancient Athens," in Nikolaos Kaltsas/H. A. (H. Alan) Shapiro (eds.), Worshiping Women: Ritual and Reality in Classical Athens, New York, 163-173.

Shapiro, H. A. (H. Alan) (2009a), “Alcibiades: The Politics of Personal Style," in Olga Palagia (ed.), Art in Athens during the Peloponnesian War, Cambridge, 236-263.

Shapiro, H. A. (H. Alan) (2009b), "Topographies of Cult and Athenian Civic Identity on Two Masterpieces of Attic Red-figure," in John H. Oakley/Olga Palagia (eds.), Athenian Potters and Painters II, The Conference Proceedings, Oxford/Oakville, 261-269.

Shapiro, H. A. (H. Alan) (2010), “Mother and Son. Theseus's Farewell to Aithra," in Carina Weiss/Erika Simon (eds.), Folia in memoriam Ruth Lindner collecta, Dettelbach, 89-94.

Shapiro, H. A. (H. Alan) (2012a), "Attic Heroes and the Construction of the Athenian Past in the Fifth Century," in John Marincola/Lloyd Llewellyn-Jones/Calum Maciver (eds.), Greek Notions of the Past in the Archaic and Classical Eras. History without Historians, Edinburgh, 160-183.

Shapiro, H. A. (H. Alan) (2012b), Re-fashioning Anakreon in Classical Athens, Morphomata Lectures Cologne 2, Munich.

Shapiro, H. A. (H. Alan)/lozzo, Mario/Lezzi-Hafter, Adrienne (eds.) (2013), The François Vase. New Perspectives, Papers of the International Symposium, Villa Spelman, Florence, 23-24 May 2003, 2 vols., Kilchberg/Zurich.

Shear, Julia L. (2001), Polis and the Panathenaia: The History and Development of Athena's Festival, Ph.D. Diss., University of Pennsylvania.

Shear, Julia L. (2003), "Prizes from Athens: The List of Panathenaic Prizes and the Sacred Oil," ZPE 142, 87-108.

Shear, T. Leslie (1973), “The Athenian Agora. Excavations of 1971,” Hesperia 42, 121-179.

Shefton, Brian B. (1982), “The Krater from Baksy,” in Donna C. Kurtz/Brian A. Sparkes (eds.), The Eye of Greece. Studies in the Art of Athens, Cambridge, 149-181.

Shefton, Brian B. (1998), "Metal and Clay. Prototype and Re-creation. Zoffany's 'Tribuna' and Lessons from the Malacena Fabric of Hellenistic Volterra. Calyx-krater, Stamnos, Situla, and the Achaemenid Rhyton," REA 100, 619-662.

Sichtermann, Helmut (1970), "Beiträge zu den Meerwesensarkophagen,” AA, 214-241.

Sifakis, Gregory M. (1967), "Singing Dolphin Riders," BICS 14, 36-37.

Simantoni-Bournia, Eva (2004), La céramique grecque à reliefs. Ateliers insulaires du VIIle au Vie siècle avant J.-C., Geneva.

Simon, Erika (1967), Ara Pacis Augustae, Tübingen.

Simon, Erika (1970), Meleager und Atalante: Ein spätantiker Wandbehang, Bern.

Simon, Erika (1976), Die griechischen Vasen. Aufnahmen von Max und Albert Hirmer. Munich.

Simon, Erika (1985), "Early Classical Vase-Painting," in Cedric G. Boulter (ed.), Greek Art: Archaic into Classical, A Symposium Held at the University of Cincinnati, April 2-3, 1982, Leiden, 66-82. 
Simon, Erika (2004), “Aias mit der Leiche Achills," NAC 33, 29-38.

Simon, Erika (2012), Ausgewählte Schriften IV, Ruhpolding/Mainz.

Simon, Erika (2013), "Greek Myth in Etruscan Culture," in Jean MacIntosch Turfa (ed.), The Etruscan World, London/New York, 495-512.

Simon, Erika/Kathariou, Kleopatra (2005), "Weinlesefest und Theseia. Eine Kylix in deutschem Privatbesitz," NAC 34, 73-91.

Sini, Thalia (1997), "A Symposion Scene on an Attic Fourth-century Calyx-krater in St. Petersburg," in Olga Palagia (ed.), Greek Offerings. Essays on Greek art in Honour of John Boardman, Oxford, 159-165.

Sinn, Friederike (1987), Stadtrömische Marmorurnen, Beiträge zur Erschließung hellenistischer und kaiserzeitlicher Skulptur und Architektur 8, Mainz.

Sinn, Friederike (2006), Reliefgeschmückte Gattungen römischer Lebenskultur. Vatikanische Museen, Museo Gregoriano Profano. Katalog der Skulpturen III, Wiesbaden.

Skafte Jensen, Minna (2011), Writing Homer. A Study Based on Results from Modern Fieldwork, Scientia Danica, Series H: Humanistica 8.4, Copenhagen.

Slater, William J. (1976), "Symposium at Sea," HSPh 80, 161-170.

Slatkin, Laura (1991), The Power of Thetis: Allusion and Interpretation in the lliad, Berkeley.

Smith, H. R. W. (1945), "From Farthest West," AJA 49, 465-479.

Smith, H. R. W. (1974), Der Lewismaler (Polygnotos II), reprint [1939], Mainz.

Smith, R. R. R. (1987), “The Imperial Reliefs from the Sebasteion at Aphrodisias,” JRS 77, 88-138.

Smith, R. R. R. (1988), "Simulacra Gentium: The Ethne from the Sebasteion at Aphrodisias," JRS 78, 50-77.

Smith, R. R. R. (1990), “Myth and Allegory in the Sebasteion," in Charlotte Roueché/Kenan T. Erim (eds.), Aphrodisias Papers: Recent Work on Architecture and Sculpture 1, Ann Arbor, 89-100.

Smith, R. R. R. (1993), The Monument of C. Julius Zoilos, Mainz.

Smith, R. R. R. (2007), “Pindar, Athletes, and the Early Greek Statue Habit," in Simon Hornblower/ Catherine Morgan (eds.), Pindar's Poetry, Patrons, and Festivals: From Archaic Greece to the Roman Empire, Oxford, 83-139.

Smith, Rex Alan (1985), The Carving of Mt. Rushmore, New York.

Smith, Tyler Jo (1998), "Dances, Drinks and Dedications: The Archaic Komos in Laconia," in Sparta in Laconia, Proceedings of the 19th British Museum Classical Colloquium, London 6-8 December 1995. British School at Athens Studies vol. 4, Athens/London, 75-81.

Smith, Tyler Jo (2004), "Black-figure Column Krater ca. 510-500 BC," in Andrea N. Douglas (ed.), The Museum: Conditions and Space, Selections from the University of Virginia Art Museum, Charlottesville, 76-77.

Smith, Tyler Jo (2010), Komast Dancers in Archaic Greek Art, Oxford.

Smyth, Herbert Weir (trans.) (1926), Aeschylus. Agamemnon. Choephoroi. Eumenides. Fragments, 2 vols., Cambridge, MA.

Snodgrass, Anthony (1998), Homer and the Artists: Text and Picture in Early Greek Art, Cambridge.

Snodgrass, Anthony (2006), "Pausanias and the Chest of Kypselos," in Anthony Snodgrass (ed.), Archaeology and the Emergence of Greece: Collected Papers on Early Greece and Related Topics (1965-2002), Ithaca, NY, 422-445.

Soldi, Sebastiano (2012), “'Chimaeric Animals' in the Ancient Near East,” in G. Carlotta Cianferoni/ Mario lozzo/Elisabetta Setari (eds.), Myth, Allegory, Emblem: The Many Lives of the Chimaera of Arezzo, Proceedings of the International Colloquium, Malibu, The J. Paul Getty Museum (December 4-5, 2009), Rome, 91-112.

Söldner, Magdalene (2011), “Das Naiskosbild. Ikonographie und Deutung,” in Konrad Hitzl (ed.), Kerameia. Ein Meisterwerk apulischer Töpferkunst. Studien dem Andenken Konrad Schauenburg Gewidmet, Kiel, 108-123. 
Solley, Thomas T. (1980), Guide to the Collections. Highlights from the University of Indiana Art Museum, Bloomington.

Sommerstein, Alan H. (2008), Aeschylus. Fragments, Cambridge, MA.

Sotheby's London (1988), Antiquities, Auction Catalogue 12, December, London.

Sourvinou-Inwood, Christiane (1979), Theseus as Son and Stepson. A Tentative Illustration of Greek Mythological Mentality, BICS Supplement 40, London.

Sourvinou-Inwood, Christiane (1987), "Menace and Pursuit: Differentiation and the Creation of Meaning," in Claude Bérard/Christiane Bron/Alessandra Pomari (eds.), Images et société en Grèce ancienne: L'iconographie comme méthode d'analyse, Actes du Colloque international Lausanne, 8-11 février, 1984, Lausanne, 41-58.

Sourvinou-Inwood, Christiane (1990), "Myths in Images. Theseus and Medea as a Case Study," in Lowel Edmunds (ed.), Approaches to Greek Myth, Baltimore, 395-445.

Sourvinou-Inwood, Christiane (1995), 'Reading' Greek Death to the End of the Classical Period, Oxford.

Sourvinou-Inwood, Christiane (2005), Hylas, the Nymphs, Dionysos, and Others: Myth, Ritual, Ethnicity, Skrifter utgivna av Svenska institutet i Athen $8^{\circ}$, Stockholm.

Sourvinou-Inwood, Christiane (2008), “A Reading of Two Fragments of Sophilos,” JHS 128, 128-131.

Sowder, Amy (2009), Greek Bronze Hydriai, Ph.D. Diss., Emory University.

Spantidaki, Youlie/Moulherat, Christophe (2012), “Greece,” in Margarita Gleba/Ulla Mannering (eds.), Textiles and Textile Production in Europe from Prehistory to AD 400, 0xford, 185-200.

Sparkes, Brian A./Talcott, Lucy (1970), Black and Plain Pottery of the $6^{\text {th }}, 5^{\text {th }}$ and $4^{\text {th }}$ centuries B.C., 2 vols., The Athenian Agora 12, Princeton.

Sparkes, Brian A. (1976), "Treading the Grapes," BABesch 51, 47-64.

Spier, Jeffrey (2000), "From East Greece to Etruria: A Late Sixth-Century BC Gem Workshop," in Gocha R. Tsetskhladze/A. J. N. W. Prag/Anthony Snodgrass (eds.), Periplous: Papers on Classical Art and Archaeology Presented to Sir John Boardman, London/New York, 330-335.

Spurling, John/Bryant, Julius (1994), The Trojan War: Sculptures by Anthony Caro, London.

Stadter, Philip A. (2004), "From the Mythical to the Historical Paradigm: The Transformation of Myth in Herodotus," in José Maria Candau Morón/Francisco J. González Ponce/Gonzalo Cruz Andreotti (eds.), Historia y Mito: El pasado legendario como fuente de autoridad, Malaga, 31-46.

Stafford, Emma (2012), Herakles. Gods and Heroes of the Ancient World, New York.

Stähler, Klaus (1976), “Zur Reiterkampfgruppe in Boston," AA, 58-72.

Stahl, Michael (1987), Aristokraten und Tyrannen im archaïschen Athen. Untersuchungen zur Überlieferung, zur Sozialstruktur und zur Entstehung des Staates, Stuttgart.

Stahl, Michael (2003), Gesellschaft und Staat bei den Griechen: Archaische Zeit, Paderborn.

Stampolidis, Nicholas/Tassoulas, Yorgos (eds.) (2009), Eros: From Hesiod's Theogony to Late Antiquity, Athens.

Stansbury-O’Donnell, Mark D. (1999), Pictorial Narrative in Ancient Greek Art, Cambridge.

Stauffer, Annemarie (1991), Textiles d'Égypte de la Collection Bouvier: Antiquité tardive, période copte, premiers temps de l'Islam, Bern.

Stears, Karen (1998), “Death Becomes Her: Gender and Athenian Death Ritual,” in Sue Blundell/ Margaret Williamson (eds.), The Sacred and the Feminine in Ancient Greece, London/New York, 113-127.

Steger, Florian (2005), “Wasser erfassen - Wasser wahrnehmen. Religiöse, soziale und medizinische Funktionen des Wassers: Kult und Medizin des Asklepios," in Sylvelyn Hähner-Rombach (ed.), "Ohne Wasser ist kein Heil." Medizinische und kulturelle Aspekte der Nutzung von Wasser, Stuttgart, 33-44.

Stehle, Eva (1997), Performance and Gender in Ancient Greece: Nondramatic Poetry in its Setting, Princeton. 
Steiner, Ann (2007), Reading Greek Vases, Cambridge.

Steingräber, Stephan (1986), Etruscan Wall Painting, Catalogue raisonné of Etruscan wall painting, New York.

Steingräber, Stephan (2006), Abundance of Life. Etruscan Wall Painting, trans. by Russel Stockman, Los Angeles.

Steinhart, Matthias (2004), Die Kunst der Nachahmung. Darstellungen mimetischer Vorführungen in der griechischen Bildkunst archaischer und klasssischer Zeit, Mainz.

Stewart, Andrew F. (1993), Faces of Power. Alexander's Image and Hellenistic Politics, Berkeley.

Stewart, Andrew F. (2008a), “The Persian and Carthaginian Invasions of 480 B.C.E. and the Beginning of the Classical Style: Part 1, The Stratigraphy, Chronology, and Significance of the Acropolis Deposits," AJA 112, 377-412.

Stewart, Andrew F. (2008b), “The Persian and Carthaginian Invasions of 480 B.C.E. and the Beginning of the Classical Style: Part 2, The Finds from Other Sites in Athens, Attica, Elsewhere in Greece, and on Sicily; Part 3, The Severe Style: Motivations and Meaning," AJA 112, 581-615.

Stewart, George R. (1945), Names on the Land: A Historical Account of Place-naming in the United States, New York.

Stibbe, Conrad M. (1972), Lakonische Vasenmaler des sechsten Jahrhunderts v. Chr., Studies in Ancient Civilisation 1, Amsterdam.

Stibbe, Conrad M. (1991), “Dionysos in Sparta," BABesch 66, 1-44.

Stibbe, Conrad M. (1996), Das andere Sparta, Mainz.

Stibbe, Conrad M. (2000), “Gitiadas und der krater von Vix," BABesch 75, 65-114.

Stibbe, Conrad M. (2003), Trebenishte. The Fortunes of an Unusual Excavation, Rome.

Stibbe, Conrad M. (2004), Lakonische Vasenmaler des sechsten Jahrhunderts v. Chr. Supplement, Mainz.

Stibbe, Conrad M. (2006), “The Krater from Vix Again. A Review Article," in Conrad Stibbe, Agalmata. Studien zur griechisch-archaischen Bronzekunst, BABesch Supplement 11, Leuven, 310-322.

Stilp, Florian (2006), Die Jacobsthal-Reliefs: Konturierte Tonreliefs aus dem Griechenland der Frühklassik, Rome.

Storey, Ian C. (2005), "But Comedy has Satyrs too," in George W. M. Harrison (ed.), Satyr Drama: Tragedy at Play, Swansea, 201-218.

Strauss, Barry (1993), Fathers and Sons in Athens. Ideology and Society in the Era of the Peloponnesian War, London.

Strauss, Barry (2006), The Trojan War: A New History, London/New York.

Strawczynski, Nina (2003), “Artémis et Thésée sur le skyphos du Peintre de Brygos Louvre G 195," RA 1, 3-24.

Strong, Donald (1966), Greek and Roman Gold and Silver Plate, London.

Stupperich, Reinhard (1977), Staatsbegräbnis und Privatgrabmal im klassischen Athen, Ph.D. Diss., Universität zu Münster.

Stupperich, Reinhard (1994), "The Iconography of Athenian State Burials in the Classical Period," in William D. E. Coulson et al. (eds.), The Archaeology of Athens and Attica Under the Democracy, Proceedings of an International Conference Celebrating 2500 Years since the Birth of Democracy in Greece, held at the American School of Classical Studies at Athens, December 4-6, 1992, Oxford, 93-103.

Surtees, Allison (2011), The Pouring Satyr: Copies and Context in Greece and Rome, Ph.D. Diss. The Johns Hopkins University.

Sutton, Dana F. (1980), The Greek Satyr Play, Meisenheim.

Sutton, Robert F. (2000), "The Good, the Base, and the Ugly: The Drunken Orgy in Athenian Vase Painting and the Athenian Self," in Beth Cohen (ed.), Not the Classical Ideal. Athens and the Construction of the Other in Greek Art, Leiden, 180-202. 
Sutton, Robert F. (2009), “Lovemaking on Attic Black-figure Pottery: Corpus with Some Conclusions," in Stefan Schmidt/John H. Oakley (eds.), Hermeneutik der Bilder. Beiträge zur Ikonographie und Interpretation griechischer Vasenmalerei, Munich, 77-91.

Syme, Ronald (1978), History in Ovid, Oxford.

Taplin, Oliver (2007), Pots \& Plays: Interactions between Tragedy and Greek Vase-painting of the Fourth Century B.C., Los Angeles.

Taplin, Oliver (2012), “How was Athenian Tragedy Played in the Greek West?,” in Kathryn Bosher (ed.), Theater Outside Athens: Drama in Greek Sicily and South Italy, Cambridge, 226-250.

Terzan, Biba (2011), "Horses and Cauldrons. Some Remarks on Horse and Chariot Races in Situla Art," Notizie Archeologiche Bergomensi 19, 303-325.

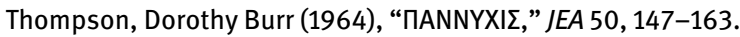

Thompson, Dorothy Burr (1984), “Quae saga; Quis magus?,” in Nicola Bonacasa/Antonino Di Vita (eds.), Alessandria e il mondo ellenistico-romano. Studi in onore di Achille Adriani, Vol. 2, Rome, 309-317.

Thompson, Homer A. (1947), "The Excavation of the Athenian Agora, 1940-46," Hesperia 16, 193-213. Thompson, Homer A. (1948), "The Excavation of the Athenian Agora, Twelfth Season: 1947," Hesperia $17,149-196$.

Thompson, Homer A. (1952), “Excavations in the Athenian Agora: 1951," Hesperia 21, 83-113. Thompson, Homer A. (1953), “Excavations in the Athenian Agora: 1952," Hesperia 22, 25-56. Thompson, Homer A. (1954), "Excavations in the Athenian Agora: 1953," Hesperia 23, 31-67. Thompson, Homer A. (1958), "Activities in the Athenian Agora: 1957," Hesperia 27, 145-160. Thompson, Homer A. (1959), “Activities in the Athenian Agora: 1958," Hesperia 28, 91-108. Thompson, Homer A. (1968), "Activity in the Athenian Agora: 1966-1967," Hesperia 37, 36-72. Thompson, Homer A./Wycherley, R. E. (1972), The Agora of Athens. The History, Shape, and Uses of an Ancient City Center, The Athenian Agora 14, Princeton.

Thompson, Norma (1996), Herodotus and the Origins of the Political Community: Arion's Leap, New Haven.

Thompson, Wesley (1982), “Weaving: A Man's Work," CW75, 217-222.

Thomsen, Arne (2011), Die Wirkung der Götter. Bilder mit Flügelfiguren aufgriechischen Vasen des 6. und 5. Jahrhunderts v. Chr., Berlin.

Thöne, Cornelia (1999), Ikonographische Studien zu Nike im 5. Jahrhundert v. Chr. Untersuchungen zur Wirkungsweise und Wesensart, Heidelberg.

Tighe, Joan (1962), “Lyons House, Celbridge Co. Kildare,” The Irish Tatler and Sketch 71.6, March 1962, 1-4.

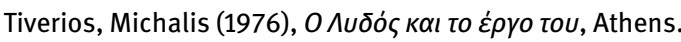

Tiverios, Michalis (2005), “Der Streit um das attische Land. Götter, Heroen und die historische Wirklichkeit," in Volker Michael Strocka (ed.), Meisterwerke. Internationales Symposion anläßlich des 150. Geburtstages von Adolph Furtwängler, Freiburg im Breisgau 30, Juni-3. Juli 2003, Munich, 299-319.

Tiverios, Michalis (2007), “Panathenaic Amphoras,” in Olga Palagia/Alkestis Choremi-Spetsieri (eds.), The Panathenaic Games, Proceedings of an International Conference held at the University of Athens, May 11-12, 2004, Oxford, 1-19.

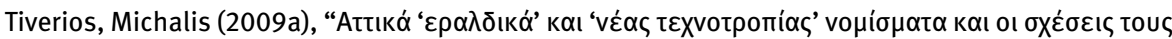

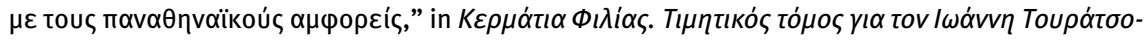
$\gamma \lambda$ iou, Athens, 55-67.

Tiverios, Michalis (2009b), "Bild und Geschichte," in Dimitrios Yatromanolakis (ed.), An Archaeology of Representations. Ancient Greek Vase-painting and Contemporary Methodologies, Athens, 159-199.

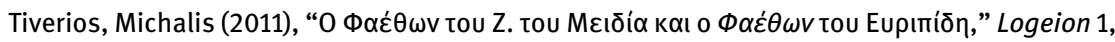
72-110. 
Tocco Sciarelli, Giuliana (1979), "L’attività archeologica nelle provincie di Napoli e Caserta," in Gli Eubei in Occidente, Atti del XVII Convegno di studi sulla Magna Grecia, Taranto 8-12 ottobre 1978, Taranto, 261-275.

Todisco, Luigi (2012), "Myth and Tragedy: Red-figure Pottery and Verbal Communication in Central and Northern Apulia in the Later Fourth Century BC," trans. by T. Simpson, in Kathryn Bosher (ed.), Theater Outside Athens: Drama in Greek Sicily and South Italy, Cambridge, 251-271.

Todisco, Luigi (ed.) (2003), La ceramica figurata a soggetto tragico in Magna Grecia e in Sicilia, Rome.

Tomlinson, Richard A. (1983), Epidauros. Archaeological Sites, London.

Topper, Kathryn (2009), "Primitive Life and the Construction of the Sympotic Past in Athenian Vase Painting," AJA 113, 3-26.

Topper, Kathryn (2010), "Maidens, Fillies and the Death of Medusa on a Seventh-century Pithos," JHS $130,109-119$.

Topper, Kathryn (2012), The Imagery of the Athenian Symposium, Cambridge.

Torelli, Mario (2007), Le strategie di Kleitias. Composizione e programma figurativo del vaso François, Milan.

Torelli, Mario (2009), “Conclusioni,” in Simona Fortunelli/Concetta Masseria (eds.), Ceramica attica da santuari della Grecia, della Ionia e dell'Italia, Atti convegno internazionale Perugia, 14-17 marzo 2007, Venosa, 773-780.

Touchefeu, Odette (1983), “Lecture des images mythologiques. Un exemple d'images sans texte: La mort d'Astyanax," in François Lissarrague/Françoise Thélamon (eds.), Image et céramique grecque, Actes du Colloque de Rouen, 25-26 novembre 1982, Rouen, 21-27.

Touchefeu-Meynier, Odette (1968), Thèmes odysséens dans l'art antique, Paris.

Townsend, Emily D. (1955), “A Mycenaean Chamber Tomb under the Temple of Ares," Hesperia 24, 187-219.

Townsend, Rhys F. (1995), The East Side of the Agora. The Remains beneath the Stoa of Attalos, The Athenian Agora 27, Princeton.

Trachtenberg, Marvin (1977), The Statue of Liberty, New York.

Traill, John S. (1998), Persons of Ancient Athens, Vol. 7, Toronto.

Travlos, John (1971), Pictorial Dictionary of Ancient Athens, New York.

Trendall, Arthur Dale (1938), Fruhitaliotische Vasen, Leipzig.

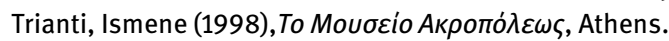

Trofimova, Anna A. (ed.) (2007), The Greeks on the Black Sea. Ancient Art from the Hermitage, Los Angeles.

Trofimova, Anna et al. (eds.) (2010), The Immortal Alexander the Great. The Myth, the Reality, his Journey, his Legacy, Amsterdam.

Trümper, Monika (2008), Die 'Agora des Italiens' in Delos. Baugeschichte, Architektur, Ausstattung und Funktion einer späthellenistischen Porticus-Anlage, Internationale Archäologie 104, 2 vols., Rahden/Westfalen.

Trümper, Monika (2009), "Complex Public Bath Buildings of the Hellenistic period. A Case-study in Regional Differences," in Marie-Françoise Boussac/Thibaud Fournet/Bérangère Redon (eds.), Le bain collectifen Egypte, Études urbaines 7, Cairo, 139-79.

Trümper, Monika (2013a), “Introduction,” in Sandra K. Lucore/Monika Trümper (eds.), Greek Baths and Bathing Culture: New Discoveries and Approaches, BABesch Supplement 23, Leuven, $1-9$.

Trümper, Monika (2013b), “Urban Context of Greek Public Baths," in Sandra K. Lucore/Monika Trümper (eds.), Greek Baths and Bathing Culture: New Discoveries and Approaches, BABesch Supplement 23, Leuven, 33-72. 
Trümper, Monika (2014a), “Greek Baths and Bathing Culture,” in Claire Smith et al. (eds.), Encyclopedia of Global Archaeology, New York.

Trümper, Monika (2014b), “Privat versus Öffentlich in hellenistischen Bädern,” in Albrecht Matthaei/ Martin Zimmermann (eds.), Stadtkultur im Hellenismus. Die hellenistische Polis als Lebensform, Vol. 4, Mainz, 204-247.

Trümper, Monika (in preparation), LACONICUM. A Reassessment of Graeco-Roman Sweat Baths from a Cross-Cultural Perspective.

Tsakirgis, Barbara (2005), "Living and Working Around the Athenian Agora. A Preliminary Case Study of Three Houses," in Bradley A. Ault/Lisa C. Nevett (eds.) (2005), Ancient Greek Houses and Households: Chronological, Regional, and Social Diversity, Philadelphia, 67-82.

Tsakirgis, Barbara (2009), “Leben rund um die Agora. Häuser und Haushalte im Zentrum Athens," in John McK. Camp/Craig A. Mauzy (eds.), Die Agora von Athen. Neue Perspektiven für eine archäologische Stätte, trans. by Alexandra Velten, Mainz, 47-54.

Tsiafakis, Despoina (2003), “"ПЕ $\wedge \Omega P A '$ : Fabulous Creatures and/or Demons of Death?,” in J. Michael Padgett (ed.), The Centaur's Smile: The Human Animal in Early Greek Art, Exhibition Catalogue, Princeton University Art Museum, Princeton, 73-104.

Tsouklidou, Despoina (2001), “New Panathenaic Amphorae of the Hellenistic period," in Martin Bentz/Norbert Eschbach (eds.), Panathenaïka. Symposion zu den Panathenäischen Preisamphoren, Rauischholzhausen 25.11.-29.11.1998, Mainz, 33-40.

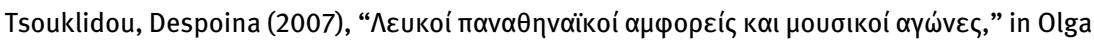
Palagia/Alkestis Choremi-Spetsieri (eds.), The Panathenaic Games, Proceedings of an International Conference held at the University of Athens, May 11-12, 2004, 0xford, 109-116.

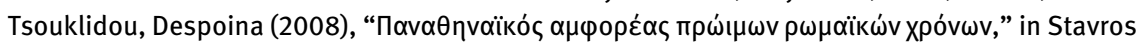
Vlizos (ed.), Athens During the Roman Period, Athens, 449-457.

Tuchelt, Klaus (1979), Frühe Denkmäler Roms in Kleinasien: Beiträge zur archäologischen Überlieferung aus der Zeit der Republik und des Augustus, Tübingen.

Tuna-Nörling, Yasemin (2001), “Polyxena bei Hektors Lösung: Zu einem attisch-rotfigurigen Krater aus Tekirdağ (Bisanthe/Rhaidestos)," AA, 27-44.

Tusa, Vincenzo (1988), “Il giovane di Mozia,” in Nicola Bonacasa/Antonino Buttitta (eds.), La statua marmorea di Mozia e la scultura di stile severo in Sicilia, Atti della giornata di studio, Marsala, 1 giugno 1986, Rome, 53-60.

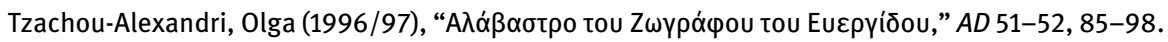

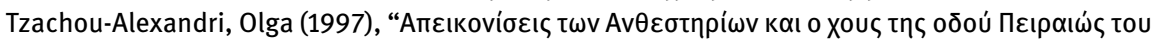

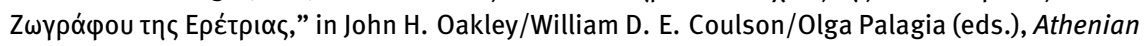
Potters and Painters I, The Conference Proceedings, Oxford/Oakville, 473-490.

Ure, Annie D. (1955), “Krokotos and White Heron," JHS 75, 90-103.

Vafopoulou-Richardson, C. E. (1981), Greek Terracottas. University of Oxford, Ashmolean Museum, Oxford.

Valavanis, Panos (1987), "Säulen, Hähne, Niken und Archonten auf Panathenäischen Preisamphoren," $A A, 467-480$.

Valavanis, Panos (1990), “La proclamation des vainqueurs aux Panathénées: À propos d’amphores panathénaïques de Praisos," BCH 114, 325-359.

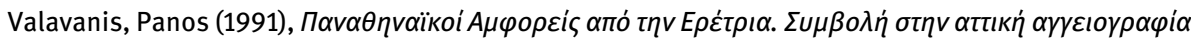
tou $4^{\text {ou }} \pi . X . \alpha$. ., Athens.

Valavanis, Panos (1999), HYSPLEX. The Starting Mechanism in Ancient Stadia: A Contribution to Ancient Greek Technology, trans. by Stephen G. Miller, Berkeley.

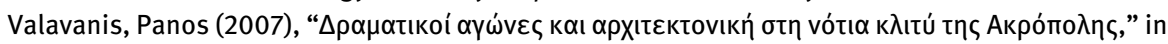
Olga Palagia/Alkestis Choremi-Spetsieri (eds.), The Panathenaic Games, Proceedings of an International Conference held at the University of Athens, May 11-12, 2004, Oxford, 127-134. 
Valavanis, Panos (2009), “Mortals Facing the Goddess: Thoughts on the Panathenaic Amphora of Lydos in Florence and Some Pseudo-Panathenaic Vases," in John H. Oakley/Olga Palagia (eds.), Athenian Potters and Painters II, The Conference Proceedings, Oxford/Oakville, 297-305.

Valavanis, Panos (2013), The Acropolis through its Museum, Athens.

Vallet, Georges/Villard, François (1955), “Un atelier de bronziers: Sur l' école du cratère de Vix," BCH 79, 50-74.

Van der Meer, Lammert Bouke (1977/78), “Etruscan Urns from Volterra. Studies on Mythological Representations I and II," BABesch 52/53, 57-131.

Van Gennep, Arnold (1960), The Rites of Passage, trans. by Monika B. Vizedom and Gabrielle L. Caffee, Chicago.

Van Hook, LaRue (1932), “On the Lacedaemonians Buried in the Kerameikos,” AJA 36, 290-292.

Van Hoorn, Gerard (1951), Choes and Anthesteria, Leiden.

Van Looy, H. (1964), Zes verloren tragedies van Euripides, Vlaamse Akad. Klasse der Letteren 51, Brussels.

Van Straten, Folkert T. (1981), “Gifts for the gods,” in Hendrik S. Versnel (ed.), Faith, Hope and Worship: Aspects of Religious Mentality in the Ancient World, Leiden, 65-151.

Varner, Eric (2004), Mutilation and Transformation: Damnatio memoriae and Roman Imperial Portraiture, Monumenta graeca et romana 10, Leiden.

Vegetti, Mario (1993), “Figure dell'animale in Aristotele," in Silvana Castiglione/Giuliana Lanata (eds.), Filosofi e animali nel mondo antico, Pisa, 123-137.

Venit, Marjorie S. (1989), "Herakles and the Hydra in Athens in the First Half of the Sixth Century B.C.," Hesperia 58, 99-113.

Verbanck-Piérard, Annie (2008), “The Colors of the Akropolis: Special Techniques for Athena," in Kenneth Lapatin (ed.), Papers on Special Techniques in Athenian Vases, Proceedings of a Symposium held in Connection with the Exhibition, Los Angeles, 47-60.

Verbanck-Piérard, Annie/Massar, Natacha/Frère, Dominique (eds.) (2008), Parfums de l'antiquité. La rose et l'encens en Méditerranée, Mariemont.

Vergados, Athanassios (2013), The “Homeric Hymn to Hermes." Introduction, Text and Commentary, Berlin.

Verger, Stéphane (2009), “La Dame de Vix. Une défunte à personalité multiple,” in Jean Guillaine (ed.), Sépultures et societés. Du néolithique à l'histoire, Paris, 285-309.

Vermeule, Cornelius C. (2001), Art and Archaeology of Antiquity I, London.

Vermeule, Emily (1979), Aspects of Death in Early Greek Art and Poetry, Berkeley.

Vermeule, Emily/Travlos, John (1966), “Mycenaean Tomb beneath the Middle Stoa,” Hesperia 35, 55-78.

Vernant, Jean-Pierre (1990), Myth and Society in Ancient Greece, trans. by Janet Lloyd, New York. Versnel, H. S. (Henk S.) (2011), Coping With the Gods. Wayward Readings in Greek Theology, Leiden. Vetta, Massimo (1979), “La giovinezza giusta di Trasibulo. Pind. Pyth. VI 48," QUCC 31, 87-90. Vickers, Michael J./Gill, David (1994), Artful Crafts. Ancient Greek Silverware and Pottery, Oxford. Vidal-Naquet, Pierre (1988), “Sophocles' Philoctetes and the Ephebia,” in Jean Pierre Vernant/Pierre Vidal-Naquet (eds.), Myth and Tragedy in Ancient Greece, trans. by Janet Lloyd, New York, 161-179.

Vidal-Naquet, Pierre/Lévêque, Pierre (1960), “Epaminondas pythagoricien ou le problème tactique de la droite et de la gauche," Historia 9, 294-308.

Vierneisel, Klaus/Kaeser, Bert (eds.) (1990), Kunst der Schale-Kultur des Trinkens, Munich.

Vocke, William F. (1970), The Athenian Heralds, Ph.D. Diss., University of Cincinnati.

Voelke, Pierre (2001), Un théâtre de la marge. Aspects figuratifs et configurationnels du drame satyrique dans l'Athènes classique, Bari.

Völcker-Janssen, Wilhelm (1993), Kunst und Gesellschaft an den Höfen Alexanders d. Gr. und seiner Nachfolger, Munich. 
Vollkommer, Rainer (ed.) (2001-2004), Künstlerlexikon der Antike, 2 vols., Munich.

von den Hoff, Ralf (2001), "Die Posen des Siegers. Die Konstruktion von Überlegenheit in attischen Theseusbildern des 5. Jahrhunderts v. Chr.," in Stefan Schmidt/Ralf von den Hoff (eds.), Konstruktionen von Wirklichkeit. Bilder im Griechenland des 5. und 4. Jahrhunderts v. Chr., Stuttgart, 73-88.

von den Hoff, Ralf (2002), "Die Pracht der Schalen und die Tatkraft des Heros. Theseuszyklen auf Symposiumsgeschirr in Athen," in Wolf-Dieter Heilmeyer et al. (eds.), Die griechische Klassik. Idee oder Wirklichkeit, Exhibition Catalogue Berlin and Bonn, Mainz, 331-337.

von den Hoff, Ralf (2009), "Herakles, Theseus and the Athenian Treasury at Delphi," in Peter Schultz/ Ralf von den Hoff (eds.), Structure, Image, Ornament: Architectural Sculpture in the Greek World, Proceedings of an International Conference Held at the American School of Classical Studies, 27-28 November 2004, Oxford, 96-104.

von den Hoff, Ralf (2010a), "Media for Theseus, or: The Different Images of the Athenian Polis-hero," in Lin Foxhall/Hans-Joachim Gehrke/Nino Luraghi (eds.), Intentional History. Spinning time in Ancient Greece, Stuttgart, 161-188.

von den Hoff, Ralf (2010b), “Theseus. Stadtgründer und Kulturheros,” in Elke Stein-Hölkeskamp/KarlJoachim Hölkeskamp (eds.), Erinnerungsorte der Antike. Die griechische Welt, Munich, 300-315.

Vulić, Nikola (1932), “Ein neues Grab bei Trebenishte,” ÖJh 27, 1-42.

Vulić, Nikola (1933a), "Neue Gräber bei Trebenishte,” AA, 459-482.

Vulić, Nikola (1933b), “Neue Gräber in Trebenishte,” Ö/h 28, 164-186.

Wachter, Rudolf (2001), Non-Attic Greek Vase Inscriptions, Oxford.

Wagner-Hasel, Beate (2002), "The Graces and Color Weaving," in Lloyd Llewellyn-Jones (ed.), Women's Dress in the Ancient Greek World, London, 17-32.

Walker, Henry J. (1994), Theseus and Athens, Oxford.

Walker, Henry J. (1995), “The Early Development of the Theseus Myth,” RhM 138, 1-33.

Walker, Susan (1983), "Women and Housing in Classical Greece. The Archaeological Evidence," in Averil Cameron/Amélie Kuhrt (eds.), Images of Women in Antiquity, London, 81-91.

Walter-Karydi, Elena (1987), Die äginetische Bildhauerschule. Werke und schriftliche Quellen, AltÄgina 2.2, Mainz.

Walter-Karydi, Elena (1994), Die Nobilitierung des Wohnhauses. Lebensform und Architektur im spätklassischen Griechenland, Xenia 35, Konstanz.

Walter-Karydi, Elena (2010), "Polygnotos' Nekyia or the Athenians and the Underworld," in Elena

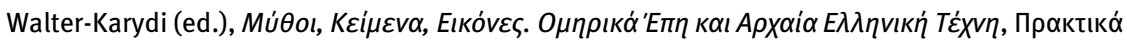

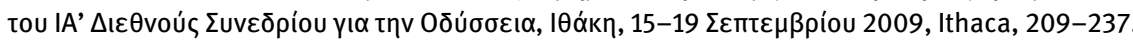

Walter, Otto (1923), Beschreibung der Reliefs im kleinen Akropolismuseum in Athen, Vienna.

Walters, Elizabeth (1988), Attic Grave Reliefs that Represent Women in the Dress of Isis, Hesperia Supplement 22, Princeton.

Walton, Marc S. et al. (2010), "Material Evidence for the Use of Attic White-Ground Lekythoi Ceramics in Cremation Burials," Journal of Archaeological Science 37, 936-940.

Warner Slane, Kathleen (2011), "Repair and Recycling in Corinth and the Archaeological Record," in Mark L. Lawall/John Lund (eds.), Pottery in the Archaeological Record: Greece and Beyond, Acts of the International Colloquium Held at the Danish and Canadian Institutes in Athens, June 2022, 2008, Aarhus, 95-106.

Watkins, Calvert (2007), "Hipponactea quaedam," in Patrick J. Finglass/Christopher Collard/N. J. (Nicholas James) Richardson (eds.), Hesperos: Studies in Ancient Greek Poetry Presented to M. L. West on his Seventieth Birthday, Oxford, 118-125.

Watrous, L. V. (L. Vance) (1982), “The Sculptural Program of the Siphnian Treasury at Delphi," AJA 86, 159-172.

Webster, T. B. L. (1967), The Tragedies of Euripides, London. 
Webster, T. B. L. (1972), Potter and Patron in Classical Athens, London.

Weill, Nicole (1959), “Céramique thasienne à figures noires,” $B C H$ 83, 430-454.

Wescoat, Bonna D. (1986), Poets \& Heroes: Scenes of the Trojan War, Exhibition Catalogue, Emory University Museum of Art and Archaeology, Michael C. Carlos Hall, November 8, 1986-February 28, 1987, Atlanta.

Wescoat, Bonna D. (2012), The Temple of Athena at Assos, Oxford.

West, M. L. (Martin L.) (1966), Hesiod: Theogony. Edited with Prolegomena and Commentary, Oxford.

West, M. L. (Martin L.) (1971-72), Iambi et Elegi Graeci, 2 vols., Oxford.

West, M. L. (Martin L.) (1974), Studies in Greek Elegy and lambus, Berlin.

West, M. L. (Martin L.) (1997), The East Face of Helicon: West Asiatic Elements in Greek Poetry and Myth, Oxford.

West, M. L. (Martin L.) (2002), “'Eumelos’: A Corinthian Epic Cycle?,” JHS 122, 109-133.

Westenholz, Joan G. (ed.) (2004), Dragons, Monsters, and Fabulous Beasts, Jerusalem.

Westgate, Ruth (1997/98), “Greek Mosaics in their Architectural and Social Context,” BICS 42, 93-115. Whitaker, Joseph I. S. (1921), Motya: A Phoenician Colony in Sicily, London.

Whitehouse, David (1998), "Review of Michael Menninger, Untersuchungen zu den Gläsern und Gipsabgüssen aus dem Fund von Begram (Afghanistan), Würzburg 1996," AJA 102, 639-641.

Wide, Sam (1893), Lakonische Kulte, Leipzig.

Wiegartz, Hans (1996), “'Simulacra gentium' auf dem Forum Transitorium,” Boreas 19, 171-179.

Wiel-Marin, Federica (2005), La ceramica attica a figure rosse di Adria. La famiglia Bocchi e l'archeologia, Padova.

Willemsen, Franz (1977), “Zu den Lakedämoniergräbern im Kerameikos,” $\operatorname{MDAI}(A)$ 92, 117-157.

Willers, Dietrich (1967), “Zum Hermes Propylaios des Alkamenes,” JDAI 82, 37-109.

Williams, Dyfri (1980), “Ajax, Odysseus and the Arms of Achilles,” AK 23, 137-145.

Williams, Dyfri (1983a), "Sophilos in the British Museum," Greek Vases in the J. Paul Getty Museum 1, Malibu, 9-34.

Williams, Dyfri (1983b), “Women on Athenian Vases: Problems of Interpretation,” in Averil Cameron/ Amelie Kuhrt (eds.), Images of Women in Antiquity, London, 92-106.

Williams, Dyfri (1991), “Onesimos and the Getty Iliupersis," Greek Vases in the J. Paul Getty Museum 5 , Occasional Papers on Antiquities 7, Malibu, 41-64.

Williams, Dyfri (1996), “Refiguring Attic Red-figure. A Review Article,” RA 2, 227-252.

Williams, Dyfri (2004), “'And Broken Vases Widowed of Their Wine’: Athenian Pottery Fragments in the Haslemere Educational Museum, Sussex," MedArch 17 (Festschrift in Honour of J. Richard Green), 105-112.

Williams, Dyfri (2007), “The Panathenaic Stadium from the Hellenistic to the Roman Period: Panathenaic Prize-amphorae and the Biel Throne," in Olga Palagia/Alkestis Choremi-Spetsieri (eds.), The Panathenaic Games, Proceedings of an International Conference held at the University of Athens, May 11-12, 2004, Oxford, 147-157.

Williams, Dyfri (2008), “Some Thoughts on the Potters and Painters of Plastic Vases before Sotades," in Kenneth Lapatin (ed.), Papers on Special Techniques in Athenian Vases, Proceedings of a Symposium held in Connection with the Exhibition, Los Angeles, 161-172.

Williams, Dyfri (2011), “Food for Thought,” Bulletin du Musée Hongrois des Beaux-Arts 114-115, 22-43.

Williams, Dyfri (2014), “An Exceptional Fourth-century Tumulus near the Piraeus,” in Panos Valavanis/

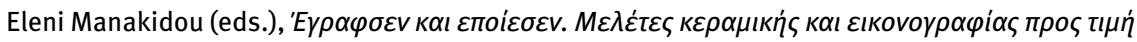

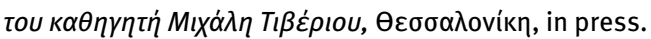

Williams, Dyfri (forthcoming), "Prometheus, Epimetheus and Pandora: From Athenian Pottery to Satyrplays and cult," Métis.

Williams, Ellen Reeder (1976), “Ancient Clay Impressions from Greek Metalwork,” Hesperia 45, 41-66. 
Williams, Ellen Reeder (1984), The Archaeological Collection of The Johns Hopkins University, Baltimore.

Winter, Irene (1985), “After the Battle is Over: The 'Stele of the Vultures' and the Beginning of Historical Narrative in the Art of the Ancient Near East," in Herbert L. Kessler/Marianna Shreve Simpson (eds.), Pictorial Narrative in Antiquity and the Middle Ages, Washington, DC, 11-32.

Wissemann, Michael (1982), Die Parther in der augusteischen Dichtung, Frankfurt.

Wolters, Paul (1890), “Funde," $\operatorname{MDAI}(A)$ 15, 346-351.

Wolters, Paul (1891), “Rotfigurige Lutrophoros,” MDAI(A) 16, 371-405.

Woodford, Susan (1993), The Trojan War in Ancient Art, Ithaca.

Woodford, Susan (2003), Images of Myths in Classical Antiquity, Cambridge.

Woodford, Susan/Loudon, Margot (1980), "Two Trojan Themes: The Iconography of Ajax Carrying the Body of Achilles and of Aeneas Carrying Anchises in Black Figure Vase Painting," AJA 84, 25-40.

Woysch-Méautis, Daphné (1982), La représentation des animaux et des êtres fabuleux sur les monuments funéraires grecs: De l'époque archaïque à la fin du IVe siècle av. J.-C., Lausanne.

Wrede, Henning (1986), Die antike Herme, Mainz.

Wulff, Oskar (1892), Zur Theseussage, Dorpat.

Wünsche, Raimund (2006a), “Achill tötet Memnon,” in Raimund Wünsche (ed.), Mythos Troja. Ausstellungskatalog Staatliche Antikensammlungen und Glyptothek München, Munich, 251-257.

Wünsche, Raimund (2006b), “Der Tod des Achill," in Raimund Wünsche (ed.), Mythos Troja, Ausstellungskatalog Staatliche Antikensammlungen und Glyptothek München, Munich, 258-269.

Wünsche, Raimund (ed.) (2003), Herakles - Herkules, Ausstellungskatalog Staatliche Antikensammlungen und Glyptothek München, Munich.

Wünsche, Raimund (ed.) (2006c), Mythos Troja, Ausstellungskatalog Staatliche Antikensammlungen und Glyptothek München, Munich.

Wünsche, Raimund/Knauss, Florian (eds.) (2004), Lockender Lorbeer: Sport und Spiel in der Antike, Ausstellungskatalog Staatliche Antikensammlungen und Glyptothek München, Munich.

Wycherley, R. E. (1957), Literary and Epigraphical Testimonia, The Athenian Agora 3, Princeton.

Yegül, Fikret (1993), “The Roman Baths at Isthmia in their Mediterranean Context," in Timothy E. Gregory (ed.), The Corinthia in the Roman Period: Including the papers given at a Symposium held at The Ohio State University on 7-9 March, 1991, JRA Supplement 8, Ann Arbor, 95-113.

Yegül, Fikret (2014), "Roman Baths at Isthmia and Sanctuary Baths in Greece," in Timothy E. Gregory/ Elizabeth Gebhard (eds.), "The Bridge of the Untiring Sea": The Corinthian Isthmus from Prehistory to Late Antiquity, Hesperia Supplement 48, Princeton, in press.

Young, Rodney S. (1949), "An Early Geometric Grave Near the Athenian Agora," Hesperia 18, 275-297.

Young, Rodney S. (1951), “An Industrial District of Ancient Athens,” Hesperia 20, 135-288.

Zanker, Paul (1965), Wandel der Hermesgestalt in der attischen Vasenmalerei, Bonn.

Zanker, Paul (2000), “Die Frauen und Kinder der Barbaren auf der Markussäule," in John Scheid/ Valérie Huet (eds.), La colonne aurélienne: Autour de la colonne aurélienne, geste et image sur la colonne de Marc Aurèle à Rome, Turnhout, 163-174.

Zanker, Paul/Ewald, Björn Christian (2004), Mit Mythen leben. Die Bilderwelt der römischen Sarkophage, Munich.

Zanoni, Ivo (1998), Natur- und Landschaftsdarstellungen in der etruskischen und unteritalischen Wandmalerei, Bern.

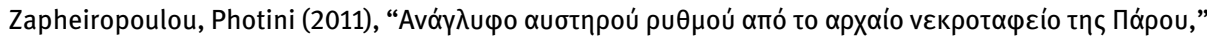
in Angelos Delivorrias/George Despinis/Angelos Zarkadas (eds.), 'Enaıvoৎ Luigi Beschi, Athens, 133-140.

Zatta, Claudia (2011), “Conflict and City-Space: Some Exempla from Thucydides' History,” ClAnt 30, 318-350.

Zazoff, Peter (1968), Etruskische Skarabäen, Mainz. 
Zeitlin, Froma I. (1996), Playing the Other: Gender and Society in Classical Greek Literature, Chicago.

Zeitlin, Froma I. (1999), "Utopia and Myth in Aristophanes' Ecclesiazousae," in Thomas M. Falkner/ Nancy Felson/David Konstan (eds.), Contextualizing Classics: Ideology, Performance, Dialogue. Essays in Honor of John J. Peradotto, Lanham, MD, 69-87.

Zevi, Fausto (1988), Unpublished entry for the exhibition Istituto Centrale per il Restauro (ed.), Il restauro dei bronzi. Fourth week of the Beni Culturali e Ambientali, December.

Zevi, Fausto (1996), “La casa di Giulio Polibio," in Maria Rosaria Borriello et al. (eds.), Pompei. Abitare sotto il Vesuvio, Exhibition Catalogue, Ferrara, 73-79.

Zhuravlev, Denis/Lomtadze, Georgiy (2007), “Ancient Vases in the State Historical Museum: History of the Collection and Some Problems of Restoration," in Martin Bentz/Ursula Kästner (eds.), Konservieren oder Restaurieren. Die Restaurierung griechischer Vasen von der Antike bis Heute, CVA Beiheft 3, Munich, 93-100.

Zimmermann, Jean-Louis (1975), “Amphore du peintre de Cléophradès,” in José Dörig (ed.), Art Antique: Collections privées de Suisse romande, Exhibition Catalogue, Geneva, no. 204.

Zimmermann, Nina (1998), Beziehungen zwischen Ton- und Metallgefässen spätklassischer und frühhellenistischer Zeit, Internationale Archäologie 20, Rahden/Westfalia.

Züchner, Wolfgang (1938), Der Berliner Mänadenkrater, Berlin.

Zwierlein-Diehl, Erika (2007), Antike Gemmen und ihr Nachleben, Berlin. 
Bereitgestellt von | De Gruyter / TCS

Angemeldet | 10.248.254.158

Heruntergeladen am | 25.08.14 07:19 